\title{
WestVirginiaUniversity
}

THE RESEARCH REPOSITORY @ WVU

Volume 105 | Issue 2

Article 5

January 2003

\section{Medical Professional Liability in West Virginia}

Thomas J. Hurney Jr.

Jackson Kelly PLLC

Rob J. Aliff Jackson Kelly PLLC

Follow this and additional works at: https://researchrepository.wvu.edu/wvlr

Part of the Medical Jurisprudence Commons

\section{Recommended Citation}

Thomas J. Hurney Jr. \& Rob J. Aliff Jackson Kelly PLLC, Medical Professional Liability in West Virginia, 105 W. Va. L. Rev. (2003).

Available at: https://researchrepository.wvu.edu/wvlr/vol105/iss2/5

This Article is brought to you for free and open access by the WVU College of Law at The Research Repository @ WVU. It has been accepted for inclusion in West Virginia Law Review by an authorized editor of The Research Repository @ WVU. For more information, please contact ian.harmon@mail.wvu.edu. 


\title{
MEDICAL PROFESSIONAL LIABILITY IN WEST VIRGINIA
}

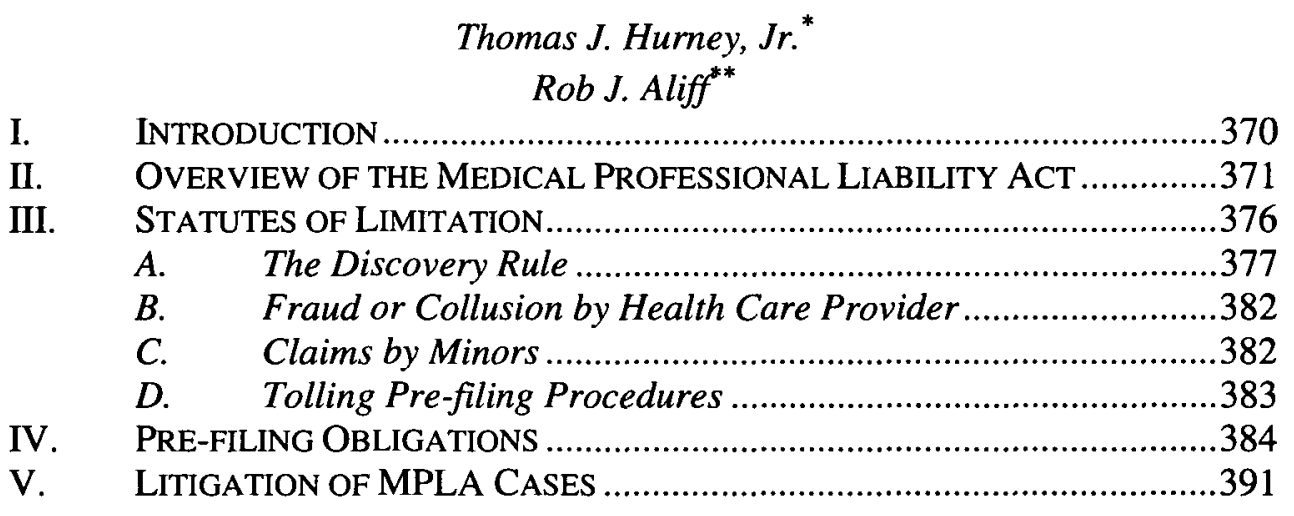

* Member, Jackson Kelly PLLC, Charleston, West Virginia. J.D., cum laude, University of Dayton School of Law, 1983. Mr. Hurney has written several articles in this journal and elsewhere related to medical professional liability issues. See Hospital Liability in West Virginia, 95 W. VA. L. Rev. 943 (1993); "A Review of the 2001 Medical Liability Enactments (HB 601)," 2002 Defense Trial Counsel of West Virginia Annual Meeting, May 31, 2002, Lakeview Resort, Morgantown, WV (speech and paper); "The Further Performance of the Medical Professional Liability Act in the Supreme Court of Appeals of West Virginia," 2002 Defense Trial Counsel of West Virginia Annual Seminar Notebook, June 2002; "2001 Medical Professional Liability Reforms: An Overview," West Virginia University/CLE Annual Litigation Seminar, February 8-9, 2002, Canaan Valley, WV (speech and paper); "Medical Professional Liability," West Virginia University/CLE Annual Litigation Seminar, January 22-23, 1999, Canaan Valley, WV (speech and paper); “The MPLA: Ten Years Later," 1997 Defense Trial Counsel of West Virginia Annual Seminar Notebook, June 1997; A Practical View of Farley v. Sartin, 99 W. VA. L. REv. 263 (1997). These articles are cited here because they discuss, in part, many of the subjects set forth in this article, and there are bound to be similarities.

\begin{abstract}
** Associate, Jackson Kelly PLLC, Charleston, West Virginia. J.D., Washington \& Lee University School of Law, 1997. Mr. Aliff has written articles and given presentations on medical professional liability and related issues. See "Obtaining Hospital Records by Subpoena: A Review of Keplinger v. Virginia Electric and Power Company," West Virginia University/CLE Annual Litigation Seminar, February 9-10, 2001, Canaan Valley, WV (speech and paper); Various Speeches and Presentations regarding "Medical Malpractice 101," "Risk Management: Preventing Malpractice Lawsuits," "Medical Record Charting," and "Health Care Directives," and "Obtaining Hospital Records by Subpoena," 2001 Defense Trial Counsel of West Virginia Annual Meeting Notebook, June 2001. These articles and presentations are cited here because they address, in part, many of the subjects set forth in this article, and some similarities are unavoidable.
\end{abstract}




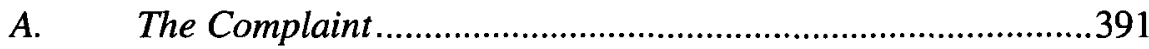

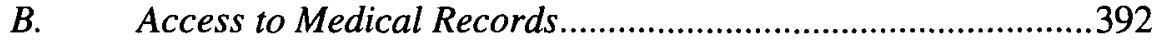

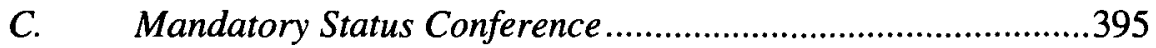

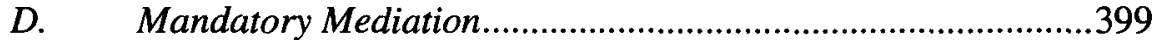

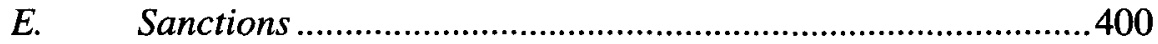

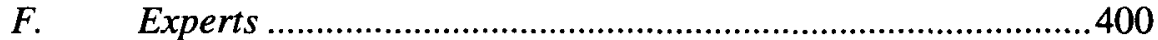

1. Necessity of Expert Testimony …..............................400

2. Expert Qualifications .................................................408

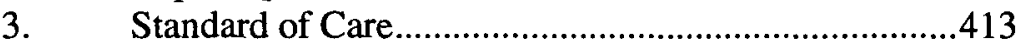

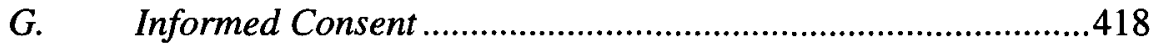

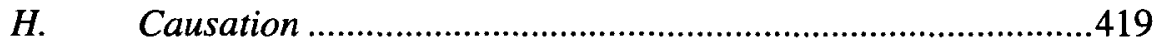

I. Summary Jury Trial...........................................................424

J. $\quad$ Assorted Trial Issues ............................................................427

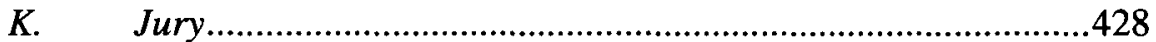

L. Comparative Fault, Joint \& Several Liability, Third Party and

Settlement Issues ........................................................................430

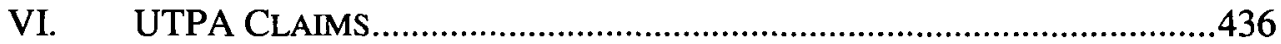

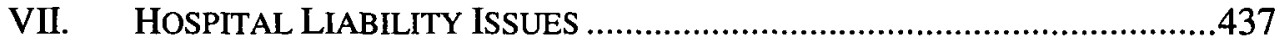

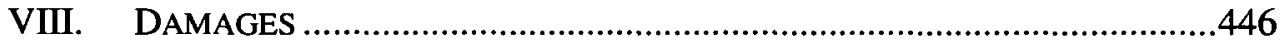

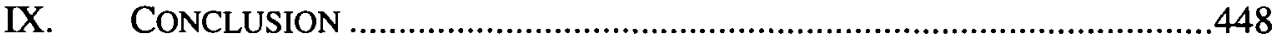

\section{INTRODUCTION}

This article is for lawyers handling medical professional liability actions in West Virginia. Navigating West Virginia law requires an awareness of legislation passed in 1986 and 2001, along with myriad decisions from the Supreme Court of Appeals of West Virginia.

On two occasions, the West Virginia Legislature passed limited civil justice reform related to medical professional liability in response to the unavailability of medical malpractice insurance. The legislature enacted the Medical Professional Liability Act ("MPLA") in 1986. ${ }^{1}$ In 2002, the legislature passed House Bill 601 ("HB 601"), which amended the MPLA and established a state insurance program for physicians not insurable in the private markets. ${ }^{2}$

Overlaying these statutes, as one would expect, are many significant cases decided by the Supreme Court of Appeals of West Virginia addressing the MPLA and numerous other issues. If history is any teacher, the ultimate state of medical professional liability law in West Virginia will probably be influenced

\footnotetext{
1 W. VA. CODE $\S \S 55-7 B-1$ to -11 (2000).
}

2 House Bill 601 amended several different provisions of the West Virginia Code. See W. VA. CODE $\$ \$ 33-20 F-1$ to -12 (Supp. 2002) (amending insurance provisions); W. VA. CODE $\$ \S$ 55-7B-1 , 5, 6, 6a, 6b, 6c, 6d, 10, 11 (amending MPLA). As of the time of the submission of this article, the West Virginia Legislature was considering additional civil justice reform. See H.B. 2122, 2003 Leg., 76th Sess. (W. Va. 2003) (passed by House on January 16, 2003). 
more by the Supreme Court of Appeals than by the legislature. ${ }^{3}$ In any event, the intent of this article is to help guide lawyers through nearly every aspect of West Virginia medical professional liability law.

\section{OVERVIEW OF THE MEDICAL PROFESSIONAL LIABILITY ACT}

The legislature, in passing the MPLA in 1986, intended to afford limited protection to health care providers and facilities - hospitals, doctors, and others - in civil actions arising from the provision of health care services. ${ }^{4}$ The MPLA was passed in the face of an insurance crisis in West Virginia which materially limited the ability of hospitals and physicians to obtain coverage. ${ }^{5}$ Generally, the MPLA, West Virginia Code sections 55-7B-1 et seq., is designed to protect health care providers and facilities in medical professional liability (medical malpractice) cases. ${ }^{6}$ The MPLA accomplished this task by defining the ele-

3 Verba v. Ghaphery, 552 S.E.2d 406 (W. Va. 2001); Robinson v. Charleston Area Med. Ctr., 414 S.E.2d 877 (W. Va. 1992). Other tort reform measures have also been held constitutional applying a rational basis analysis. Lewis v. Canaan Valley Resorts, 408 S.E.2d 634 (W. Va. 1991); see Hicks v. Ghaphery, 571 S.E.2d 317 (W. Va. 2002) (rejecting "mistake of judgment" instruction); Osborne v. United States, 567 S.E.2d 677 (W. Va. 2002) (interpreting MPLA to allow non-patients to sue physician); Bradshaw v. Soulsby, 558 S.E. 681 (W. Va. 2001) (applying "discovery rule" to wrongful death actions); Gerver v. Benavides, 530 S.E.2d 701 (W. Va. 1999) (refusing to apply "cap" to non-economic damages award); Mayhorne v. Logan Med. Found., 454 S.E.2d 87 (W. Va. 1994) (holding expert qualifications in W. VA. CoDE § 55-7B-7 (1986) unconstitutional); see also Victor E. Schwartz et al., Fostering Mutual Respect and Cooperation Between State Courts and State Legislatures: A Sound Alternative to a Tort Tug of War, 103 W. VA. L. REV. 1 (2000).

W. VA. CODE $\$ 55-7 B-1$ (2000) (noting the legislative findings and declaration of purpose).

5 This article does not attempt to wade into the dispute over tort reform, on which there are broadly conflicting views. See, e.g., U.S. Dep'T OF Health and Human SERvices, Confronting THE New Health Care Crisis: Improving Health Care Quality and Lowering Costs By FIXING OUR MEDICAL LIABILITY SYSTEM (2002), available at http://aspe.hhs.gov/search/daltcp/Reports/litrefm.pdf; Mark A. Behrens \& Cary Silverman, The Changing Landscape, 4 TORT SOURCE 1 (2002) (discussing judicial nullification of tort reform legislation); Joanne Doroshow, The Insurance Cycle [The Reform Cycle], 4 TORT SOURCE 1 (2002) (arguing liability crisis caused by mismanaged underwriting practices); Mark A. Drummond, Corporate America Grades States' Tort Systems, 27 LITIG. NEws 4 (2002) (discussing U.S. Chamber of Commerce study ranking West Virginia as one of five worst perceived states); Newt Gingrich, Commentary, USA TODAY, Aug. 13, 2002, at 15A (advocating tort reform, including medical courts).

6 "Medical professional liability actions" are defined to include "any liability for damages resulting from the death or injury of a person for any tort or breach of contract based on health care services rendered, or which should have been rendered, by a health care provider or health care facility to a patient." W. VA. CODE § 55-7B-2(d) (2000). "Health care" is "any act or treatment performed or furnished, or which should have been performed or furnished, by any health care provider for, to or on behalf of a patient during the patient's medical care, treatment or confinement." Id. §55-7B-2(a). Health care providers and facilities are defined at W. VA. CODE $\S 55-7 \mathrm{~B}-2$ (b) to $-2(\mathrm{c})$ and include doctors, nurses and hospitals, among others, as well as any "officer, employee or agent thereof acting in the course and scope of such officer's, employee's or agent 's employment." $I d . \S 55-7 \mathrm{~B}-2$ (c). Key to the definitions is the issue of licensure. Health 
ments of a medical professional liability case, limiting non-economic damages, limiting joint and several liability, establishing minimum expert requirements, and providing procedural safeguards, including protection for settling parties. ${ }^{7}$

The first consideration in evaluating an action is to determine whether the MPLA applies. This determination depends on the type of action filed, the date of injury, and the date the action is filed. The type of action is important, because the MPLA applies only to civil actions that fit within its definitions. ${ }^{8}$ The dates of injury and filing are important because they trigger different versions of the statute, either the 1986 enactment or the 2002 amendments. ${ }^{9}$

The MPLA is a definition-based statute:

The provisions of the Medical Professional Liability Act, [West Virginia] Code section 55-7B-1 to -11 (1986), govern actions falling within its parameters, subject to this Court's power to promulgate rules for all cases and proceedings, including rules of practice and procedure, pursuant to Article VIII, Section 3 of the West Virginia Constitution. ${ }^{10}$

When the facts underlying a cause of action fit within the definitions, the MPLA applies; conversely, when they do not, the MPLA does not apply.

The MPLA applies to "any liability for damages resulting from the death or injury of a person for any tort or breach of contract based on health care services rendered, or which should have been rendered, by a health care provider or health care facility to a patient."11 Generally, the statute codifies the traditional health care provider and patient relationship as the basis for actions claiming professional negligence. ${ }^{12}$ The statute defines patients, ${ }^{13}$ health care

care providers must be "licensed by, or certified in, this state or another state, to provide health care or professional health care services." Id. Health care facilities-hospitals, nursing homes or extended care facilities - include those "in and licensed by the state of West Virginia and any state operated institution or clinic providing health care." Id. $\$ 55-7 \mathrm{~B}-2$ (a) to -(c) (2000); see id. $\S \S 16-5 B-1$ to -12 (2000) (licensing of hospitals); id. $\$ \S 16-5 \mathrm{C}-1$ to -18 (2000) (licensing of nursing and personal care homes); id. § 16-5I-1 to -6 (2000) (licensing of hospices).

7 See W. VA. CODE $§ 55-7 \mathrm{~B}-1$ et seq. (1986).

$8 \quad I d . \S 55-7 \mathrm{~B}-2$.

$9 \quad$ Id. $\$$ 55-7B-10 (Supp. 2002).

10 State ex rel. Weirton Med. Ctr. v. Mazzone, No. 30360, 2002 W. Va. LEXIS 97 (June 19, 2002).

11 W. VA. CODE $\S 55-7 B-2(d)$.

12 "Under the common law of this State, a physician-patient relationship was required to maintain a medical malpractice action." Osborne v. United States, 567 S.E.2d 677, 686 (W. Va. 2002) (Maynard, J. dissenting) (citing Weaver v. Union Carbide Corp., 378 S.E.2d 105 (W. Va. 1989)); Sisson v. Seneca Mental Health Council, 404 S.E.2d 425 (W. Va. 1991); Gooch v. West Virginia Dep't of Public Safety, 465 S.E.2d 628 (W. Va. 1995); and Rand v. Miller, 408 S.E.2d 655 (W. Va. 1991). 
providers, ${ }^{14}$ and health care facilities. ${ }^{15}$ The definitions of health care provider and facility depend on licensure in West Virginia or any other state. ${ }^{16}$

In Short $v$. Appalachian $\mathrm{OH}-9,{ }^{17}$ the court examined the statutory definition of "health care provider," and concluded that the MPLA applies to the provision of emergency medical services. ${ }^{18}$ Conversely, in Ricottilli v. Summersville Memorial Hospital, ${ }^{19}$ an action arising from the performance of an autopsy, the court held the MPLA did not apply because a dead body was not a "patient," defined in West Virginia Code section 55-7B-2(e) as a "natural person."20

The MPLA also applies to "third party" actions against health care providers. $^{21}$ The Act "permits a third party to bring a cause of action against a health care provider for foreseeable injuries that were proximately caused by the health care provider's negligent treatment of a tortfeasor patient." ${ }^{, 22}$ In Osborne $v$. United States, ${ }^{23}$ the plaintiffs sought damages for the deaths and severe injuries of a family whose members were either killed or fatally injured in a collision with a vehicle driven by a person intoxicated with alcohol and prescription medications. They sued the driver and also made a claim against the driver's family physician for negligently prescribing medications. ${ }^{24}$ In Osborne, the

W. VA. CODE $\S 55-7 B-2(e)$ (patient defined as "a natural person who receives or should have received health care from a licensed health care provider under a contract, expressed or implied").

14 Id. $\S 55-7 \mathrm{~B}-2$ (c) (health care provider includes "a person, partnership, corporation, facility or institution licensed by, or certified in, this state or another state, to provide health care or professional health care services, including but not limited to a physician, osteopathic physician, hospital, dentist, registered or licensed practical nurse, optometrist, podiatrist, chiropractor, physical therapist, or psychologist, or an officer, employee or agent thereof acting in the course and scope of such officer's, employee's or agent's employment").

is Id. \$ 55-7B-2(b) (health care facility "includes any clinic, hospital, nursing home, or extended care facility in and licensed by the state of West Virginia and any state operated institution of clinic providing health care").

16 See id. § 16-5B-1 to -12 (licensing of hospitals); id. § 16-5C-1 (licensing of nursing and personal care homes); id. $\S 16-5 \mathrm{I}-1$ (licensing of hospices).

$17 \quad 507$ S.E.2d 124 (W. Va. 1998).

$18 \quad$ Id. at 125 Syl. Pt 2.

19425 S.E.2d 629 (W. Va. 1993).

$20 \quad$ Id. at 633.

21 Osborne v. United States, 567 S.E.2d 677 (W. Va. 2002).

22 Id. at 685; see also Osborne v. United States, 166 F. Supp. $2 d 479$ (S.D. W. Va. 2001).

$23 \quad 567$ S.E.2d 677 (W. Va. 2002).

24 Osborne is procedurally complex. Since the defendant physician was practicing in a federally funded clinic, the claim was covered under the Federal Tort Claims Act ("FTCA"). 42 U.S.C. $\S 233$ (2000). Since federal courts have exclusive jurisdiction over FTCA claims, the United States intervened as a party defendant and removed the case to federal court, where the physician was dismissed, and the United States substituted as a party defendant. After a trial to the bench in 
conclusion that third parties can bring suit came from an examination of the MPLA's definition of "medical professional liability," 25 which includes "any liability for damages resulting from the death or injury of a person for any tort or breach of contract based on health care services rendered, or which should have been rendered, by a health care provider or health care facility to a $p a$ tient." ${ }^{26}$ Both the United States District Court and the Supreme Court of Appeals of West Virginia concluded that the use of the terms "person" and "patient" demonstrated the MPLA did not limit recovery to "patients," but rather to "persons.,"27

The date of injury or death also determines whether the MPLA or its 2002 amendments from HB 601 apply to the action. The MPLA applies to injuries and deaths which occurred after June $6,1986 .^{28}$ The provisions of HB 601 apply to injuries occurring after the effective date of the MPLA, ${ }^{29}$ and to cases filed after March 1, 2002. ${ }^{30}$

The date of injury is important because actions for pre-1986 injuries can conceivably be filed for minors because of the lengthy statute of limitations. ${ }^{31}$ Moreover, since HB 601 only applies to post-1986 injuries and deaths, there may arise medical malpractice cases to which neither the MPLA nor HB 601 apply, leaving the determination to the common law of West Virginia.

The statute of limitations for actions for adults injured before 1986 has probably expired. In addition to the two-year statute of limitations, the MPLA contains a general statute of repose of ten years, stating "in no event shall any such action be commenced more than ten years after the date of injury." 32 Such statutes of repose have been upheld as constitutional. ${ }^{33}$ As will be discussed in more detail later in this article, the expansion of the application of tolling doctrines by the Supreme Court of Appeals raises many issues as to whether injury and death actions can be brought despite the apparent expiration of the statute of

federal court resulted in a plaintiff's verdict of $\$ 4.2$ million dollars, the case came back to the West Virginia Supreme Court by way of certified question. Osborne, 166 F. Supp. 2d at 479 (certifying question to Supreme Court of Appeals of West Virginia).

25

26

27

28

29

30

31

32

W. VA. CODE § 55-7B-2(d).

Id. (emphasis added).

Osborne, 166 F. Supp. 2d at 496-97; Syl. Pt. 5, Osborne, 567 S.E.2d at 678.

W. VA. CODE $\$ 55-7 B-10$ (Supp. 2002).

Id. $\S 55-7 \mathrm{~B}-10(\mathrm{a})$.

Id. \& 55-7B-10(b).

ld. §55-2-15 (2000).

ld. § 55-7B-4 (2000).

Donley v. Bracken, 452 S.E.2d 699 (W. Va. 1994); Gibson v. West Virginia Dep't of Highways, 406 S.E.2d 440 (W. Va. 1991). 
limitations. However, the ten-year statute of repose should eliminate pre-1986 adult claims as an outside limit on the application of any tolling doctrine. ${ }^{34}$

Actions for injuries to minors and incompetents may still exist because of the long statute of limitations. ${ }^{35}$ Generally, under West Virginia Code section 55-2-15, minors have until the age of majority plus two years to file suit, though no action may be brought more than twenty years after the injury. ${ }^{36}$ The age of majority in West Virginia is eighteen years, so these actions potentially exist until 2006. ${ }^{37}$ The twenty-year statute of repose in West Virginia Code section 55-2-15 is constitutional, ${ }^{38}$ and not subject to extension via the "discovery rule." 39

The MPLA shortened the statute of limitations for injuries to minors. ${ }^{40}$ West Virginia Code section 55-7B-4(b) requires that actions for minors less than ten years old must be brought within two years of injury or prior to the minor's twelfth birthday, whichever is longer, subject to the ten year overall limitation contained in section 55-7B-4(a). Actions for injuries to minors ten years and older are subject to the MPLA's general two year statute of limitations. ${ }^{41}$ Both provisions are subject to the MPLA's ten-year statute of repose. ${ }^{42}$

An identical provision shortening the statute of limitations for minors in the governmental immunity statute was struck down as unconstitutional in Whitlow v. The Board of Education of Kanawha County. " "[West Virginia Code section] 29-12A-6 violates the Equal Protection Clause found in Section X of

\footnotetext{
$34 \quad$ See infra note 49 and accompanying text.

35 W. VA. CODE $§ 55-2-15$.

$36 \quad$ Id.

$37 \quad 1986$ plus eighteen years is 2004. 2004 plus two years is 2006 .

38 Albright v. White, 503 S.E.2d 860 (W. Va. 1998).

39 Donley v. Bracken, 452 S.E.2d 699 (W. Va. 1994).

40 W. VA. CODE $\S 55-7 B-4(b)(2000)$.

$41 \quad$ Id. $\$ 55-7 \mathrm{~B}-4(\mathrm{a})$.

$42 \quad I d$.
}

43438 S.E.2d 15 (W. Va. 1993). In Whitlow, the supreme court considered the constitutionality of W. VA. CODE $\S 29-12 A-6(b)$ which, like the MPLA, provided

[a]n action against a political subdivision to recover damages for injury, death, or loss to a minor, brought by or on behalf of a minor who was under the age of ten years at the time of such injury, shall be commenced within two years after the cause of action arose or after the injury, death or loss was discovered or reasonably should have been discovered, whichever last occurs, or prior to the minor's twelfth birthday, whichever provides the longer period.

W. VA. CODE $\S 29-12 A-6(b)$ (1986). The Whitlow court held the specific statute took precedence over the general tolling provision for minors and incompetents set forth in W. VA. CoDE \$ 55-215. 438 S.E.2d at 15. 
Article III of the West Virginia Constitution to the extent that it denies to minors the benefit of the statute of limitations provided in the general tolling statute., ${ }^{, 44}$ Although Whitlow does not directly address whether the ten-year statute of repose for MPLA claims applies to minors, it leaves open the possibility that "preMPLA" actions may still exist.

Certainly, the vast majority of newly filed cases will be governed by the MPLA and HB 601. The practitioner, therefore, must be familiar with both statutes and the case law interpreting the MPLA. To the extent the common law of medical malpractice applies to those rare cases which fall outside the MPLA and HB 601, the reader is referred "to the stacks" since this article will focus primarily on the law in West Virginia since the enactment of the MPLA in $1986 .^{45}$

\section{STATUTES OF LiMITATION}

The MPLA codified a two-year statute of limitations as well as two tolling doctrines, the discovery rule and fraudulent concealment. ${ }^{46}$ West Virginia Code section 55-7B-4(a) states:

A cause of action for injury to a person alleging medical professional liability against a health care provider arises as of the date of the injury, except as provided in subsection (b) of this section [relating to minors], and must be commenced within two years of the date of such injury, or within two years of the date when such person discovers, or with the exercise of reasonable diligence should have discovered such injury, whichever last occurs: Provided, that in no event shall any such action be commenced more than ten years after the date of injury. ${ }^{47}$

44 Whitlow, 438 S.E.2d at 23 (citing W. VA. CODE $§ 55-2-15$ ).

45 The "pre-MPLA" law of medical malpractice was exhaustively examined in Michael J. Farrell's article in this journal. Michael J. Farrell, The Law of Medical Malpractice in West Virginia, 82 W. VA. L. REV. 251 (1979). This article will not extensively address "pre-MPLA law" except where it still appears to apply. The alert reader should read Farrell's article, both for its historical as well as practical perspective. This journal has regularly published other articles related to medical malpractice. See, e.g., Barbara R. Benninger, Note, Nursing Malpractice - The Nurse's Duty to Follow Orders, 90 W. VA. L. REV. 1291 (1988); James P. McHugh, Comment, Emergency Medical Care for Indigents: All Hospitals Must Provide Stabilizing Treatment Or Pay the Price, 93 W. VA. L. REv. 165 (1990); David Zell Myerberg, Note, The Fourth Circuit's Baby K Decision: "Plain Language" Does Not Make Good Law, 98 W. VA. L. REV. 397 (1995).

W. VA. CODE § 55-7B-4(a) (Supp. 1992).

47

Id. 
Section 55-7B-4(c) also tolls the statute of limitation for fraudulent concealment, stating that the "periods of limitation set forth in this section shall be tolled for any period during which the health care provider or its representative has committed fraud or collusion by concealing or misrepresenting material facts about the injury.,"48

\section{A. The Discovery Rule}

The discovery rule has been the subject of a series of decisions interpreting both the MPLA and general civil cases. ${ }^{49}$ The supreme court adopted a general approach to the discovery rule, applicable to all torts, in Cart $v$. Marcum: ${ }^{50}$

[W]e hold today that the "discovery rule" is generally applicable to all torts, unless there is a clear statutory prohibition of its application. However, by declaring the existence of a "discovery rule" we do not eviscerate the statute of limitations: the statute of limitations will apply unless the handicaps to discovery at the time of the injury are great and are largely the product of the defendant's conduct in concealing either the tort or the wrongdoer's identity.

The "discovery rule," then, is to be applied with great circumspection on a case-by-case basis only where there is a strong showing by the plaintiff that he was prevented from knowing of the claim at the time of the injury. The general rule is that mere ignorance of the existence of a cause of action or of the identity of the wrongdoer does not prevent the running of a statute of limitations. In order to benefit from the rule, a plaintiff must make a strong showing of fraudulent concealment, inability to comprehend the injury, or other extreme hardship .... ${ }^{51}$

Fraudulent concealment includes "concealment of the injury itself or the identity of the tortfeasor." ${ }^{, 52}$ Inability to comprehend the injury includes a surgeon leav-

$48 \quad$ Id. $\$ 55-7 \mathrm{~B}-4(\mathrm{c})$

49 For a good overview of tolling doctrines, see Vincent Paul Cardi, Determining the Appropriate Time Limitations on Attorney Malpractice Lawsuits in West Virginia: A Brief Overview, 95 W. VA. L. REV. 913 (1990).

40 423 S.E.2d 644 (W. Va. 1992).

$51 \quad$ Id. at 648 (footnotes omitted).

52 Id. at 648 n.13; see also Trafalgar House Constr., Inc. v. ZMM, Inc., 567 S.E.2d 294 (W. Va. 2002). 
ing a piece of surgical equipment in a patient or exposure to hazardous chemicals where the effects were only detectable at a later time. ${ }^{53}$

Cases involving the inability to comprehend an injury are governed by Gaither v. City Hospital. ${ }^{54}$ Applying West Virginia Code section 55-7B-4, the Gaither court reversed the dismissal of a civil action filed almost five years after the negligent act. ${ }^{55}$ Discussing the facts, the court noted there were no circumstances giving the plaintiff any reason to investigate whether malpractice was the cause of the loss of his leg. ${ }^{56}$

[T]here was no affirmative duty on the part of the appellant to have sought the hospital records earlier than he did, and no duty on the part of the appellant's parents to have informed their adult son of their discussions with his treating physicians. It is therefore irrelevant whether the appellant could have requested the records before 1993, or spoken with his parents about the cause of the loss of his leg. ${ }^{57}$

The court indicated that whether the claim was barred by the statute of limitations was a question of fact for the jury and remanded the case for proceedings consistent with the opinion. ${ }^{58}$

The Gaither court stated that the discovery rule applies "where the plaintiff knows of the existence of an injury, but does not know the injury is the result of any party's conduct other than his own."59 Therefore, the court held that in all tort actions, under the discovery rule, the statute of limitations runs only when the plaintiff knows or by the exercise of reasonable diligence should know (1) he has been injured, (2) the identity of the entity who owed the plaintiff a duty to act with due care and who may have engaged in conduct that breached that duty, and (3) that the conduct of that entity has a causal relation-

\footnotetext{
$53 \quad$ Cart, 423 S.E. 2 d at 648 n.14.

$54 \quad 487$ S.E.2d 901 (W. Va. 1977).

55 Id. After the plaintiff injured his leg in a motorcycle accident, he was transferred from a West Virginia hospital to a trauma center in Baltimore, Maryland. There, his parents were told that if he had been transported earlier, the blood flow might have been restored and he would not have lost his leg. No one, including his parents, discussed this with the plaintiff. He thought the loss of his leg was due to the motorcycle accident until 1993, when he was told by a prosthetic specialist that it was due to loss of circulation. Then, his parents told him for the first time of their conversations with the physicians and he contacted an attorney, who filed suit within two years. The circuit court's dismissal on statute of limitations grounds was appealed.
}

Id. at 910 .

Id.

Id. at 909-10.

Id. at 908 . 
ship to the injury. ${ }^{60}$ "Knowledge sufficient to trigger the limitation period requires something more than a mere apprehension that something may be wrong . ..."61 On the other hand, "once a patient is aware, or should reasonably have become aware, that medical treatment by a particular party has caused a personal injury, the statute begins." 62

Gaither must be analyzed in light of its facts and the rule in Cart. ${ }^{63}$ The most critical fact of Gaither is the nature of the injury to the plaintiff, who lost his leg due to the interruption of circulation occurring after the injury he sustained in the motorcycle accident. The delay in identifying and treating the vascular injury, not the accident, caused (or contributed to) the need for amputation. $^{64}$ The focus of Gaither, therefore, was on the reasonable knowledge of the plaintiff as to why he lost his leg, and whether he should have known the delay in treatment was the cause, as opposed to the original traumatic injury. ${ }^{65}$ Gaither, then, is most analogous to cases where a foreign object is left in the patient's body during surgery, or to latent injuries not discoverable by the patient. ${ }^{66}$ In those cases, the statute begins to run upon discovery of the object or injury. ${ }^{67}$ Similarly, Gaither emphasizes the unfairness of denying recovery to a plaintiff who did not and could not reasonably know how he was injured.

$60 \quad$ Id. at 909

61 Id.; see also Chancellor v. Shannon, 488 S.E.2d 1 (W. Va. 1997) (issue of fact whether plaintiff's knowledge precluded dismissal on SOL grounds); compare Harrison v. Davis, 478 S.E.2d 104 (W. Va. 1996) (mere ignorance not enough, nor are inconclusive allegations that third parties, not named as defendants, misrepresented facts), with Cart v. Marcum, 423 S.E.2d 644 (W. Va. 1992) (mere ignorance of cause of action, or identity of wrongdoer not enough to toll statute of limitations); Findo v. Hamilton, 428 S.E.2d 779 (W. Va. 1993) (statute began to run when plaintiff told of malpractice by subsequent treater); Hill v. Clark, 241 S.E.2d 572 (W. Va. 1978); Morgan v. Grace Hosp., 144 S.E.2d 156 (W. Va. 1965) (the statute of limitations does not commence until the plaintiff has reason to know he was injured due to the defendant's conduct).

62 Gaither, 487 S.E.2d at 909; cf. McCoy v. Miller, No. 30632, 2003 W. Va. LEXIS 2, *11*12 (W. Va. Feb. 27, 2003) ("The crux of the 'discovery rule' has always been to benefit those individuals who were either unaware of their injuries or prevented from discovering them. When this Court augmented the application of the 'discovery rule' to cases beyond those where the defendant actively sought to prevent the discovery of the malfeasance, we did not eradicate the rule's additional objective of benefitting those individuals who were unaware of their injuries due to no fault of their own. .. . The countervailing consideration of whether the prospective plaintiff 'knew or should have known' through the exercise of reasonable diligence of his injury has always been closely intertwined with the 'discovery rule.'") (citing Cart, 423 S.E.2d at 647-48; Gaither, 487 S.E.2d at 908; and Harrison v. Seltzer, 268 S.E.2d 312, 314 (W. Va. 1980)).

63 See id. at 908 (discussing difference between Cart and Gaither).

64 See id. at 910.

$65 \quad I d$.

66 See Donley v. Bracken, 452 S.E.2d 699 (W. Va. 1994) (patient informed infant died due to lack of oxygen and believed it was due to negligence); see also Harrison v. Davis, 478 S.E.2d 104 (W. Va. 1996) (death of infant placed plaintiff on notice). 
The discovery rule also applies to wrongful death cases, which are subject to a two-year limitation of action. ${ }^{68}$ In Bradshaw $v$. Soulsby, ${ }^{69}$ the plaintiff filed a wrongful death action within two years of the date of the report of autopsy of her deceased husband, but beyond two years from the date of death. ${ }^{70}$ She sought the protection of the discovery rule, arguing she could not know the reason for the death until the autopsy result was available. ${ }^{71}$ The supreme court agreed. $^{72}$ In a decision authored by Justice Starcher, the court held:

In a wrongful death action, under the discovery rule, the statute of limitation contained in [West Virginia Code section] 55-76(d) [(1992)] begins to run when the decedent's representative knows or by the exercise of reasonable diligence should know (1) that the decedent has died; (2) that the death was the result of a wrongful act, neglect, or default; (3) the identity of the person or entity who owed the decedent a duty to act with due care and who may have engaged in conduct that breached that duty; and (4) that the wrongful act, neglect or default of that person or entity has a causal relation to the decedent's death. ${ }^{73}$

Bradshaw overruled Miller $v$. Romero, ${ }^{74}$ where the supreme court refused to apply the "discovery rule" in extending the two-year limitation because wrongful death was a statutory creation. ${ }^{75}$ Under Miller, wrongful death actions had to be filed within two years of the death, unless the plaintiff proved fraudulent concealment by the defendant. ${ }^{76}$ Bradshaw is significant because plaintiffs can now assert they did not know a death was the result of malpractice, thereby obtaining a much longer amount of time to investigate and file claims. Importantly, since Bradshaw interpreted the wrongful death act, the discovery rule now applies to all wrongful death cases, not just those brought against health care providers. $^{77}$

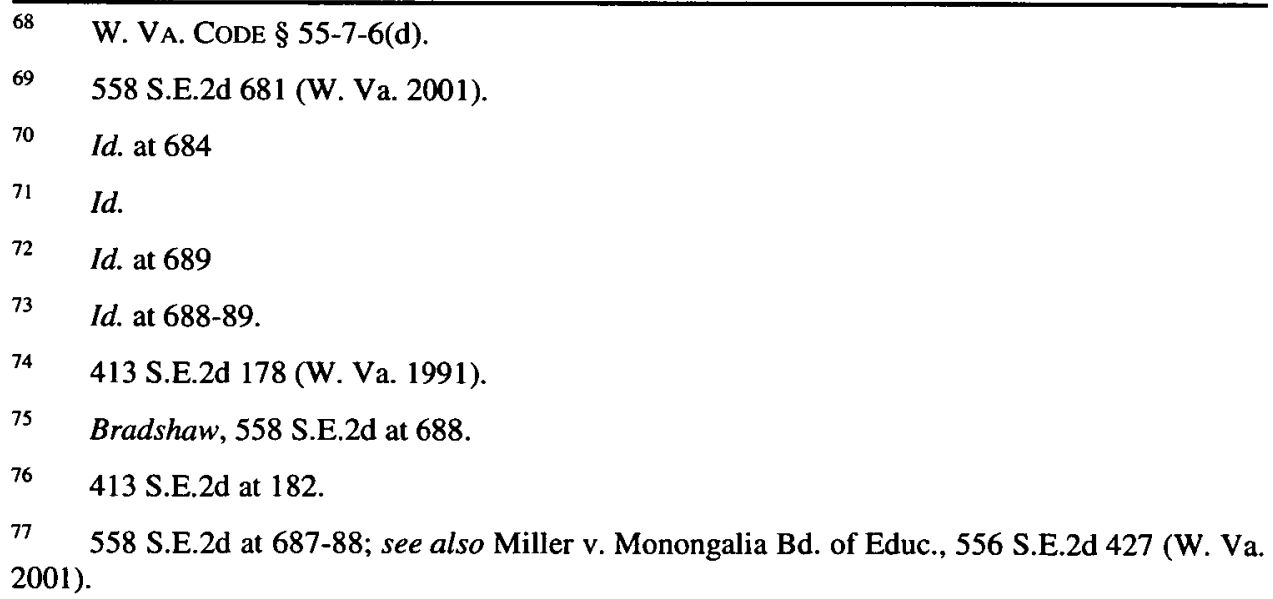


Under the discovery rule, mere ignorance is not enough. The rule does not apply where the injury is immediately known, such as where an infant dies, or where the patient was aware of the injury, even if the patient was not aware of the malpractice. ${ }^{78}$ For example, in Findo $v$. Hamilton, ${ }^{79}$ the plaintiff filed suit five years late. ${ }^{80}$ The circuit court granted summary judgment on statute of limitations grounds. On appeal, the plaintiff argued that a question of fact existed as to the date on which the statute of limitations should have begun, asserting that the statute should not begin to run "until the Plaintiff becomes aware that the action in question constituted malpractice." In this regard, the plaintiff argued that it was "possible to discover an injury without recognizing that malpractice was committed." stated:

[T]he statute did not begin to run when she merely discovered that additional treatment could possibly have been provided or that Dr. Hamilton could have treated her more aggressively. Rather, as in Renner [v. Asli], ${ }^{83}$ the statute began to run when the appellant affirmatively recognized that malpractice had been committed. ${ }^{84}$

The plaintiff also asserted that her inability to recall exactly what the physician told her about the malpractice "raise[d] an issue of material fact precluding summary judgment and requiring the taking of additional evidence." ${ }^{~} 5$ The Findo court rejected this argument, stating:

A review of the appellant's testimony leads to the inescapable conclusion that she was informed by Dr. Tyre in October 1987 that [the defendant's] actions constituted malpractice. While some excerpts from the transcript do indicate the appellant's confusion about particular aspects of her discussions regarding [the defendant's] treatment, she repeatedly answers in the af-

78 See Harrison v. Davis, 478 S.E.2d 104 (W. Va. 1996) (death of infant placed plaintiff on notice); Donley v. Bracken, 452 S.E.2d 699 (W. Va. 1994) (patient informed infant injured due to lack of oxygen and believed it was due to negligence); Findo v. Hamilton, 428 S.E.2d 779 (W. Va. 1993) (knowledge of injury, but not malpractice).

428 S.E.2d 779 (W. Va. 1993).

Id. at $780-81$.

Id. at 781

Id.

280 S.E. $2 d 240$ (W. Va. 1981 )

Findo, 428 S.E.2d at 781 .

Id. at 781 . 
firmative when questioned as to whether she was told in October 1987 that [the defendant's] actions constituted malpractice. $^{86}$

The court found "the appellant's own testimony rendered it impossible to conclude that the appellant had filed her claim within the statute of limitations." 77 Thus, not all statute of limitations cases involve jury issues. ${ }^{88}$ "The principles requiring presentation to the jury need not be stretched to the absurdity." 89

\section{B. Fraud or Collusion by Health Care Provider}

The statute of limitations is also tolled for any period where the health care provider or its representative has committed fraud or collusion by concealing or misrepresenting material facts about the injury. ${ }^{90}$ Inconclusive assertions indicating that third parties, rather than named defendants, misrepresented material facts do not satisfy the requirement that some action by the defendant prevented plaintiff from knowing of the wrong at the time of such injury and, as such, do not toll the statute. ${ }^{91}$ Moreover, evidence of fraudulent concealment by one party will not necessarily be imputed to another party. ${ }^{92}$ This determination is to be made on a case-by-case basis. ${ }^{93}$

\section{Claims by Minors}

As discussed above, the MPLA placed a shorter limitation on the claims of minors. ${ }^{94}$ West Virginia Code section 55-7B-4(b) shortens the statute of limitations for actions for injuries to minors under ten years old, requiring that they be brought within two years of injury or prior to the minor's twelfth birthday, whichever is longer. ${ }^{95}$ The more general statute, West Virginia Code section 55$2-15$, requires actions to be brought by the representative of a minor up to the age of majority and by the minor within two years of reaching "full age" except

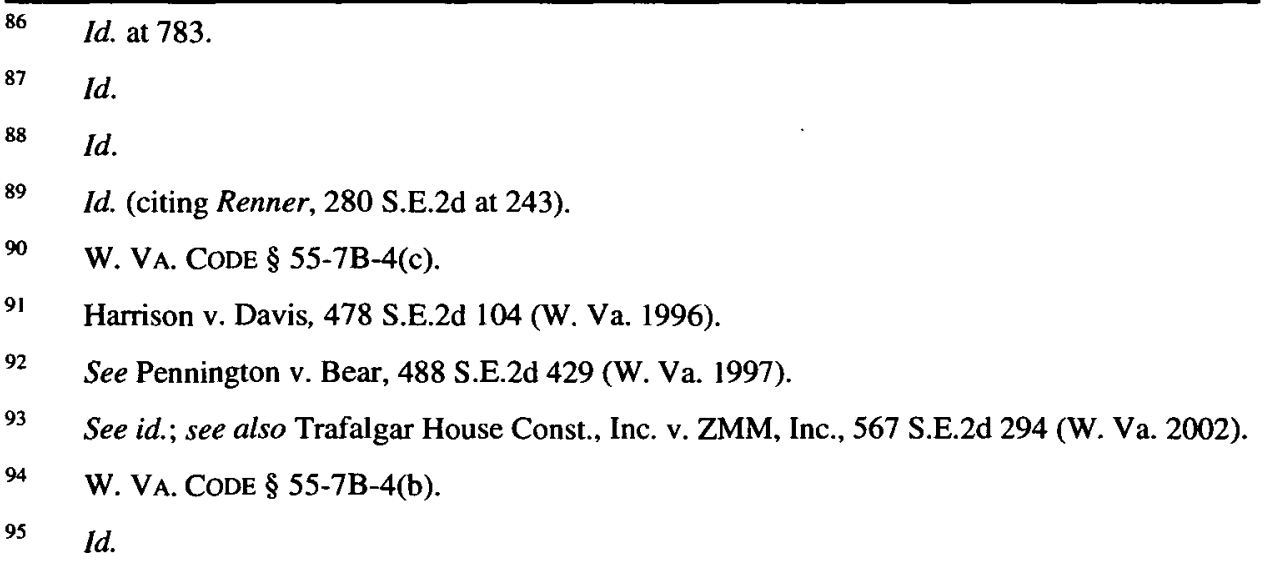


no case could be brought more than twenty years after the injury. ${ }^{96}$ A provision identical to West Virginia Code section 55-7B-4(b) in the governmental tort reform act was struck down as unconstitutional in Whitlow v. Board of Education. ${ }^{97}$ The absolute twenty-year statute of repose on suits by minors and incompetents was upheld in Donley v. Bracken. ${ }^{98}$

Reviewing Cart, Gaither, and Bradshaw demonstrates that the discovery rule truly is applied on a case-by-case basis. Counsel on both sides need to carefully frame the issues and focus their arguments based on the many different cases applying the rule.

\section{Tolling Pre-filing Procedures}

The 2002 amendments to the MPLA provide that a plaintiff may file suit only after satisfying pre-filing obligations, ${ }^{99}$ including sending a notice of claim and certificate of merit to the defendant. ${ }^{100}$ Sending the appropriate prefiling documents in a timely manner satisfies the statute of limitations in the same fashion as filing a complaint under prior law. ${ }^{101}$ To the extent the pre-filing process is completed well within the applicable statute of limitations, the claimant has until the statute expires to file suit. ${ }^{102}$

Where the pre-filing process extends beyond the expiration of the statute of limitations, West Virginia Code section 55-7B-6(h) tolls the statute of limitations while the pre-filing procedures are being followed. ${ }^{103}$ Subsection (h) states:

Except as otherwise provided in this subsection, any statute of limitations applicable to a cause of action against a health care provider upon whom notice was served for alleged medical professional liability shall be tolled from the date of the mailing of a notice of claim to thirty days following receipt of a response to the notice of claim, thirty days from the date a response to the notice of claim would be due, or thirty days from the receipt by

\footnotetext{
$96 \quad$ Id. $\$ 55-2-15$.

97438 S.E.2d 15 (W. Va. 1993).

98452 S.E.2d 699 (W. Va. 1994).

99 W. VA. CODE $§ 55-7 \mathrm{~B}-6$ (a) (2002).

100 Id. $\S 55-7 \mathrm{~B}-6(\mathrm{~b})$. These provisions will be discussed in detail later in this article.

101 Id. § 55-7B-6(h) (tolling of statute of limitations upon mailing of notice of claim and certificate of merit); see Johnson v. Nedeff, 452 S.E.2d 63 (W. Va. 1994) (complaint must be timely received; mailing does not satisfy requirement of filing within the statute of limitations); Winston v. Wood, 437 S.E.2d 767 (W. Va. 1993) (filing determined by date filed with clerk).

W. VA. CODE $§ 55-7 B-6(h)$.

103

Id.
} 
the claimant of written notice from the mediator that the mediation has not resulted in a settlement of the alleged claim and that mediation is concluded, whichever last occurs. If a claimant has sent a notice of claim relating to any injury or death to more than one health care provider, any one of whom has demanded mediation, then the statute of limitations shall be tolled with respect to, and only with respect to, those health care providers to whom the claimant sent a notice of claim to thirty days from the receipt of the claimant of written notice from the mediator that the mediation has not resulted in a settlement of the alleged claim and that mediation is concluded. ${ }^{104}$

Thus, suit is timely as long as it is filed within 30 days of the date the defendant's response is sent or would be due (calculated from the date of the certified mail receipt). ${ }^{105}$ The statute remains "tolled" during mediation, if requested. ${ }^{106}$ Where mediation is requested, the complaint must be filed within thirty days of written notice from the mediator of an unsuccessful mediation. ${ }^{107}$ If only one of multiple defendants requests mediation, the statute is tolled with respect to all defendants to whom the claimant sent a notice of claim. ${ }^{108}$

\section{PRE-FILING Obligations}

Actions filed after March 1, 2002, are subject to the pre-filing procedures established by HB $601 .{ }^{109}$ HB 601 requires a claimant to serve each health care provider with a notice of claim and certificate of merit thirty days before bringing suit. ${ }^{10}$ Both the notice and certificate must be timely sent

104 Id.

105 As an observation, an argument has been made that HB 601 "shortens" the statute of limitations by thirty days because the certificate of merit must be filed thirty days before suit can be filed. To the contrary, as long as the notice of claim and certificate of merit are served within the statute of limitations, the statute is tolled for the pendency of the pre-filing process.

106 W. VA. CODE $\$ 55-7$ B-6(h).

$107 \quad I d$.

108 Id.

$109 \quad I d$.

110 Other states have enacted certificate of merit legislation in medical negligence cases and in other cases, such as professional negligence, products liability and sexual abuse. Jefferey A. Parness \& Amy Leonetti, Expert Opinion Pleading: Any Merit to Special Certificates of Merit?, 1997 BYU. L. REV. 537. Other states with varying degrees of certificate of merit requirements for medical professional liability actions include: New York, N.Y. C.P.L.R. 3012-a (McKinney 1991); Georgia, GA. CODE ANN. § 9-11-9.1 (1987); Florida, FLA. STAT. ANN. § 766.104 (West Supp. 1997); Illinois, 735 ILL. COMP. STAT. ANN. 5/2-622 (West 1997); Missouri, MO. ANN. STAT. § 538.225 (West 1988); Texas, TEX. REV. CIV. STAT. ANN. art. 4590i (Vernon 1997); Michigan, MICH. COMP. LAWS ANN. § 600.2912d (West Supp. 1997); Minnesota, MINN. STAT. 
within the applicable statute of limitations; however, mailing the documents tolls the statute of limitations. ${ }^{111}$ Once served with these documents, the health care provider has the option to request pre-suit mediation. ${ }^{112}$ When mediation is requested, the claimant has the right to depose the health care provider before or during mediation. ${ }^{113}$

These provisions are aimed at deterring the filing of actions without expert testimony and providing a mechanism for voluntary early settlement of claims. ${ }^{114}$ While other states have certificate of merit requirements, it appears West Virginia may be the first to incorporate early mandatory mediation and deposition. ${ }^{115}$

For years, West Virginia law has required the introduction of expert testimony to prove medical malpractice. ${ }^{116}$ However, West Virginia Code section 55-7B-6(a) requires a preliminary showing of expert support before the action is filed. ${ }^{17}$ Section 55-7B-6(a) is mandatory and states "no person may file a medical professional liability action against any health care provider without complying with the provisions of this section." certificate of merit is mandatory, failure to file requires dismissal of actions filed in violation of section $55-7 \mathrm{~B}-6(\mathrm{a}){ }^{119}$

ANN. § 145.682 (West 1989 \& Supp. 1997); and New Jersey, N.J. STAT. ANN. § 2A:53A-27 (West Supp. 1997).

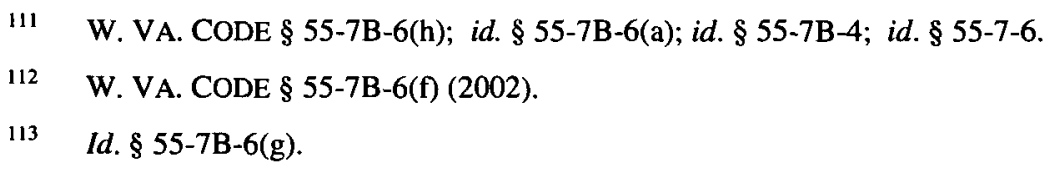

114 Commenting on the Illinois certificate of merit statute, one court stated the "provision is designed to reduce the number of frivolous medical malpractice suits that are filed and to eliminate such actions at an early stage, before the expenses of litigation have mounted." Jackson $v$. Michael Reese Hosp., 689 N.E.2d 205, 210 (Ill. App. Ct. 1998) (holding, however, that certificate of merit statute did not apply to action based on spoliation of evidence).

115 The notice of claim and certificate of merit provisions are not as intrusive as more elaborate malpractice panels seen in other states like Kansas, Virginia and Indiana. Where the provision may have its most important effect is in cases where multiple defendants are named first, then investigated and perhaps dropped later. In a sense, the certificate of merit formalizes an expert screening process already used by experienced plaintiffs counsel. The tradeoff is the additional cost to the plaintiff in securing the report as opposed to merely obtaining an oral or informal evaluation. West Virginia has long had mediation in its trial court rules. See W. VA. Trial Ct. R. 25.

116 See Banfi v. Am. Hosp. for Rehab., 529 S.E.2d 600 (W. Va. 2000); Short v. Appalachian OH-9, 507 S.E.2d 124 (W. Va. 1998); Fortney v. Al-Hajj, 425 S.E.2d 264 (W. Va. 1992); McGraw v. St. Joseph's Hosp., 488 S.E.2d 389 (W. Va. 1985).

117 W. VA. CODE $\$ 55-7 B-6(a)$.

$118 \quad$ Id

119 Other courts have held that failure of plaintiffs to serve notice of claim and a screening of merit prior to the filing of a medical professional liability claim against any health care provider requires dismissal of the action. "[A] plaintiff who files a complaint without the affidavit of merit 
The notice of claim and certificate of merit must be served by certified mail, with return receipt requested. ${ }^{120}$ The notice of claim "shall include a statement of the theory or theories of liability upon which a cause of action may be based, together with a screening certificate of merit."121 The notice of claim and certificate of merit must be timely served within the applicable statute of limitations. ${ }^{122}$

West Virginia Code section 55-7B-6(b) defines the requirements of the certificate of merit:

The certificate of merit shall be executed under oath by a health care provider qualified as an expert under the West Virginia

is subject to dismissal without prejudice." Barlett v. N. Ottawa Cmty. Hosp., 625 N.W.2d 470, 473 (Mich. Ct. App. 2001); see also Frieson v. S. Fulton Med. Ctr., 564 S.E.2d 821 (Ga. Ct. App. 2002) (complaint was dismissed as to one defendant for plaintiff's failure to attach an expert affidavit to her complaint, as required by GA. CODE ANN. § 9-11-9 (2002)); Williams v. United States, No. 4:01 CV 23, 2001 U.S. Dist. LEXIS 10454 (Mich. July 17, 2001) (dismissal without prejudice for failure to file certificate); Teffeteller v. Univ. of Minn., 645 N.W.2d 420 (Minn. 2002) ("Failure to comply with these requirements results, upon motion, in mandatory dismissal with prejudice of each cause of action as to which expert testimony is required . ..."); Mello v. Giliberto, 73 S.W.3d 669 (Mo. Ct. App. 2002) (affirming denial of plaintiff's request to stay the proceedings to allow discovery on the defendant's motion to dismiss for failure to file an expert affidavit under MO. ANN. STAT. $\$ 538.225$ (2000)); In re Collum \& Carney Clinic Ass'n, 62 S.W.3d 924, 928 (Tex. App. 2001) (court "had a ministerial duty to dismiss the case with prejudice" for failure to furnish expert affidavit required by TEX. REV. CrV. STAT. ANN. art. $4590 \mathrm{i}, \S$ 13.01(d) (Vernon 2002)); Forrest v. Danielson, 77 S.W.3d 842 (Tex. App. 2002); Garcia v. Palestine Mem'l Hosp., 2002 WL 192359 (Tex. App. 2002) (unpublished; affirming dismissal for failure to have causation expert). Courts have also denied motions to dismiss for lack of certificate of merit. See Chamberlain v. Giampapa, 210 F.3d 154 (3d Cir. 2000) (affirming dismissal for lack of certificate for claims to which statute applied, but not to others); Familia v. Univ. Hosp., 796 A.2d 302 (N.J. 2002) (granting extension of time to file certificate); Martin v. Montefiore Med. Ctr., 161 A.D.2d 526, (N.Y. App. Div. 1990) (motion to dismiss for lack of certificate of merit denied when defendant refused to provide medical records necessary for case); Barreiro v. Morais, 723 A.2d 1244 (N.J. Super. Ct. App. Div. 1999) (dismissal for failure to comply with certificate vacated due to problems plaintiff had in obtaining legible records from defendants). Some courts have struck down certificate of merit statutes as unconstitutional. Ohio struck down its tort reform statute, including a requirement that pleadings alleging medical negligence include documentation of consultation by an expert, OHIO REV. CODE ANN. § 2307.42 (Anderson Supp. 1996), as violative of the court's rulemaking power. Hiatt v. S. Health Facilities, Inc., 626 N.E.2d 71 (Ohio 1994). A North Carolina appeals court struck down its certificate of merit statute as unconstitutional. Sharpe v. Worland, 557 S.E.2d 110 (N.C. 2001).

120 Sending a notice by certified mail creates a rebuttable presumption of receipt. In a case involving notice by certified mail pursuant to statute related to a trustee's sale of property, the supreme court upheld summary judgment against the owner who denied he received a notice, even though the return receipt contained his signature. Dunn v. Watson, 566 S.E.2d 305 (W. Va. 2002).

W. VA. CODE § 55-7B-6(b) (2002).

122 Id. The North Carolina Supreme Court affirmed the dismissal of a case filed as a sham because it was filed the last day of the statute of limitations almost contemporaneously with a voluntary dismissal to gain another year. Estrada v. Burnham, 341 S.E.2d 538 (N.C. 1986). 
rules of evidence and shall state with particularity: (1) the expert's familiarity with the applicable standard of care in issue; (2) the expert's qualifications; (3) the expert's opinion as to how the applicable standard of care was breached; and (4) the expert's opinion as to how the breach of the applicable standard of care resulted in injury or death. ${ }^{123}$

A certificate of merit is required for each defendant health care provider, and cannot be signed by an expert with a financial interest in the litigation. ${ }^{124}$

West Virginia Code section 55-7B-6(c) also recognizes exceptions to the certificate of merit requirement. Where the claimant asserts the action is one for which expert testimony is not required, ${ }^{125}$ "a statement specifically setting forth the basis of the alleged liability of the health care provider in lieu of a screening certificate of merit" is allowed. ${ }^{126}$ Another exception occurs "[i]f a claimant or his or her counsel has insufficient time to obtain a screening certificate of merit prior to the expiration of the applicable statute of limitations . . . " 127 In that circumstance, the notice of claim shall inform the defendants that a certificate of merit will be supplied within sixty days of the health care provider's receipt of the notice of claim. ${ }^{128}$

None of the pretrial submissions (i.e., the notice of claim and certificate of merit) or results of mediation are later admissible "unless the court, upon hearing, determines that failure to disclose the contents would cause a miscarriage of justice." ${ }^{\prime 29}$ Finally, West Virginia Code section 55-7B-6(b) provides "[n]othing in this subsection may be construed to limit the application of rule fifteen of the rules of civil procedure."

Upon receipt of the notice of claim and certificate of merit, the health care provider must make written demand for mediation within thirty days. Failure to respond results in a waiver of the right to pre-suit mediation under the statute, meaning the claimant can proceed to file suit. ${ }^{131}$ If requested, mediation must be conducted within forty five days pursuant to Trial Court Rule 25, unless

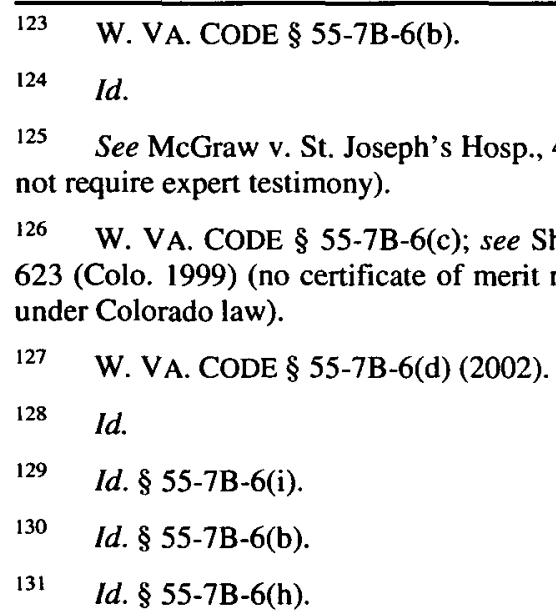
under Colorado law).

W. VA. CODE $\S 55-7 B-6(d)(2002)$.

128

Id.

129 Id. $\$ 55-7 \mathrm{~B}-6(\mathrm{i})$.

130

Id. § 55-7B-6(b).

13

Id. $\S 55-7 \mathrm{~B}-6(\mathrm{~h})$

126 W. VA. CODE § 55-7B-6(c); see Shelton v. Penrose/St. Francis Healthcare Sys., 984 P.2d 623 (Colo. 1999) (no certificate of merit required where case not one requiring expert testimony 
portions of the rule are clearly inapplicable to pre-suit mediation or the supreme court issues pre-filing mediation rules. ${ }^{132}$ Where mediation is requested, the claimant is entitled to take the deposition of the defendant health care provider. ${ }^{133}$

The notice of claim and certificate of merit requirements make the most sense when viewed in the context of the narrow issue they were enacted to resolve. These provisions are focused on MPLA claims filed without expert review, perhaps where the plaintiff hopes discovery will provide a basis for the claim upon later review. ${ }^{134}$ The pre-filing provisions may be most applicable in those cases where the plaintiff "shotguns" defendants, essentially suing all health care providers involved in the patient's care. Pre-filing provisions merely require the plaintiff to procure expert testimony on the standard of care and causation in advance, which is precisely what West Virginia common and statutory law require in order to allow submission of an MPLA case to a jury. ${ }^{135}$

There will undoubtedly be litigation over the notice of claim and certificate of merit provisions. As with most statutes, a constitutional challenge is likely. Courts will undoubtedly be asked to decide whether particular notices of claim and certificates of merit comply with HB 601. As the pre-filing obligation is mandatory, ${ }^{136}$ a notice of claim or certificate of merit that does not comply with the statute may be challenged upon the filing of the complaint. House Bill 601 does not affect either party's right to amend pleadings to add parties; however, the pre-filing process should proceed as to the "new" defendants. ${ }^{137}$ If, after following HB 601, a party seeks to add new defendants, the court should grant leave to follow the provisions of HB 601. For example, a plaintiff or defendant would file a motion for leave to serve notice of claim and certificate of merit, and proceed with filing an amended or third party complaint once the process is complete. Both scenarios could cause delay in the pending litigation, but those not originally sued should not be stripped of the protection of $\mathrm{HB}$ $601 .{ }^{138}$

$132 \quad$ Id. $\S 55-7 \mathrm{~B}-6(\mathrm{~g})$.

133 This is probably the unique part of West Virginia's pretrial notice of claim and certificate of merit statute. The trade off - deposition for mandatory mediation - is likely in place to prevent automatic requests for mediation. A health care provider must make the tactical decision whether early mediation is worth giving a deposition before there is any discovery. Nothing in the statute prevents either side from instituting settlement discussions outside the context of the early mandatory mediation.

134 As an example, a plaintiff may feel forced to sue a particular physician because his or her involvement is not clear from a review of the record. In that circumstance, the physician has an early opportunity to clarify his or her involvement and avoid the filing of a civil action.

135 See infra Part V.F.1. (discussing requirement of expert testimony).

136 W. VA. CODE $\S 55-7 B-6(a)$.

Id.

138 Since HB 601 expressly does not affect amendment of pleadings, an argument can be made 
An interesting situation arises with regard to cross claims and third party claims based solely on the testimony of the plaintiff's expert. In a multidefendant MPLA case, the defendants are entitled by statute to apportionment of fault by the jury. ${ }^{139}$ This is significant in MPLA actions because a defendant with less than $25 \%$ of the fault apportioned by the jury is only severally liable. ${ }^{140}$ Where the plaintiff has served certificates of merit on each defendant, a defendant who files a cross claim for contribution and indemnity should not have to file a new certificate of merit because the cross claim is based on the statutory right to contribution. ${ }^{141}$

Third party actions probably require a different analysis. ${ }^{143}$ A defendant seeking contribution from an absent non-party tortfeasor must bring them into the case by third party complaint, or potentially forgo the claim. ${ }^{144}$ An argument can be made that no "new" certificate of merit is required where the plaintiff's expert is critical of the third party defendant. In that circumstance, the plaintiff's certificate of merit, or the deposition transcript of the plaintiff's expert, served upon the third party defendant with a notice of claim by counsel should satisfy HB 601 . However, where there is no certificate of merit or testimony by the plaintiff's expert against the potential third party defendant, the third party plaintiff probably has to procure a certificate of merit and follow the HB 601 process before filing a third party claim.

While not addressing the pre-filing MPLA requirements, the supreme court has affirmed summary judgment in a case where the third party plaintiff failed to produce evidence supporting his third party claim. In Wilkinson v. Duff, ${ }^{145}$ the defendant physician was sued for negligently prescribing

that once suit is filed, the action is governed only by the Rules of Civil Procedure, meaning the HB 601 pre-filing provisions do not apply to any cross or third party claims. How this provision will be interpreted is unclear based on prior case law. While the supreme court has carved out exclusive constitutional rulemaking powers related to evidence, see Mayhorn v. Logan Med. Found., 454 S.E.2d 87 (W. Va. 1994), it has recognized that the legislature can prescribe procedural matters, as a sort of peaceful constitutional co-existence. See Weirton Med. Ctr. v. Mazzone, 2002 W. Va. LEXIS 97 (W. Va. June 19, 2002) (legislature can mandate status conference). But see Foster v. Sakhai, 559 S.E.2d 53 (W. Va. 2001) (discussing appealability of order granting new trial).

\footnotetext{
139 W. VA. CODE § 55-7B-9(a) (2002).

$140 \quad l d . \S 55-7 \mathrm{~B}-9(\mathrm{~b})$.

141 Whether an MPLA defendant is required to file a cross claim is a good question. There is no language in W. VA. CODE $\$ 55-7 \mathrm{~B}-9$ requiring cross claims to preserve the statutory right to contribution; instead, the language of the statute makes the apportionment of negligence mandatory. Confusion has arisen over the need to file cross claims in light of dicta in some court opinions. See Woodrum v. Johnson, 559 S.E.2d 908 (W. Va. 2001).
}

W. VA. CODE $\$ 55-7 \mathrm{~B}-6(\mathrm{c})$.

W. VA. R. CIV. P. 14.

Howell v. Luckey, 559 S.E.2d 908 (W. Va. 2001).

No. 30399, 2002 W. Va. LEXIS 236 (W. Va. Dec. 5, 2002). 
phentermine to the plaintiff's decedent, in part because she was postpartum and breastfeeding. The physician denied that the patient provided this information, and consistently maintained phentermine was safe and played no role in her death. In his third party complaint, he asserted that the labeling and warning inserts provided by the manufacturer did not address the risk of prescribing the drug to postpartum and breastfeeding women. He argued:

if he had received proper warnings about the hazards of prescribing phentermine to postpartum and breast feeding women, he would have presented those hazards to [the patient] in the oral and written information he provided, and would have altered the questions contained in his medical history so that [the patient] would have given this information to [him]. ${ }^{146}$

The physician therefore sought contribution from the manufacturer asserting the product was defective and unreasonably dangerous for its intended use because of the improper labeling and warning inserts. ${ }^{147}$ As noted by the court, the physician was required to bring the manufacturer into the action for purposes of contribution under Howell v. Luckey. ${ }^{148}$

The court affirmed summary judgment because there was no evidence that the labeling and warning inserts were insufficient or otherwise defective:

In the instant case, [the defendant physician] presented absolutely no evidence of whether it was foreseeable to [the drug manufacturers] that use of phentermine by women such as [the patient] could cause spontaneous coronary artery dissection. [The defendant physician] also did not present any evidence as to the adequacy or inadequacy of the labels and warning inserts provided by the manufacturer and distributor, and did not present any evidence of what a proper label or warning insert should contain. ${ }^{149}$

Instead, the physician relied on the plaintiff's evidence to prove the products liability claim. Plaintiff's evidence was similarly silent as to the warning, focus-

\footnotetext{
$146 \quad I d$. at $* 8$.

$147 \quad$ Id. at $* 7$.

$148 \quad 518$ S.E.2d 873 (1999).

149 Wilkinson, $2002 \mathrm{~W}$. Va. LEXIS 236, at *14-*15.
} 
ing solely on the standard of care. ${ }^{150}$

Moreover, the Wilkinson court found no evidence of causation because the physician admitted that prescribing the drug to a postpartum patient was a breach of the standard of care and asserted that if the patient gave an accurate history, he would not have prescribed the drug. ${ }^{151}$ The court found that the physician's deposition made it clear the labeling and warning inserts did not motivate his dispensing of the drug to the plaintiff's decedent. ${ }^{152}$

Claims for indemnity are different and should not require a certificate of merit. For example, the plaintiff can sue a hospital for the negligence of an emergency room physician not employed by the hospital, holding the hospital liable under principles of ostensible agency, as established in Torrence v. Kusminsky. ${ }^{153}$ Where this occurs, particularly where the emergency room physician is employed by a separate entity (which provides its own insurance), the hospital should have the right to add the "ostensible agent" as a party to respond to the claims of emergency room negligence without a "new" certificate of merit because the legal basis of the claim is implied indemnity arising from the plaintiff's claims. ${ }^{154}$ If there is contractual indemnity between the parties, the basis of the claim is express indemnity, not requiring a certificate of merit. ${ }^{155}$ In either circumstance, HB 601 provides flexibility to allow notice that the claim does not require expert testimony.

\section{LITIGATION OF MPLA CASES}

\section{A. The Complaint}

Once the HB 601 pre-filing procedure is completed - whether by mediation or waiver of mediation - the plaintiff may proceed to file suit. ${ }^{156}$ Complaints, under West Virginia Rules of Civil Procedure, must contain a short, plain statement of the claim. ${ }^{157}$ In MPLA actions, the complaint may not state a dollar amount in the ad damnum clause. West Virginia Code section 55-7B-5 states that "no specific dollar amount or figure may be included in the complaint, but the complaint may include a statement reciting that the minimum

\footnotetext{
$150 \quad$ Id. at $* 15$.

$151 \quad I d$.

$152 \quad I d$.

153408 S.E.2d 684 (W. Va. 1991).

154 See Woodrum, 559 S.E.2d at 908.

155 W. VA. CODE $\S 55-7 B-6(c)$.

156 At this point, this article could veer into discussions of jurisdiction and venue; however, those discussions are left to other articles.

W. VA. R. CIV. P. 8.
} 
jurisdictional amount established for filing the action is satisfied." The defendants have the right to request a statement of damages.

Any party defendant may at any time request a written statement setting forth the nature and amount of damages being sought. The request shall be served upon the plaintiff who shall serve a responsive statement as to the damages sought within thirty days thereafter. If no response is served within the thirty days, the party defendant requesting the statement may petition the court in which the action is pending to order the plaintiff to serve a responsive statement. ${ }^{158}$

\section{B. Access to Medical Records}

West Virginia Code section 55-7B-6a provides for mandatory access to medical records for both parties. Section 55-7B-6a(a) requires the parties to exchange medical records within thirty days of the filing of the last answer. The exchange of records is apparently intended to streamline the process in light of difficulties encountered by both sides in obtaining records. ${ }^{159}$ Both parties are required to provide, as if requested under Rule 34 of the Rules of Civil Procedure, "all medical records pertaining to the alleged act or acts of medical professional liability which: (1) are reasonably related to the plaintiffs' claim; and (2) are in the parties' control." 160

This provision inures to the benefit of all parties, as it ensures that the parties, within thirty days of the filing of the answer, are provided with all available medical records. The statute further states,

the plaintiff shall also provide releases for such other medical records known to the plaintiff, but not under his or her control, but which relate to the plaintiff's claim. If the action is one alleging wrongful death, the records shall be for the deceased except inasmuch as the plaintiff alleges injury to himself or herself. ${ }^{161}$

House Bill 601 provides a mechanism to protect records a party believes are not reasonably related to the claim. ${ }^{162}$ Under section 55-7B-6a(c), the party

\footnotetext{
158 W. VA. CODE § 55-7B-5.

159 Under W. VA. CODE § 16-29-1, the plaintiff is entitled to obtain copies of medical records on written request with a release. HB 601 provides, for the plaintiff, a backup to this provision. W. VA. CODE § 55-7B-6a(a); see also Keplinger v. VEPCO, 537 S.E.2d 632 (W. Va. 2000).

160 W. VA. CODE $\S 55-7 \mathrm{~B}-6 \mathrm{a}(\mathrm{a})$.

$161 \quad$ Id.

$162 I d . \S 55-7 \mathrm{~B}-6 \mathrm{a}(\mathrm{c})(2002)$.
} 
receiving a request for records believed not to be reasonably related "shall provide written notice to the requesting party of the existence of such records and schedule a hearing before the court to determine whether access should be provided." 163

Subsection (d) provides a mechanism for obtaining records that have not been produced:

If a party has reasonable cause to believe that medical records reasonably related to the claim of medical negligence exists and access have not been provided or a release has not been provided therefor, he or she shall give written notice thereof to the party upon whom the request is made, and if said records are not received within fourteen days of the written notice, attain a hearing on the matter before the court. ${ }^{164}$

Moreover, subsection (e) provides that in the event of a hearing, the court at the conclusion of the hearing "shall make a finding as to the reasonableness of the party's request for or refusal to provide records and may assess costs pursuant to the Rules of Civil Procedure." 165

Viewed as a whole, these provisions seem to mirror the usual exchange of records which occurs when lawyers choose to cooperate. These provisions tend to eliminate the expense incurred when there is no cooperation and both parties must issue subpoenas and take "record-keeper" depositions. However, the provisions expressly afford protection where one side asserts that records should or should not be obtained.

In Keplinger $v$. VEPCO ${ }^{167}$ the Supreme Court of Appeals of West Virginia discussed, at length, application of West Virginia Code sections 57-5-4a to $-4 \mathrm{j}$ when obtaining hospital records by subpoena. In 1981 the West Virginia Legislature enacted those statutory provisions, which relate to hospital records. These sections have not been substantively amended since their original enactment. ${ }^{168}$ This statute places specific duties on attorneys and records custodians related to obtaining certain hospital records. Acquiring authorization from the patient allows counsel to avoid the requirements of the statute; however, in the absence of an authorization, counsel would be well advised to review the specifics of the statute. The Keplinger court noted that failure to follow the require-

\footnotetext{
$163 \quad$ Id.

$164 \quad I d . \S 55-7 \mathrm{~B}-6 \mathrm{a}(\mathrm{d})$.

$165 I d . \S 55-7 \mathrm{~B}-6 \mathrm{a}(\mathrm{e})$

$166 \quad I d$

$167 \quad 537$ S.E. 2 d 632 (W. Va. 2000).

168 W. VA. CODE $§ 57-5-4 d$ was amended in 1991 to change the phrase "workmen's compensation" to "workers' compensation." 1991 W. Va. Acts Ch. 16.
} 
ments of West Virginia Code section 57-5-4 when obtaining hospital records by subpoena may open counsel to a possible claim for tortious interference with the physician/patient relationship. ${ }^{169}$

In Keplinger, the supreme court specifically addressed whether a lawyer's failure to comply with West Virginia Code sections 57-5-4a to $-4 \mathrm{j}$ may be grounds for a cause of action for tortious interference with a physician/patient relationship. ${ }^{170}$ The court answered this question in reference to Morris v. Consolidation Coal Co. ${ }^{171}$ In Morris, the court recognized that a patient has a cause of action against a third party who induces a physician to breach his fiduciary relationship, under certain circumstances. ${ }^{172}$ The Keplinger court then distinguished the holding in Morris from Keplinger:

[T]he Morris Court expressly limited its holding to "unauthorized, ex parte oral communications between an employer and the treating physician of a workers' compensation claimant regarding confidential physician/patient information." Thus, by its own terms, Morris would apply to a lawyer's failure to comply with [West Virginia Code sections] 57-5-4a - 4j only if that failure occurred in connection with a workers' compensation case, and only where it involved an unauthorized ex parte oral communication. ${ }^{173}$

However, the court went on to suggest the possible future application of Morris:

While, at some point, we may deem it appropriate to further extend our holding in Morris, we decline to do so in connection

$169 \quad 537$ S.E.2d at 641.

$170 \quad$ Id.

171446 S.E.2d 648 (W. Va. 1994).

172 In Morris the court stated:

A patient does have a cause of action against a third party who induces a physician to breach his fiduciary relationship if the following elements are met: (1) the third party knew or reasonably should have known of the existence of the physician-patient relationship; (2) the third party intended to induce the physician to wrongfully disclose information about the patient or the third party should have reasonably anticipated that his actions would induce the physician to wrongfully disclose such information; (3) the third party did not reasonably believe that the physician could disclose that information to the third party without violating the duty of confidentiality that the physician owed the patient; and (4) the physician wrongfully divulges confidential information to the third party.

446 S.E. $2 d$ at 649 .

173 Keplinger, 537 S.E.2d at 641 (citation omitted). 
with the case at bar. Prior to our decision in the instant case, the law was not clear with regard to the application of [West Virginia Code sections] 57-5-4a to $-4 \mathrm{j}$ to obtaining hospital records for inspection and copying only. Therefore, it could not have been reasonably foreseeable to VEP and its attorneys that their conduct in subpoenaing hospital records for inspection and copying without following the provisions of [West Virginia Code sections] $57-5-4 a$ to $-4 \mathrm{j}$ would give rise to a cause of action. Under these circumstances, VEP should not be subjected to a new cause of action. ${ }^{174}$

Thus, the supreme court made it clear that attorneys issuing subpoenas for hospital records must follow the provisions of West Virginia Code sections 57-5-4a to $-4 \mathrm{j}$ or risk a possible cause of action for tortious interference.

\section{Mandatory Status Conference}

Amended West Virginia Code section 55-7B-6 contains other changes designed to expedite the resolution of medical professional liability cases. West Virginia Code section 55-7B-6b(a) requires the court to convene a mandatory status conference within sixty days after the appearance of the defendant. ${ }^{175}$ For pre-HB 601 actions, section 55-7B-6b(a) requires the conference be held no sooner than nine nor later than twelve months after the last filed answer. ${ }^{176}$ The defendant has the duty to schedule the conference upon proper notice to the plaintiff. ${ }^{177}$

West Virginia Code section 55-7B-6b(b) sets forth the subjects to be discussed at the status conference, requiring the parties to "inform the court as to the status of the action, the identification of contested facts and issues, the progress of discovery and the time necessary to complete discovery." to the statute, the plaintiff must advise the court whether the plaintiff intends to proceed without an expert, whether the expert who signed the screening certificate will testify at trial or whether additional experts will be offered. ${ }^{179}$ Under

Id.

175 W. VA. CODE $\S 55-7 B-6 b(a)$ (2002). The mandatory status conference was included in the original MPLA. W. VA. CODE $\S 55-7 B-6(a)$ (1996) (amended 2001). House Bill 601 sets forth the amended mandatory status conference proceeding in W. VA. CODE $\S 55-7 B-6 b(2002)$. See Daniel v. Charleston Area Med. Ctr., Inc., 544 S.E.2d 905 (W. Va. 2001) (holding that the conference is mandatory, and that plaintiff is entitled to reasonable time if the court decides expert is required).

$\begin{array}{ll}176 & \text { W. VA. CODE } \S 55-7 \mathrm{~B}-6(\mathrm{a})(2000) \text { (amended 2001). } \\ 177 & \text { Id. } \S 55-7 \mathrm{~B}-6 \mathrm{~b}(\mathrm{a})(2002) . \\ 178 & \text { Id. } \S 55-7 \mathrm{~B}-6 \mathrm{~b}(\mathrm{~b}) . \\ 179 & \text { Id. }\end{array}$


the MPLA, if the court determined expert testimony was required, it had to provide a reasonable period of time for the plaintiff to obtain an expert witness. ${ }^{180}$ House Bill 601 states that the court "shall determine whether the plaintiff may proceed without an expert or otherwise establish dates for the disclosure of expert witnesses by both the plaintiff and all defendants."181 The new language drops the "reasonable period of time" requirement if the court determines plaintiff needs an expert, substituting instead the establishment of deadlines. This reflects the normal practice in the circuit courts.

The section 55-7B-6 conference is an important milestone in an MPLA action, particularly as it relates to the necessity of expert testimony. In Daniel $v$. Charleston Area Medical Center, Inc. ${ }^{182}$ and State ex rel. Weirton Medical Center $v$. Mazzone ${ }^{183}$ the supreme court held that the statutory status conference complements the normal status conference provided for in Rule 16 of the West Virginia Rules of Civil Procedure. ${ }^{184}$

The plaintiff in Daniel was being moved to his room in a wheelchair which broke, injuring him. ${ }^{185}$ After suit was filed, the parties entered into a scheduling order which contained deadlines for the identification of experts by both sides. ${ }^{186}$ Because plaintiffs admittedly did not identify a causation expert within the time frame order deadline, the court granted summary judgment. ${ }^{187}$

The supreme court reversed summary judgment as "premature" because the circuit court did not hold the mandatory status conference, or allow the plaintiff a reasonable time to secure an expert witness on causation after determining expert testimony was mandatory, as required by West Virginia Code section 55-7B-6(a)(2):

Through its grant of summary judgment simultaneous with its decision concerning the need for an expert on the issue of proximate cause, the trial court failed to comply with the mandatory language of West Virginia Code $\S 55-7 B-6(a)(2)$, which requires the provision of a "reasonable period of time" for expert retention. Logic suggests that this mandate of requiring a "reasonable period of time" must follow any determination by a trial court regarding the need for an expert, and not precede

\footnotetext{
180 W. VA. CODE § 55-7B-6(a)(2) (2000) (amended 2001).

181 W. VA. CODE $\S 55-7 \mathrm{~B}-6 \mathrm{~b}(\mathrm{~b})$.

182544 S.E.2d 905 (W. Va. 2001).

183 No. 30360, 2002 W. Va. LEXIS 97 (June 19, 2002).

184 Rule 16 of the West Virginia Rules of Civil Procedure generally governs scheduling in civil actions. State ex rel. Crafton v. Burnside, 528 S.E.2d 768, 772 (W. Va. 2000).

$185 \quad 544$ S.E.2d at 906.

$186 \quad I d$.

Id.
} 
such determination. Because the lower court failed to accord Appellant any time whatsoever following its decision regarding the need for an expert witness on proximate cause, we conclude that the lower court erred in granting summary judgment to CAMC. ${ }^{188}$

The unsuspecting plaintiff who is told he needs an expert gets a reasonable time to obtain one. The Daniel court knew this, stating:

Not until this ruling of the trial court was it clear that the action would be resolved pursuant to the provisions of the Medical Liability Act or that an expert witness was required. While West Virginia Code $\S 55-7 \mathrm{~B}-6(\mathrm{a})(2)$ does not expressly address the use of expert witnesses for proximate cause purposes, the discretion vested in the trial judge by this provision to make determinations regarding the need for expert witness testimony coupled with our prior decision in Short [v. Appalachian $\mathrm{OH}$ $\left.9^{189}\right]$ compels the conclusion that upon a trial court's determination that an expert witness is required to prove standard of care or proximate cause in an action brought under the Medical Liability Act, a reasonable period of time must be provided for retention of an expert witness. ${ }^{190}$

Thus, the supreme court added Short's requirement that experts are necessary for causation to section 55-7B-3, which mentions only plaintiff's standard of care expert. $^{191}$

\footnotetext{
$188 \quad$ Id. at 908 .

189507 S.E.2d 124 (W. Va. 1998).

190

Id. (citing Syl. Pt. 5, Short, 507 S.E.2d at 247).

191 The irony of Daniel is Justice Davis' observance that, had it not been an MPLA case, the supreme court would have affirmed summary judgment for the plaintiff's violation of the scheduling order. Id. at 909.
}

As demonstrated by the foregoing case law, precedent would appear to require affirming the trial court in this case. Indeed, had this not been a medical malpractice case within the confines of [West Virginia Code] $\S 55-7 \mathrm{~B}-6$, under the Rules of Civil Procedure we would be compelled to affirm the trial court's decision since the court was correct in requiring plaintiff to use an expert. However, the Rule 16(b) scheduling order in this case was qualified by the application of [West Virginia Code] $\S 55-7 \mathrm{~B}-6$, which, as discussed below, controls the issue of identifying a medical expert in actions for medical professional liability.

1d. The supreme court affirmed dismissal of an MPLA action for plaintiff's repeated failure to comply with court deadlines in McCoy v. Charleston Area Med. Ctr., Inc., 557 S.E.2d 378 (W. Va. 2001). 
Justice Davis concurred in Daniel, suggesting the mandatory status conference should occur before the established deadlines for expert witnesses, should involve a meaningful hearing on any expert issues, and should apply only to medical experts. ${ }^{192}$

The mandatory status conference was further addressed in State ex rel. Weirton Medical Center v. Mazzone. ${ }^{193}$ In Mazzone, the parties agreed to a scheduling order setting expert deadlines. After an agreed extension, the parties identified expert witnesses and began squabbling. The circuit court struck a causation opinion offered by one of the defense experts based upon a late disclosure of the opinion. ${ }^{194}$ Limiting each side to one liability expert, the circuit court further ordered that if defendant physician testified he had not breached the standard of care, he could not call a liability expert. ${ }^{195}$

Like Daniel, the supreme court reversed because the mandatory status conference was not held. ${ }^{196}$ "[T]o further clarify" its decision in Daniel, the Mazzone court held:

[T] he provisions of the Medical Professional Liability Act, W. Va. Code $\S \S 55-7 B-1$ to -11 , govern actions falling within its parameters, subject to this Court's power to promulgate rules for all cases and proceedings, including rules of practice and procedure, pursuant to Article VIII, Section 3 of the West Virginia Constitution. We further hold that the necessity of expert witnesses in medical malpractice cases must be resolved during the mandatory status conference required by $\mathrm{W}$. Va. Code $\S 55-$ 7B-6. Accordingly, dates set forth in an initial scheduling order entered by the court pursuant to W.Va.R.Civ.P. 16 for the identification of expert witnesses are not controlling. ${ }^{197}$

Moreover, the Mazzone court expanded the scope of the mandatory status conference to include defense experts, stating that "neither the plaintiff nor the defendant in an action filed pursuant to the Medical Professional Liability Act shall be required to disclose expert witnesses before the status conference required by West Virginia Code section 55-7B-6 has been held."198

\footnotetext{
192 Justice Davis' thoughtful concurrence in Daniel, describing in some detail the mandatory status conference, is a must read for MPLA litigators. 544 S.E.2d at 909.

193 No. 30360, 2002 W. Va. LEXIS 97 (June 19, 2002).

194 Id. at $* 8$

195 Id. at *7.

196 Id. at $* 24$

$197 \quad$ Id. at $* 18$ (citation omitted)

198 Id. at $* 20-* 21$.
} 
After Daniel, most circuit courts across the state reacted by requiring the scheduling of mandatory status conferences absent a stipulation by the parties that expert testimony on the standard of care is required in particular cases. Mazzone suggests the conference cannot be waived. ${ }^{199}$ Even though the burden is on the defense to initiate the conference, Mazzone reaffirms that it is mandatory, and that section 55-7B-6 requires a meaningful status conference at which expert testimony on both sides of the liability and causation issues shall be discussed. ${ }^{200}$ With the HB 601 amendments moving the conference to sixty days, instead of nine to twelve months, this dialogue will take place earlier in the action, which will help parties avoid the kind of close to trial squabbling seen in both Daniel and Mazzone. ${ }^{201}$

\section{Mandatory Mediation}

In addition to the optional pre-suit mediation, circuit courts are directed by HB 601 to order mandatory mediation in all MPLA actions. ${ }^{202}$ Mandatory mediation is consistent with one goal of HB 601, which is to identify and resolve actions early to reduce cost. ${ }^{203}$ Most circuit courts around the state already require the parties to mediate, regardless of the type of civil action, so this provision may not signal much of a change in everyday practice. For physicians with insurance policies that require consent to settlement, the mandatory mediation provision forces the issue, requiring participation in mediation even though the physician does not consent to settlement. ${ }^{204}$ Timing of mediation in MPLA cases is also a critical issue because of the importance of expert testimony on standard of care and causation to the ultimate evaluation of the case for settlement by both sides.

199 Id. at $* 15-* 16$.

200 Id.

201 Generally, a trial court has the discretion to control its docket. See McCoy v. Charleston Area Med. Ctr., Inc. 557 S.E.2d 378 (W. Va. 2001) (affirming dismissal for violation of scheduling order deadline for experts); Kiser v Caudill, 557 S.E.2d 245 (W. Va. 2001) (finding initial ruling excluding late-disclosed expert appropriate, but also finding abuse of discretion in not allowing expert, since trial was then continued for almost two years). For cases on bifurcation, compare Rohrbaugh v. Wal-Mart Stores, Inc., No. 30441, 2002 W. Va. LEXIS 166 (Oct. 11, 2002), in which the trial court did not err in bifurcating punitive damages issues, with State ex rel. Crafton v. Burnside, 528 S.E.2d 768 (W. Va. 2000), in which the circuit court's refusal to allow the plaintiffs to withdraw an agreement to a bifurcated proceeding was reversed.

202 W. VA. CODE $\$ 55-7 B-6 b(b)(2002)$.

203 See Rita Lowery Gitchell \& Andrew Plattner, Mediation: A Viable Alternative to Litigation for Medical Malpractice Cases, 2 DEPAUL J. HEALTH CARE L. 421 (1999).

204 In this regard, parties can be forced to mediate, but not ordered to settle or make offers. W. VA. TRIAL CT. R. 25.11. An important case about enforcing agreements reached at mediation is Riner v. Newbraugh, 563 S.E.2d 802 (W. Va. 2002). 


\section{E. Sanctions}

West Virginia Code section 55-7B-6a further empowers the circuit courts to sanction frivolous claims or defenses. If the court finds that either party is pursuing frivolous or dilatory claims or defenses "for which there is no reasonable basis in fact or law," it may direct in final judgment that prevailing party recover reasonable litigation expenses, not including attorney's fees. ${ }^{205}$ This provision mirrors Rule 11 of the West Virginia Rules of Civil Procedure, except that it excludes attorney's fees as a sanction. ${ }^{206}$ Under Daniel, procedural legislation co-exists with the Rules of Civil Procedure, but the interrelationship between West Virginia Code section 55-7B-6 and Rule 11 is at best unclear. ${ }^{207}$

\section{F. Experts}

Two issues are important in relation to expert testimony in MPLA actions. The first is the necessity of expert testimony, which will be resolved at the mandatory status conference, discussed above. The second issue is the qualification of an expert to offer testimony in a particular case. In determining the necessity of experts, and the qualifications necessary to testify, several supreme court decisions are important and instructive. ${ }^{208}$

\section{Necessity of Expert Testimony}

The necessity of expert testimony is a threshold issue in MPLA cases. Under the MPLA, experts are generally required to prove the breach of the standard of care and causation. Section 55-7B-7 provides that " $t \mathrm{t}] \mathrm{he}$ applicable standard of care and a defendant's failure to meet said standard, if at issue, shall be established in medical professional liability cases by the plaintiff by testimony of one or more knowledgeable, competent expert witnesses if required by the court."209 Thus, circuit courts have the discretion to determine whether ex-

\footnotetext{
205 W. VA. CODE § 55-7B-6a(f) (2002).

206 Id.
}

207 See generally Thomas J. Hurney, Jr. \& W. Scott Campbell, Rule 11 Sanctions in State and Federal Courts in West Virginia, 90 W. VA. L. Rev. 417 (1988). Whether sanctions are a meaningful threat is a good question. The imposition of sanctions against a party and counsel who sued the expert witnesses who testified in her criminal trial was reversed in Davis v. Wallace, 565 S.E.2d 386 (W. Va. 2002). Conversely, the supreme court affirmed the dismissal of an MPLA action for the plaintiff's continued refusal to adhere to scheduling orders although the basis of the motion was not Rule 11. McCoy v. Charleston Area Med. Ctr., Inc., 557 S.E.2d 378 (W. Va. 2001).

208 See generally State ex rel. Ward v. Hill, 489 S.E.2d 24 (W. Va. 1997), for a discussion of requirements for formal sharing agreements among defendants in order to preserve the right to use experts at trial.

209 W. VA. CODE § 55-7B-7 (emphasis added). 
perts are necessary in a particular case. ${ }^{210}$ Causation must also be proven by expert testimony. ${ }^{211}$ In this regard, the MPLA is consistent with prior law. ${ }^{212}$

Two cases on the necessity of expert testimony stand out as defining the extent of the circuit court's discretion: McGraw v. St. Joseph's Hospital ${ }^{213}$ and Banfi v. American Hospital for Rehabilitation. ${ }^{214}$

The issue in McGraw was whether the plaintiff was required to use expert testimony to prove a claim against the hospital's nurses for allowing a patient to fall out of bed. Reversing summary judgment for the defendant, the supreme court reached the conclusion that the case involved "routine" hospital care within the common knowledge of jurors. ${ }^{215}$ Echoing the pre-MPLA decision in Totten $v$. Adongay, ${ }^{216}$ the court stated:

In medical malpractice cases where lack of care or one of skill is so gross, so as to be apparent, or the alleged breach relates to noncomplex matters of diagnosis and treatment within the understanding of lay jurors by resort to common knowledge and experience, failure to present expert testimony on the accepted standard of care and degree of skill under such circumstances is not fatal to a plaintiff's prima facie showing of negligence. ${ }^{217}$

Moreover, " $[t]$ he standard of nonmedical, administrative, ministerial or routine care in a hospital need not be established by expert testimony because the jury is competent from its own experience to determine and apply a reasonable-care standard.,218

The McGraw court also found the circuit court was clearly wrong in ruling that the plaintiff did not have an expert on the standard of care with respect to the fall. ${ }^{219}$ According to the supreme court, the plaintiff's expert opined that the hospital violated the standard of care by failing to have the side rails up on

\footnotetext{
$210 \quad$ McGraw v. St. Joseph's Hosp., 488 S.E.2d 389 (W. Va. 1997).

211 Daniel v. Charleston Area Med. Ctr., Inc., 544 S.E.2d 905 (W. Va. 2001).

212 See, e.g., Neary v. Charleston Area Med. Ctr., Inc., 460 S.E.2d 374 (W. Va. 1995); Roberts v. Gale, 139 S.E.2d 272 (W. Va. 1964).

488 S.E.2d 389 (W. Va. 1997).

214529 S.E.2d 600 (W. Va. 2000).

$215 \quad M c G r a w, 488$ S.E.2d at 395.

$216 \quad 337$ S.E.2d 2 (W. Va. 1985)

217 McGraw, 488 S.E.2d at 394.

218 Id. at 396 (quoting Cramer v. Theda Clark Mem'l Hosp., 172 N.W.2d 427, 428 (Wis. 1969)). 
the plaintiff's bed, resulting in a fall. ${ }^{220}$ There was also a second incident, where the plaintiff was dropped, as to which the court found the facts "susceptible to a reasonable standard of care that can be determined, without an expert, by the jury." ${ }^{, 21}$ Procedurally, the McGraw court remanded the case for a determination of whether the second incident involved complex management issues, stating that "the trial court may find at a pretrial hearing that expert testimony is necessary on this incident, should the defendant proffer satisfactory evidence that this incident involved complex management issues."222

The McGraw court's analysis of the necessity of expert testimony was followed in Banfi v. American Hospital for Rehabilitation, ${ }^{223}$ a wrongful death action arising from injuries sustained by a patient in a bed fall. Suing the hospital and physician, the plaintiff alleged failure to restrain, failure to prevent the fall, and improper diagnosis and treatment of her injuries. The plaintiff did not identify expert witnesses on either issue, and the circuit court granted summary judgment for the physician. ${ }^{224}$

Addressing whether proving the failure to restrain a patient required expert testimony, the supreme court stated:

[I]t is generally acknowledged that such testimony is necessary when the allegation in question involves a technical medical decision, which is not within the ordinary and common knowledge of the average lay juror. Our research indicates that the majority of jurisdictions considering the question of whether restraining a patient is, in fact, a technical medical decision have concluded that it is a complex determination, and therefore expert testimony is required to educate the jury as to the appropriate standard of care. ${ }^{225}$

$220 \quad$ Id. at 397.

$221 \quad$ Id.

222 Id. at 398. McGraw is based on the assumption, derived from other cases, that some nursing care does not require the exercise of professional judgment. "[R]egistered or licensed practical nurse[s]," however, are expressly included in the MPLA definition of "health care providers." W. VA. CODE $§ 55-7 B-2$ (2002). Moreover, the West Virginia Code recognizes nursing as a profession, requiring licensure and continuing education. See id. § 30-7-1(b) (2002).

223529 S.E.2d 600 (W. Va. 2000).

224 Id. at 604

225 Id. at 606 (citation omitted). For those with bed fall cases, here is a helpful list of the opinions cited by the supreme court as supporting the proposition that the decision to restrain requires expert testimony. See Youngberg v. Romeo, 457 U.S. 307 (1982); Leonard v. Providence Hosp., 590 So. 2d 906 (Ala. 1991); Sexton v. St. Paul Fire \& Marine Ins. Co., 631 S.W.2d 270 (Ark. 1982); Washington Hosp. Ctr. v. Martin, 454 A.2d 306 (D.C. 1982); Butler v. Caldwell Mem'l Hosp., 412 P.2d 593 (Idaho 1966); Taylor v. City of Beardstown, 491 N.E.2d 803 (Ill. App. Ct. 1986); Clites v. Iowa, 322 N.W.2d 917 (Iowa Ct. App. 1982); Bennett v. Winthrop Cmty. Hosp., 489 N.E.2d 1032 (Mass. App. Ct. 1986); Waatti v. Marquette Gen. Hosp., Inc., 329 N.W.2d 526 
Similarly, as to the negligent diagnoses and treatment claim, the Banfi court stated, "whether a defendant has properly diagnosed and/or treated a patient entrusted to his/her care necessitates expert testimony because such a question is outside the common knowledge of the typical jury." ${ }^{226}$ The supreme court concluded, therefore, that the circuit court did not abuse its discretion in requiring expert testimony on the restraint, diagnosis and treatment issues, and affirmed summary judgment for the physician. ${ }^{227}$

The Banfi court reversed the summary judgment for the hospital on the issue "that [it was] negligent in failing to prevent [the plaintiff's] fall." ${ }^{, 228}$ First, the court noted the conflicting facts in the case. The plaintiffs alleged that the patient repeatedly called for help, was ignored by the nurses, and fell as she walked to the bathroom. The defendant, however, contended that the patient was found after the fall, was apologetic, and said she did not call for help so as not to bother anyone. The court found these factual conflicts precluded summary judgment. ${ }^{229}$

The court again stated that expert testimony is not generally required against nurses in bed fall cases. ${ }^{230}$ Relying heavily on McGraw, the court observed:

[C]laims of negligence arising from a hospital patient's fall generally do not require expert testimony as the applicable standard of care is within the common knowledge of the average lay jury. As the case sub judice is remarkably similar to our prior

(Mich. Ct. App. 1982) (per curiam); Reifschneider v. Nebraska Methodist Hosp., 387 N.W.2d 486 (Neb. 1986); Carrigan v. Roman Catholic Bishop, 178 A.2d 502 (N.H. 1962); Mossman v. Albany Med. Ctr. Hosp., 311 N.Y.S.2d 131 (N.Y. App. Div. 1970); Bronaugh v. Harding Hosp., Inc., 231 N.E.2d 487 (Ohio 1967); Murphy v. Schwartz, 739 S.W.2d 777 (Tenn. Ct. App. 1986); Kujawski v. Arbor View Health Care Ctr., 407 N.W.2d 249 (Wis. 1987).

226 Banfi, 529 S.E.2d at 608; see District of Columbia v. Mitchell, 533 A.2d 629 (D.C. 1987); Spring Creek Living Ctr. v. Sarrett, 890 S.W.2d 598 (Ark. 1995); Donovan v. Iowa, 445 N.W.2d 763 (Iowa 1989); Smith v. Weaver, 407 N.W.2d 174 (Neb. 1987); Ramage v. Cent. Ohio Emergency Servs., Inc., 592 N.E.2d 828 (Ohio 1992); Stowe v. McHugh, 699 A.2d 279 (Conn. App. Ct. 1997); Saxton v. Toole, 608 N.E.2d 233 (Ill. App. Ct. 1992); Sorenson v. St. Paul Ramsey Med. Ctr., 444 N.W.2d 848 (Minn. Ct. App. 1989), aff'd as modified, 457 N.W.2d 188 (Minn. 1990); Kelly v. Berlin, 692 A.2d 552 (N.J. Super. Ct. App. Div. 1997); Redding v. Saunders, 625 N.Y.S.2d 115 (N.Y. App. Div. 1995); Murphy v. Schwartz, 739 S.W.2d 777 (Tenn. Ct. App. 1986); Reeves v. Geigy Pharm., Inc., 764 P.2d 636 (Utah Ct. App. 1988); cf. Espinosa v. Little Co. of Mary Hosp., 37 Cal. Rptr. 2d 541, 550 (Cal. Ct. App. 1995).

227 Banfi, 529 S.E.2d at 607.

228 Id. at 608.

229 Id. at 607. The existence of conflicting facts, however, does not excuse the plaintiff from producing expert testimony where required. See Goundry v. Wetzel-Saffle, 568 S.E.2d 5, 8-9 (W. Va. 2002). 


\section{decision of $M c G r a w$, we instruct the circuit court to refer to this precedent during its reconsideration of this issue. ${ }^{231}$}

Interesting in McGraw and Banfi is the supreme court's reliance on decisions from other jurisdictions as to whether restraint, prevention of fall, and diagnosis/treatment were generally held to be technical medical decisions requiring expert testimony, as opposed to an evaluation of the record for expert opinion about the nature of the decision making process. ${ }^{232}$ The court's remand for reconsideration of the issue in both cases strongly suggests that absent evidence from the defendant that the acts in question are complex, requiring expert testimony, it will be an abuse of discretion for circuit courts to require experts in bed fall cases. ${ }^{233}$

Although both Banfi and McGraw focus on bed fall cases, the analysis of the necessity of expert testimony is instructive for any MPLA case. Where the treatment at issue involves complex or medical decisions, expert testimony is required. If it is "routine" then expert testimony is not required.

In Withrow v. West Virginia University Hospitals, ${ }^{234}$ the supreme court affirmed summary judgment for the defendant hospital because of the lack of expert testimony. The issue in Withrow was whether the nurses breached the standard of care by failing to give platelets to a patient pursuant to a physician's order. The court found no evidence the nurses violated the order present in the chart. Further, the plaintiff's expert witness could neither testify that the nurses failed to follow orders nor offer any criticism of the hospital's policies or procedures. $^{235}$ "Consequently, [the plaintiffs] lacked evidence to prove an essential element required to establish a prima facie case of medical negligence against [the hospital]. Therefore, [the hospital] was entitled to summary judgment."236

Several other cases focus on the requirement of expert testimony for complex medical issues. In Goundry $v$. Wetzel-Saffle, ${ }^{237}$ the plaintiff failed to produce expert testimony to support the allegation that the defendant, who was

$231 \quad$ Id. at 608 (citation omitted).

232 Procedurally, Banfi was a "no expert" summary judgment case, so there was no record on the nature of the decision making process in the areas analyzed. In McGraw the court stated that "[a]lthough the defendant has contended on appeal that complex management issues are involved in this case, the defendant has not articulated such issues." McGraw v. St. Joseph's Hosp., 488 S.E.2d 389, 396 (W. Va. 1997). It is clear from Banfi and McGraw that the bare assertion that experts are needed in bed fall cases will not succeed. To the extent the issue is still alive, the defendant seeking to require expert testimony must make a record that the decision in question required the exercise of professional judgment, as opposed to being "routine" care.

See Banfi, 529 S.E.2d at $608 ;$ McGraw, 488 S.E.2d at 397-98.

No. 30463, 2002 W. Va. LEXIS 218 (Dec. 3, 2002).

Id. at $* 11-* 12$.

Id. at $* 12$.

568 S.E.2d 5 (W. Va. 2002). 
treating the plaintiff for menstrual problems, failed to diagnose and treat the plaintiff's pregnancy. The physician asserted that she did not perform a pregnancy test because the plaintiff claimed that she could not be pregnant. However, the plaintiff was pregnant, later delivered a premature infant, and brought suit. $^{238}$ expert testimony. ${ }^{239}$

The supreme court affirmed summary judgment because of the lack of

Under [West Virginia Code section] 55-7B-7 (2000), it is expressly provided that " $\mathrm{t}] \mathrm{he}$ applicable standard of care and a defendant's failure to meet said standard, if at issue, shall be established in medical professional liability cases by the plaintiff by testimony of one or more knowledgeable, competent expert witnesses if required by the court." In other words, in medical malpractice cases "the circuit court has the discretion to determine whether the plaintiff is required to obtain an expert witness[.]"240

The Goundry court also rejected the plaintiff's common knowledge argument. The supreme court recited the analysis of the circuit court's reasoning and stated:

Whether or not a pregnancy test is given to a patient who has denied the possibility of pregnancy is a standard that must be established by an expert and is not within the common knowledge of a lay juror. Also, whether or not a pregnancy test should have been offered is a medical question that relates to standard of care and requires expert opinion. ${ }^{241}$

$238 \quad$ Id. at 7.

239 Id. at $9-10$.

240 Id. at 8 (quoting Short v. Appalachian OH-9, Inc., 507 S.E.2d 124, 131 (W. Va. 1998)). The court further cited Syllabus Point 9 of McGraw v. St. Joseph's Hosp., 488 S.E.2d 389 (W. Va. 1997), for the proposition that " $[t]$ he standard of nonmedical, administrative, ministerial or routine care in a hospital need not be established by expert testimony, because the jury is competent from its own experience to determine and apply a reasonable care standard." Goundry, 568 S.E.2d at 9 n.12.

241 Goundry, 568 S.E.2d at 9 (citing Banfi v. American Hosp. for Rehab., 529 S.E.2d 600 (W. Va. 2000) (affirming summary judgment for defendants, in part, when plaintiff failed to present expert testimony in support of its claims that defendants were negligent by failing to restrain patient and by allegedly misdiagnosing her injuries after her fall); Moats v. Preston County Comm'n, 521 S.E.2d 180 (W. Va. 1999) (requiring plaintiff to utilize a medical expert witness to establish that defendant deviated from the standard of care with regard to its actions during an involuntary commitment proceeding); Hapchuck v. Pierson, 495 S.E.2d 854 (W. Va. 1997) (affirming summary judgment when plaintiff failed to produce medical expert testimony on the issue of a physician's duty to warn); and Neary v. Charleston Area Med. Ctr., Inc., 460 S.E.2d 464 (W. 
The plaintiff argued that the dispute of fact over whether the pregnancy test was offered prohibited summary judgment. The court held that in MPLA actions where experts are required, conflicts in the underlying facts do not preclude the grant of summary judgment for failure to produce a necessary expert. $^{242}$

Pleasants v. Alliance Corp. ${ }^{243}$ addressed, among several issues, the trial judge's decisions to allow the defendants to call an expert disclosed seven months after the agreed deadline and to call two experts as cumulative evidence of the standard of care. The court rejected the argument that the trial judge should not have allowed the late disclosed expert, stating,

While this court does not condone non-compliance by any party with discovery deadlines, we agree with the trial court's decision that scheduling orders were not meant to be used in a punitive fashion to prevent one party from adapting their case strategy to fit a plaintiff's altered theory of the case. ${ }^{244}$

Importantly, the court found the plaintiff was not surprised by the testimony and therefore not prejudiced by the late disclosure. ${ }^{245}$ The court was unable to address the cumulative evidence argument because a trial transcript relevant to the issue was not filed. ${ }^{246}$

Therefore, as to expert testimony, the supreme court's decisions affirm the general requirement that experts are necessary to establish negligence by

Va. 1995) (affirming summary judgment for defendant when plaintiff failed to submit medical expert testimony in support of his failure to warn claim)).

242 Goundry, 568 S.E.2d at 8.

Obviously the two competing theories present disputed material issues of fact. Under our general rule summary judgment would be inappropriate when a case presents material issues of fact that are in dispute. However, medical malpractice cases present an exception to the general rule. Our cases have made clear that "[w]hen the principles of summary judgment are applied in a medical malpractice case, one of the threshold questions is the existence of expert witnesses opining the alleged negligence." Thus, once a trial court makes the discretionary determination that a plaintiff must produce a qualified medical expert in a medical malpractice case, underlying disputed material issues of fact cannot be reached until the plaintiff has produced a qualified medical expert.

Goundry, 568 S.E.2d at 9 n. 10 (citations omitted).

243543 S.E.2d 320 (W. Va. 2000).

Id. at 332 .

Id.

246

Id. 
physicians. This principle, however, does not necessarily extend to decisions of other health care providers, particularly nurses. In more exacting terms, experts are necessary in cases involving the application of medical judgment, but not for acts considered routine, nonmedical, or "ministerial." McGraw and Banfi demonstrate that where the plaintiff relies on the common knowledge doctrine, the defendant needs to make a record demonstrating that the medical issue is one of complex professional judgment requiring expert testimony.

A different issue on the requirement of experts is presented when the plaintiff seeks to proceed under res ipsa loquitur, ${ }^{247}$ asserting that the injury itself proves the negligence. Res ipsa loquitur has narrow application in MPLA cases. In Farley v. Meadows, ${ }^{248}$ the court stated:

"The doctrine of res ipsa loquitur cannot be invoked where the existence of negligence is wholly a matter of conjecture and the circumstances are not proved, but must themselves be presumed, or when it may be inferred that there was no negligence on the part of the defendant. The doctrine applies only in cases where defendant's negligence is the only inference that can reasonably and legitimately be drawn from the circumstances.

Farley involved a failed sterilization. The evidence showed the failure could have been either a surgical error, or simply a complication of the surgery; ${ }^{250}$ thus, the plaintiff did not produce an expert, and the supreme court affirmed summary judgment for the defendant. ${ }^{251}$ Similarly, in Neary v. Charleston Area Medical Center, Inc., ${ }^{252}$ the supreme court rejected plaintiff's attempt

\footnotetext{
247

Syl. Pt. 5, Davidson's Inc. v. Scott, 140 S.E.2d 807 (W. Va. 1965).

404 S.E.2d 537 (W. Va. 1991).

249 Syl. Pt. 2, Farley, 404 S.E.2d at 538 (quoting Syl. Pt. 5, Scott, 140 S.E.2d at 809).

250 See id. at 538-39. The medical issue in Farley was the failure of a sterilization because the silastic band placed on the plaintiff's fallopian tube came off. The evidence showed it could not have been placed in the first place, or improperly placed, or fallen off naturally. See id. at 539 .
}

Id. at 539-40.

Ms. Farley had ample time to retain an expert, and failed to do so. She claims that there is a "conspiracy of silence" among medical professionals, and, of course, there is an understandable reluctance among doctors to testify against fellow doctors with whom they must work every day. However, it is obvious from the abundance of medical malpractice cases that go to trial around the United States, and from the profusion of medical experts advertising their services in the back of legal magazines, that many doctors will gladly don their boxing gloves for a reasonable fee and testify about malpractice matters away from their own home towns.

Id. 
to avoid using an expert by relying upon res ipsa loquitur, stating "the doctrine does not apply under the circumstances of this case because [the patient's surgical] infection could have occurred without anyone's negligence."

Expert testimony in informed consent cases is also an important issue. In Neary, the court stated that experts are not required to establish the scope of the duty to disclose under the "patient need" standard adopted in Syllabus Point 5 of Cross v. Trapp. ${ }^{254}$ However, the inquiry does not end there. Relying on West Virginia Code section 55-7B-7, the supreme court stated:

\begin{abstract}
"Although expert medical testimony is not required under the patient need standard to establish the scope of a physician's duty to disclose medical information to his or her patient, expert medical testimony would ordinarily be required to establish certain matters including (1) the risks involved concerning a particular method of treatment, (2) alternative methods of treatment, (3) the risks relating to such alternative methods of treatment, and (4) the results likely to occur if the patient remains untreated."
\end{abstract}

Thus, while no expert is required to establish that a physician is required to obtain consent as judged by the patient need standard, the plaintiff must have expert testimony to prove the appropriate underlying information. ${ }^{256}$ As a practical matter, this may very well be a distinction without a difference, as informed consent cases cannot proceed without an expert witness.

2. Expert Qualifications

With respect to the qualification of experts, the MPLA specifically requires:

253 Id. at 467; see Walton v. Given, 215 S.E.2d 647, 648 (W. Va. 1975).

254294 S.E.2d 446 (W. Va. 1982); see Neary, 460 S.E.2d. at 468.

$255 \quad$ Neary, 460 S.E.2d. at 468 (quoting Syl. Pt. 5, Cross, 294 S.E.2d at 448); see also Adams v. El-Bash, 338 S.E.2d 381 (W. Va. 1985). While not decided under the MPLA, Belcher v. Charleston Area Med. Ctr., 422 S.E.2d 827 (W. Va. 1992), is an important informed consent case. In Belcher, the court held that a physician could be held liable for failure to obtain informed consent where a minor's parents consented to medical treatment if the minor was "mature." 422 S.E.2d at 835-38. Whether a child is a "mature minor" is a question of fact . . . depending upon the age, ability, experience, education, training, and degree of maturity or judgment . . . [and] the conduct [or] demeanor of the child at the time of the procedure ...." Id. at 838 .

256 See Chamberlain v. Giampapa, 210 F.3d 154, 161-62 (3d Cir. 2000) (noting that under New Jersey's "prudent patient" standard, plaintiff alleging lack of informed consent must produce qualified expert testimony to establish that the risk cited was one that the defendant should have been aware of because it was known to the medical community at the time). 
(a) The opinion is actually held by the expert; (b) the opinion can be testified to with reasonable medical probability; (c) such expert possesses professional knowledge and expertise coupled with knowledge of the applicable standard of care . . ; (d) such expert maintains a current license to practice medicine in one of the states of the United States; and (e) such expert is engaged or qualified in the same or substantially similar medical field as defendant health care provider. ${ }^{257}$

These provisions were likely included in the MPLA to address concerns about "all purpose" experts, i.e., doctors who either testify outside their specialty or simply testify for a living without clinical practice.

These requirements were struck down as unconstitutional. The "same or similar specialty" requirement was initially addressed in Gilman v. Choi, ${ }^{258}$ where the court held it was an abuse of discretion for the circuit court to require plaintiff's expert to have the same board certification as the defendant physician. Then, in Fortney v. Al-Hajj, ${ }^{259}$ the court held that experience in treating the type of injury at issue in a case satisfies the "same or similar field" requirement, finding that a surgeon could testify as to the standard of care of an emergency room physician. Finally, in Mayhorn v. Logan Medical Foundation, ${ }^{260}$ the supreme court struck down the "same or similar" requirement as violative of its constitutional rulemaking power. The court held the Legislature cannot dictate evidentiary requirements because it has "paramount authority" under the constitution to adopt rules of evidence. ${ }^{261}$ Accordingly, the qualifications of experts in MPLA actions are governed by Rule 702 of the West Virginia Rules of Evidence, which provides, "[i]f scientific, technical, or other specialized knowledge will assist the trier of fact to understand the evidence or to determine a fact in issue, a witness qualified as an expert by knowledge, skill, experience, training, or education, may testify thereto in the form of an opinion or otherwise."262

The approach of the supreme court to expert witnesses in MPLA actions has been to lean toward admissibility where there is a minimal showing of qualifications, determined on a case-by-case basis. ${ }^{263}$ Once the expert meets the

\footnotetext{
257 W. VA. CODE $§ 55-7 B-7$ (2002).

258406 S.E.2d 200 (W. Va. 1991).

$259 \quad 425$ S.E.2d 264 (W. Va. 1992).

260454 S.E.2d 87 (W. Va. 1994).

261 See Hicks v. Ghaphery, 571 S.E.2d 317 (W. Va. 2002); Meadows v. Meadows, 468 S.E.2d 309 (W. Va. 1996).
} 
threshold, deficiencies in qualifications are fodder for cross-examination. Illustrative is the court's discussion in Fortney v. Al-Hajj: ${ }^{264}$

While [the defendant] was indeed practicing in the emergency room, it must be acknowledged that the medical subject we are concerned with is not simply the general practice of medicine, but rather the specific issue of treatment of patients with blockages of the nature of that suffered by the Appellee. Consequently, the emphasis must be on whether the proffered expert ... had the requisite experience to testify with regard to that latter issue. While [he] only practiced in an emergency room setting when specifically needed for surgery, he had handled many impacted food cases during his career.

A physician's experience may qualify him to testify regarding areas other than his board certified specialty. The fact that a testifying expert physician may not have precisely the same specialty as a physician defendant does not disqualify that testifying physician as an expert regarding the standard of care to be employed by the physician defendant. By emphasizing the fact that [plaintiff's expert] had not actually practiced emergency medicine, [the defendant] is hedging the issue slightly. The salient inquiry is to what extent [the expert] is qualified under West Virginia Code $\S 55-7 B-7$ to testify as an expert on the issue of [the defendant's] standard of care in treating a patient suffering an impacted food blockage. Based upon the foregoing, we conclude that [the expert] was qualified to provide expert testimony on the issue of the standard of care of a physician rendering assistance to a patient suffering from an impacted food blockage. Any shortcomings which the Appellant believed existed in [plaintiff's expert's] credentials could have properly been the subject of cross-examination. ${ }^{265}$

Vigorous cross-examination will not necessarily "knock out" the plaintiff's expert. In Graham v. Wallace, ${ }^{266}$ the plaintiff alleged the defendant negligently installed an implant in her jaw. After a jury verdict for the plaintiff, the defendant appealed the circuit court's refusal to grant judgment as a matter of law because the plaintiff's expert testimony was insufficient to allow a jury to find a breach of the standard of care. ${ }^{267}$ The supreme court found that the plain-

\begin{tabular}{ll}
\hline 264 & 425 S.E.2d 264 (W. Va. 1992). \\
265 & Id. at $270-71$ (emphasis added). \\
266 & 538 S.E.2d 730 (W. Va. 2000). \\
267 & Id. at 731.
\end{tabular}


tiff's expert direct examination was sufficient to inform the jury as to the expert's opinion of both the required standard of care and his opinion that the defendant breached the standard of care. ${ }^{268}$

The fact the expert was vigorously and successfully cross-examined did not require a directed verdict.

As both a matter of law and as a practical matter, a trial court viewing the evidentiary sufficiency of a party's prima facie case - or an appellate court assessing the sufficiency of evidence where a jury has returned a verdict for a party (as we are doing in the instant case) - simply cannot be required to dissect, analyze, or weigh a party's evidence through the lens of what occurred in cross-examination of a party's witnesses, or of what evidence the opposing party put on in rebuttal - to determine whether a litigant made a sufficient evidentiary case to go to a jury. Such dissection, analysis and weighing would invade the province of the jury. If in the instant case - as the trial court found and we agree - the plaintiff's case in chief through his witnesses' direct testimony and other evidence established a prima facie violation of the standard of care, then the plaintiff met his burden so as to permit submitting that issue to the jury without regard to how the plaintiff's case-in-chief might have been weakened by the defense through cross-examination or rebuttal. ${ }^{269}$

In Foster v. Sakhai, ${ }^{270}$ the defendant asserted plaintiff's expert was not qualified to testify about the way the brain surgery in question was performed because he had not operated in several years and had never performed the particular technique at issue. ${ }^{271}$ Addressing the issue on appeal, the Supreme court stated:

"[A] medical expert, otherwise qualified, is not barred from testifying merely because he or she is not engaged in practice as a specialist in the field about which his or her testimony is offered[.]" Dr. Smith, who was the plaintiff's expert, was also a board certified neurological surgeon. We do not feel it was error

\footnotetext{
$268 \quad$ Id. at 732.

269 Id. (emphasis omitted).

$270 \quad 559$ S.E. 2 d 53 (W. Va. 2001).

271

Id. at 67 .
} 
to allow him to give an opinion concerning the way in which Dr. Sakhai performed the procedure in question. ${ }^{272}$

In Kiser $v$ Caudill, ${ }^{273}$ a neurosurgery case, the court agreed that the plaintiff's expert neurologist was not qualified. In deposition and trial, the neurologist conceded he was not an expert in neurosurgery, did not know the standard of care for the treatment at issue, and did not plan to testify about the standard of care required of a neurosurgeon. At trial, during cross-examination, the expert acknowledged that he was not qualified or trained in the field of neurosurgery and was not familiar with the manner in which neurosurgical procedures are performed. ${ }^{274}$ "Given [the expert's] own admissions about his limited knowledge of neurosurgery," the Kiser court found that the circuit court did not err "by limiting his testimony at trial to the field of neurology." 275

In Taylor v. Cabell Huntington Hospital, ${ }^{276}$ plaintiff challenged the circuit court's decision to allow defendant's nursing witness to testify as an expert. Because expert qualifications are governed by Rule 702 of the West Virginia Rules of Evidence, the supreme court stated:

[W]e believe that the circuit court did not abuse its discretion in admitting the expert testimony of [defendant's nursing expert]. The record reveals that [defendant's nursing expert] has a master's degree in nursing and a $\mathrm{Ph} . \mathrm{D}$. in medical anthropology. She is board certified in emergency nursing and is a full professor and associate dean of the undergraduate nursing program at Marshall University. Therefore, [defendant's nursing expert] qualifies as an expert in standard nursing practices. [Defendant's nursing expert] testified to the standard of care and proper method in which to administer the type of intramuscular injection involved in this case which is certainly specialized knowledge. Finally, this testimony assisted the jury in determining whether Nurse Grim was negligent in the manner in which she injected the appellant. We therefore conclude that the circuit

\footnotetext{
272 Id. at 68 (quoting Gilman v. Choi, 406 S.E.2d 200, 204 (W. Va. 1990)).

273557 S.E. $2 d 245$ (W. Va. 2001).

274 See id. at 249-50.

275 Id. at 250 . The trial court was reversed in part, however, because after the circuit court barred the use of a late disclosed expert, the case was continued for two years. The supreme court found the initial order barring the use of the expert was proper, but on equitable principles should have been changed when the case was continued. Id. at 251. ("There was ample opportunity for additional discovery with respect to [the expert] after the trial was continued.").
} 
court did not abuse its discretion in admitting the testimony of [defendant's nursing expert]. ${ }^{277}$

Interestingly, the Taylor court noted that because the nurse was testifying for the defendants, the MPLA did not apply to her testimony. ${ }^{278}$ West Virginia Code section 55-7B-7 applies "specifically to the manner in which plaintiffs in medical malpractice actions shall establish the applicable standard of care and defendants' failure to meet that standard." ${ }^{279}$ While there is no requirement under the MPLA that the defendant have an expert, all parties' experts must be qualified under Rule $702{ }^{280}$

\section{Standard of Care}

West Virginia Code section 55-7B-3 requires the plaintiff to prove that the health care provider failed to exercise that degree of care expected of a reasonable prudent health care provider in the same profession or class acting in the same or similar circumstances and that such failure was the proximate cause of injury or death. ${ }^{281}$ The factual basis for these fundamental elements will differ in every case. Decisions under the MPLA related to the standard of care focus mainly on jury instructions and challenges to the qualifications of liability experts (discussed above). Important in this discussion are the changes in the law made in decisions involving instructions on medical judgment and multiple methods of treatment.

With regard to the standard of care, in Taylor, a case involving allegations of nursing negligence, the court upheld the following instruction:

$277 \quad$ Id. at 727.

278 Id. (noting that generally nurses are not competent to testify as to the standard of care of physicians); see Stryczek v. Methodist Hosp., Inc., 694 N.E.2d 1186, 1189-90 (Ind. Ct. App. 1998); Taplin v. Lupin, 700 So. 2d 1160, 1163 (La. Ct. App. 1997); Cebula v. Benoit, 652 S.W.2d 304, 309 (Mo. Ct. App. 1983); Sigrist v. Clarke, 935 S.W.2d 350, 356 (Mo. Ct. App. 1996); Morris v. Children's Hosp. Med. Ctr., 597 N.E.2d 1110, 1114-15 (Ohio Ct. App. 1991). Since the MPLA is definition-based, and depends on licensure, reference to the statutory licensing provisions supports this distinction. Compare W. VA. CODE $\S 30-3-4(3)$ (2002) (practice of medicine and surgery defined as "the diagnosis or treatment of, or operation or prescription for, any human disease, pain, injury, deformity or other physical or mental condition"), with W. VA. CODE § 30-71(b) (2002) (restricting nurses to nursing diagnoses and following physician instructions for treatment or to the medical issue of causation) and Short v. Appalachian OH-9, 507 S.E.2d 246 (W. Va. 1998) (nurse not competent to testify about medical causation).

Taylor, 538 S.E.2d at 727.

See Mayhorn v. Logan Med. Found., 454 S.E.2d 87 (W. Va. 1994).

281 Cf. Hundley v. Martinez, 158 S.E.2d 159 (1967) (common law elements of medical malpractice action). Generally, there is no action for negligence without duty owed. Lockhart v. Airco, 567 S.E.2d 619 (W. Va. 2002) (affirming summary judgment based on lack of duty owed). 
For the plaintiff to recover from [the nurse defendant] on her claim, she must prove by a preponderance of the evidence: One, that [defendant] is negligent; and, two, that her negligence was a proximate cause of [plaintiff's] injury. Throughout these instructions, I will be using the term health care provider. That term applies to the defendant, [nurse], who is considered to be a health care provider. When you hear the term health care provider in these instructions, you should think of the defendant and apply that term individually. I want to tell you about the standard of care expected of the health care provider. The standard of care is important because in order for the plaintiff to prove negligence, she must establish, one, the degree of care, skill and learning required or expected of a reasonable, prudent health care provider in the profession or class to which the health care provider belongs acting in same or similar circumstances; and, two, that the health care provider deviated from that standard; and, three, that the deviation was the proximate cause of the injury. ${ }^{282}$

The statutory requirement that the jury be instructed that a breach of the standard of care be proved by expert testimony was addressed in Michael $v$. Sabado, ${ }^{283}$ where the court approved the following instruction:

The Court instructs the jury that in cases involving allegations of medical malpractice, the law recognizes that the complexity of the human body and medical science places questions as to the standard of medical care and causation of the injury claimed beyond the knowledge of the average lay person. Therefore, the law requires that expert medical testimony be presented to establish the standard of care to be exercised by physicians. If you find, from a preponderance of the evidence, that credible evidence does not exist to establish malpractice, then your verdict should be in favor of Dr. Sabado. ${ }^{284}$

Conversely, the jury does not have to be instructed that common knowledge claims do not require expert testimony. In Reynolds v. City Hospital, Inc. ${ }^{285}$ the court rejected plaintiff's argument for an instruction under McGraw

282538 S.E.2d at 728. The West Virginia Supreme Court of Appeals also provides jury instructions for medical malpractice actions at http://www.state.wv.us/wvsca/jury/medprof.htm.

283453 S.E.2d 419 (W. Va. 1994).

$284 \quad$ Id. at 434. 
v. St. Joseph's Hospital ${ }^{286}$ that expert testimony was not necessary to determine whether defendant was negligent in allowing the patient to fall from a hospital bed. Examining the instructions to the jury, the court found no error and agreed $M c G r a w$ was not intended as the basis for giving a jury instruction. ${ }^{287}$

Instructions on the standard of care do not have to specifically detail the plaintiff's theories of liability. In Reynolds, the plaintiff submitted instructions which stated that the jury could find negligence if it found the hospital failed to do six specific activities which were the basis of plaintiff's case. ${ }^{288}$ Instead, the trial court gave a more general instruction requiring the jury to determine whether the defendant deviated from the standard of care, causing injury to the plaintiff and resultant damages. The supreme court found "no error in the trial court's refusal to instruct the jury in language that Ms. Reynolds [plaintiff] erroneously contends stated her theory of the case."289

It is reversible error, however, to instruct the jury that there is a presumption the defendant acted reasonably. In Matheny $v$. Fairmont General Hospital, ${ }^{290}$ the supreme court reversed a defense verdict, in part, because the circuit court instructed the jury it was to presume the defendant performed its duty to the plaintiff. The Matheny court concluded that "[u]nder these circumstances, ... the instructions, when considered as a whole, likely misled 'the jury into believing that a malpractice plaintiff bears a double burden in proving [his or her] case.",291

A significant decision related to standard of care instructions is Pleasants v. Alliance Corp. ${ }^{292}$ Pleasants eliminated the "mistake of judgment" instruction. ${ }^{293}$ This instruction, previously approved in Dye v. Corbin, ${ }^{294}$ states that a mistake in judgment is not negligence unless the physician breaches the standard of care, telling the jury it can and should evaluate the physician's clinical judgment. In Pleasants, the circuit court instructed the jury:

\footnotetext{
$286 \quad 488$ S.E.2d 389 (W. Va. 1995).

287 Reynolds, 529 S.E.2d at 345.

$288 \quad I d$. at 346.

289 Id. at 347; see also Matheny v. Fairmont Gen. Hosp., No. 30256, 2002 W. Va. LEXIS 233 (Dec. 6, 2002) (no error where one instruction suggested defendant had to cause infection, when other instructions and evidence at trial addressed failure to diagnose and treat an existing infection).
}

290 No. 30256, 2002 W. Va. LEXIS 233 (Dec. 6, 2002).

291 Id. at *26 (quoting Gaston v. Hunter, 588 P.2d 326, 349 (Ariz. 1978)) (alteration in original).

292543 S.E.2d 320 (W. Va. 2000).

Id. at 331 . 
A healthcare provider who exercises ordinary skill and care while keeping within recognized and approved methods within the standard of care is not negligent because of a reasonable and honest mistake of judgment. A physician is liable for the result of error or judgment where the error is so gross as to be inconsistent with the degree of skill which it's the duty of the physician to possess. ${ }^{295}$

On appeal, the supreme court observed that many courts are veering away from these instructions based on a potential for jury confusion. Recognizing the statutory elements in the MPLA, the court held that the "mistake of judgment" instruction "wrongly injects subjectivity into an objective standard of care; is argumentative and misleading; and should no longer be used to instruct the jury concerning the relevant standard of care in a medical malpractice action." ${ }^{296}$ However, the court found no reversible error because the remaining jury instructions properly set forth the elements necessary to prove a case under the Medical Professional Liability Act. ${ }^{297}$ To the extent there was any doubt after Pleasants, the supreme court formally reversed Dye v. Corbin in Yates $v$. University of West Virginia Board of Trustees. ${ }^{298}$ Then, in Hicks v. Ghaphery, ${ }^{299}$ the supreme court reversed judgment for the defendant because the circuit court gave a mistake of judgment instruction. The Hicks court made the holdings in Yates and Pleasants retroactive and granted the plaintiff a new trial. ${ }^{300}$

To the contrary, the "multiple methods of treatment" instruction was upheld in Pleasants and Yates. In Pleasants, the instruction was affirmed because there was expert testimony about different tests and drugs ordered for patients presenting symptoms similar to the decedent. ${ }^{301}$ Accordingly,

[f]rom the evidence presented at trial, the jury was clearly informed that the correct diagnosis was not made until after [the decedent's] death. What the "multiple methods of treatment" in-

$295 \quad$ Pleasants, 543 S.E.2d at 329.

$296 \quad$ Id. at 331.

297 In a footnote, Justice Scott indicated he would uphold the giving of a mistake of judgment instruction as long as it omitted subjective terms such as "honest mistake of judgment." Id. at 331 n.30. In a separate opinion, Justice Starcher stated physicians should not get the benefit of "mistake of judgment" instructions, comparing a physician to a driver who runs a stop sign and claims an "honest" mistake. Id. at 332-33. (Starcher, J., concurring in part and dissenting in part).

298549 S.E.2d 681 (W. Va. 2001).

$299 \quad 571$ S.E.2d 317 (W. Va. 2002).

$300 \quad$ Id. at 323.

301 543 S.E.2d at 329. Pleasants bears reading for discussion of several other instruction issues, including proximate cause, elimination of female jurors, and removal of jurors for false responses to voir dire. 
struction did was to advise the jury that there is not just one recognized method of treating a patient who presents with the gastritis symptoms that [the decedent] had. We find no error in the giving of this instruction as the evidence before the jury supported such an instruction. ${ }^{302}$

In Yates, the court was again asked to reject the "multiple methods of treatment" instruction and refused. However, Yates suggests that a defendant seeking the instruction has to put on evidence which "shows that the challenged method of diagnosis or treatment enjoys such substantial support within the medical community that it is, in fact, widely and generally recognized." 303 Moreover,

[i]n order to make this showing, the defendant's expert must opine that the challenged method of diagnosis or treatment has substantial support and is generally recognized within the medical community. This testimony should usually be supported by sufficient extrinsic evidence such as medical textbooks, treatises, journal articles, or other similar evidence. ${ }^{304}$

Finding this evidence was lacking, the Yates court reversed the defense verdict and remanded the case for further proceedings.

Yates is significant for its discussion of the extrinsic evidence required to support the multiple methods of treatment instruction. In this regard, the court strayed from the general application of Rules 702 and 703 of the West Virginia Rules of Evidence regarding experts to impose requirements for defense experts which it has never imposed on plaintiffs. ${ }^{305}$ Rather than simply requiring circuit courts to apply the case-by-case "gatekeeping" analysis of the admissibility of expert testimony dictated by Gentry v. Mangum, ${ }^{306}$ the supreme court suggested a burden apparently applicable only to defense experts. ${ }^{307}$ Yates' burden on defendants to produce extrinsic evidence, like literature, stands in contrast to the supreme court's treatment of plaintiff's experts. In Fortney $v$. Al-Hajj, ${ }^{308}$ the court allowed a surgeon to testify about the standard of care for an emergency room physician because he had more than passing knowledge of the condition at issue, making no provision for the production of any extrinsic

\begin{tabular}{ll}
\hline 302 & Id. \\
303 & Yates, 549 S.E.2d at 690. \\
304 & Id. at 689. \\
305 & Id. \\
306 & 466 S.E.2d 171 (W. Va. 1995). \\
307 & Yates, 549 S.E.2d at 689. \\
308 & 425 S.E.2d 264 (W. Va. 1992).
\end{tabular}


evidence. In Graham v. Wallace, ${ }^{309}$ confusing and contradictory testimony was sufficient to allow plaintiff's case to go to the jury. The Yates court's discussion of the need for extrinsic evidence, however, is dicta, and it remains to be seen whether it is mandatory given the statement that "multiple method" testimony "usually" must be supported by extrinsic evidence. ${ }^{310}$

\section{G. Informed Consent}

The doctrine of informed consent was established in West Virginia in Cross $v$. Trapp, ${ }^{311}$ which stated the general rule:

A physician has a duty to disclose information to his or her patient in order that the patient may give to the physician an informed consent to a particular medical procedure such as surgery. In the case of surgery, the physician ordinarily should disclose to the patient various considerations including (1) the possibility of the surgery, (2) the risks involved concerning the surgery, (3) alternative methods of treatment, (4) the risks relating to such alternative methods of treatment and (5) the results likely to occur if the patient remains untreated.

In evaluating a physician's disclosure of information to his or her patient, relative to whether that patient gave an informed consent to a particular medical procedure such as surgery, this Court hereby adopts the patient need standard, rather than physician disclosure standards based upon national or community medical disclosure practice. Pursuant to the patient need standard, the need of the patient for information material to his or her decision as to method of treatment, such as surgery, is the standard by which the physician's duty to disclose is measured. Under the patient need standard, the disclosure issue is approached from the reasonableness of the physician's disclosure or nondisclosure in terms of what the physician knows or should know to be the patient's informational needs. Therefore, whether a particular medical risk should be disclosed by the physician to the patient under the patient need standard ordinarily depends upon the existence and materiality of such risk with respect to the patient's decision relating to medical treatment. ${ }^{312}$

538 S.E. 2 d 730 (W. Va. 2000).

549 S.E.2d at 689.

Id. at 468; see also Belcher v. Charleston Area Med. Ctr., Inc., 422 S.E.2d 827 (W. Va. 
In Hicks v. Ghaphery, ${ }^{313}$ the supreme court declined to extend the doctrine of informed consent to procedures not recommended by the physician. ${ }^{314}$ The patient argued that the defendant physician should have recommended a certain procedure, and should have obtained informed consent. The physician testified that he did not recommend the procedure because he did not think it was indicated. The court concluded that the issue of whether the physician was negligent or not by failing to recommend the procedure was correctly submitted to the jury. The court held an informed consent instruction was not appropriate, stating that it would be inappropriate to impose a duty on a physician to disclose and recommend a procedure that the physician did not think was appropriate. ${ }^{315}$ Thus, the Hicks court found

that the jury must assess a physician's failure to recommend a procedure in terms of whether he or she violated the applicable standard of care. In other words, "[i]f the procedure is one which should have been proposed, then the failure to recommend it would be negligence under ordinary medical negligence principles and there is no need to consider an additional duty of disclosure." 316

An important area of informed consent in West Virginia involves the "mature minor." In Belcher v. Charleston Area Medical Center, ${ }^{317}$ the court recognized that minors have the right to make informed choices about health care decisions, depending on their maturity. ${ }^{318}$

\section{H. Causation}

Causation presents a complex issue in the MPLA. West Virginia Code section 55-7B-3(b) requires the plaintiff to prove that the failure to meet the standard of care "was a proximate cause of the injury or death." However, the term "proximate cause" is not defined in the MPLA.

1992); Catlett v. MacQueen, 375 S.E.2d 184 (W. Va. 1988); Adams v. El-Bash, 338 S.E.2d 381 (W. Va. 1985).

$313 \quad 571$ S.E.2d 317 (W. Va. 2002).

314 Id. at 325.

315

Id.

316

Id. (quoting Vandi v. Permanente Med. Group, Inc., 9 Cal. Reptr. 2d 463, 467 (Cal. Ct. App. 1992)).

317422 S.E.2d 827 (W. Va. 1992).

318 Id. at 836-37. Belcher contains a detailed discussion of the factors a health care provider must consider in determining maturity and extends a "good faith" defense to the decision making process. Id. at 838. 
Analyzing medical malpractice causation requires consideration of several factors. The primary factor is the causal relationship between the breach of the standard of care and damages, which must be established by expert testimony. ${ }^{319}$ Another threshold issue is reliability of the testimony. ${ }^{320}$ In State ex rel Wiseman $v$. Henning, ${ }^{321}$ the circuit court precluded the plaintiff's medical expert from testifying because it found his testimony unreliable under Wilt $v$. Buracker $^{322}$ and Gentry v. Mangum. ${ }^{323}$ The plaintiff sustained a rib injury in a vehicular accident with the defendants' truck. A biopsy revealed abnormal cells at the site, and the plaintiff later developed cancer of the bone marrow. His expert was prepared to correlate the cancer to the auto wreck, testifying the plaintiff had trauma-induced myeloma.

Performing its gatekeeper functions, the circuit court excluded the expert's testimony, concluding that it showed only a possible or potential causal link. The circuit court also found that the expert could "show no basis in established scientific knowledge because it has not been subjected to testing, peer review or publication, an established error rate, controlling standards, or a general acceptance in the scientific community[.]"324

The Supreme Court of Appeals reversed the circuit court. First, the Wiseman court found the issuance of a writ of prohibition appropriate because the plaintiff did not have a "plain, speedy and adequate remedy" and there was a high likelihood of reversal on appeal. ${ }^{325}$ The court also found a sufficient showing under Wilt and Gentry to allow the testimony of the causation expert, stating:

Dr. Hussein's proffered opinion that multiple myeloma can result from a trauma was based upon: his extensive treatment of Mr. Wiseman; his treatment of five other patients at the Cleveland Clinic who had trauma-induced myelomas; his study of the

319 State ex rel Weirton Med. Ctr. v. Mazzone, No. 30360, 2002 W. Va. LEXIS 97 (June 19, 2002); Daniel v. Charleston Area Med. Ctr., Inc., 544 S.E.2d 905 (W. Va. 2001); Short v. Appalachian OH-9, Inc., 507 S.E.2d 124 (W.Va. 1998); Bellomy, 888 F. Supp. at 760; State v. McKenzie, 475 S.E.2d 521 (W. Va. 1996).

320 For some general references to the Daubert standards, see Katerina M. Eftimoff, The Decade After Daubert Proves Tough on Expert Witnesses, 27 LITIG. NEws 1 (July 2002) (publication of the American Bar Association Litigation Section); Joe S. Cecil, Inconsistency in Evidentiary Standards for Medical Testimony: Disorder in the Courts, 288 JAMA 1382-1387 (2002) (Federal Judicial Center Report); Ron Nichwolodoff, Expert Psychological Opinion Evidence in the Courts, 6 HEALTH L.J. 279 (1998) (examining Daubert from the context of Canadian law).

569 S.E.2d 204 (W. Va. 2002).

443 S.E.2d 196 (W. Va. 1993).

466 S.E.2d 171 (W. Va. 1995).

569 S.E.2d at 207.

Id. at 208. 
physiological process of tissue injury causing chronic inflammation and overstimulation of cells, which triggers the growth of cancerous cells; his interaction with other specialists who also believe that trauma can trigger the occurrence of myeloma; and the handful of published studies by other cancer centers that have identified local tissue injury, including a bone fracture, as a risk factor for causing multiple myeloma.

The supreme court limited the use of nurse testimony to provide the necessary expert causation testimony in Short v. Appalachian $\mathrm{OH}-9 .{ }^{327}$ The supreme court upheld summary judgment, finding that the circuit court acted within its discretion in determining that appellant's disclosed nursing expert was not qualified to offer causation testimony. ${ }^{32}$

The issue of proximate cause was further discussed by the court in Foster v. Sakhai, ${ }^{329}$ where the following instruction was given by the circuit court:

It follows then, to recover from Dr. Sakhai, Mrs. Foster must prove, by a preponderance of the evidence, that Dr. Sakhai's negligence proximately caused Mr. Foster's injury. If, from a preponderance of the evidence, you find that Dr. Sakhai's treatment of Mr. Foster was not the proximate cause of the injury, then you must find for Dr. Sakhai ....

If you find, by a preponderance of the evidence, that Mr. Foster's injury resulted from a proximate cause or causes over

\begin{abstract}
326
Id. at 209-10. Justice Maynard dissented, finding the circuit court did not commit a clear legal error justifying the issuance of a writ. He also reviewed the Wilt/Gentry factors, concluding the trial court correctly excluded the testimony. He challenged whether the testimony about six similar cases was a representative scientific sample, and whether the expert's opinions had been subject to peer review or whether the error rate was known. Moreover, he pointed out that the theory was not generally accepted. Id. at 210-11 (Maynard, J., dissenting); see also State v. Leep, 569 S.E.2d 133 (W. Va. 2002) (analyzing the admissibility of chlamydia testing; extensive discussion of Frye/Wilt/Daubert; emphasizing the role of cross-examination in ferreting out weakness in expert testimony). Leep also held the judge's remarks to the jury that the testing had already been approved by the court were improper: "As a general rule, West Virginia courts are not permitted to comment on the weight of the evidence[.]" Id. at 146 (quoting in part Syl. Pt. 3, State v. Spadafore, 220 S.E.2d 655 (W. Va. 1975)). "A trial judge should not comment on the weight of evidence bearing upon any factual matters to be submitted to the jury for decision. A violation of this general rule may constitute reversible error." Id. at 146 (quoting Syl. Pt. 2, State v. Crockett, 265 S.E.2d 268 (W. Va. 1979)). In light of the dangers inherent in expert scientific testimony, "it is .. . important when scientific evidence is involved in such a proceeding, that the trial judge be especially careful to display an aura of neutrality." Id. at 147 . Concerned that the judge's comments failed in this regard, the jury verdict was overturned. Id.
\end{abstract}

507 S.E.2d 124 (W. Va. 1998).

Id. at 126. 
which Dr. Sakhai had no control or for which he is not responsible, your verdict may be for Dr. Sakhai. ${ }^{330}$

After a verdict for the plaintiff, the circuit court granted a new trial for the defendant, finding in part that the jury instruction was confusing because of the use of the words "may" and "must." 331 The supreme court reversed and reinstated the verdict, finding "it hard to imagine that any juror had such a firm and complete grasp upon the facts of the case, every word of the jury charge, and the Queen's English that he or she, upon hearing the word 'may' saw a golden opportunity to treat Dr. Sakhai unfairly."332

Another significant causation issue arises when there is successive negligence of health care providers. A negligent health care provider is liable for the aggravation of injuries resulting from subsequent negligent medical treatment, if foreseeable, where that subsequent medical treatment is undertaken to mitigate harm caused by the first provider's negligence. ${ }^{333}$ "The relationship between the harm inflicted by the first physician and the treatment initiated by the second is crucial to holding the first physician liable for subsequent malpractice." 334

In Rine v. Irisari, ${ }^{335}$ the court ruled that the jury had not been fully instructed on this issue and determined that the following instruction should have been given to the jury:
$330 \quad$ Id. at 64 (emphasis added by supreme court).
331
Id. at 59,64 .
332
$I d$. at 64 . The court restated in Foster its general view of appellate review of jury instruc- tions, stating:

\begin{abstract}
The formulation of jury instructions is within the broad discretion of a circuit court, and a circuit court's giving of an instruction is reviewed under an abuse of discretion standard. A verdict should not be disturbed based on the formulation of the language of the jury instructions so long as the instructions given as a whole are accurate and fair to both parties.
\end{abstract}

Id. (quoting Syl. Pt. 6, Tennant v. Marion Health Care Found., 459 S.E.2d 374 (W. Va. 1995)). The Foster court's determination that juries are not confused by the use of words "may" and "must" contrasts in a sense with its examination of language in Butcher v. Miller, 569 S.E.2d 89 (W. Va. 2002), where it reversed the defendant's license suspension for drunk driving because of his refusal to submit to a breathalyzer. In Butcher, the defendant refused a breathalyzer test after being informed refusal "may" result in the loss of his license. Id. at 90 . Strictly applying West Virginia Code section 17C-5-7(a), which states the officer must inform the arrestee that refusal to take a breathalyzer "will" result in a license suspension, the court found the use of "may" did not substantially comply with the statute's terms. Butcher, 569 S.E.2d at 93; see also Hanson v. Miller, 567 S.E.2d 687 (W. Va. 2002) (single test breathalyzer test admissible).

333 Syl. Pt. 1, Rine v. Irisari, 420 S.E.2d 541 (W. Va. 1992); Syl. Pt. 3, Thornton v. Charleston Area Med. Ctr., 213 S.E.2d 102 (W. Va. 1975).

334 Rine, 420 S.E.2d at 544 (quoting Daly v. United States, 946 F.2d 1467, 1471 (9th Cir. 1991)). 
You are instructed that if you find [the defendant physician] negligent, then it is not a defense for him nor can he avoid liability for aggravation of the injuries caused by medical personnel who later negligently treated [the patient] for the injuries he received as a result of the original negligence of Defendant .

Any reduction in the amount of damages as a result of other persons' negligence, if any, will be done by me, if the law so provides, after the verdict. It is therefore important that you assess the total amount of damages, if any, according to these instructions. $^{336}$

The court clearly applies this aggravation of injuries rule to a physician whose original negligence causes the intervention of a second physician who is negligent. Significant is the fact the second physician in Rine settled with the plaintiffs, and the first physician had to absorb his negligence at trial.

Another significant causation issue in MPLA actions is the "loss of chance" or "value of chance" doctrine. ${ }^{337}$ This doctrine attempts to hold a healthcare provider responsible for depriving a patient of a chance of recovery or survival due to a breach of the standard of care, thereby decreasing the patient's chance of survival or causing the patient's death. The doctrine offers a theory of recovery based on the loss of the opportunity to recover from an illness. ${ }^{338}$

In Thornton v. Charleston Area Medical Center, ${ }^{339}$ the court recognized that the leading decision concerning the "value of chance" theory as applied in medical malpractice cases is Hicks $v$. United States ${ }^{340}$ In Hicks, a physician who diagnosed gastroenteritis was found negligent for his failure to properly diagnose and treat a patient who died from an intestinal obstruction. The Hicks court applied the "value of chance" theory "because the medical experts who testified at the trial stated that if the patient had been properly diagnosed she would have recovered from the illness." ${ }^{341}$ The court then concluded that the physician's negligence "nullified whatever chance of recovery she might have had and was the proximate cause of the death.",342

$336 \quad$ Id. at $546 \mathrm{n} .9$.

337 In West Virginia, the "loss of chance" doctrine is also referred to as the "value of chance" doctrine. See Thomton v. Charleston Area Med. Ctr., Inc., 305 S.E.2d 316, 323 (W. Va. 1983).

$338 \quad I d$.

339305 S.E.2d 316 (W. Va. 1983).

340368 F.2d 626 (4th Cir. 1966).

341 Thornton, 305 S.E.2d at 323 (citing Hicks, 368 F.2d at 633).

342

Hicks, 368 F.2d at 633. 
The Thornton court stated that the general purpose of the value of chance doctrine is to further elaborate the proximate cause theory in medical malpractice cases. The court followed the Pennsylvania Supreme Court's reasoning in Hamil v. Baseline, ${ }^{343}$ which relied on the Restatement (Second) of Torts section 323(a) in addressing the issue. ${ }^{344}$ The Hamil court noted that the Restatement section allows the issue of medical malpractice to go to the jury on a lower than normal threshold of proof. ${ }^{345}$ In Thornton, the plaintiff suffered a fracture of his right leg in a motorcycle accident. He was hospitalized at CAMC and subsequently underwent medical treatment for four years. Ultimately, the plaintiff had to have his right leg amputated below the knee. The plaintiff's theory was that the original leg injury had been improperly treated, which aggravated the injury and thus necessitated the amputation. ${ }^{346}$ The defendant asserted that the original injury was so severe that amputation would have resulted regardless of his treatment.

The "value of chance" theory was applied to the plaintiff's claim that the physician's negligence took away any chance of the right leg healing properly, and thus proximately caused the amputation. The court recognized that the issue was one of causation and addressed whether the physician's action or inaction increased risk of the amputation, and was a substantial factor in the amputation of the plaintiff's leg. ${ }^{347}$

\section{Summary Jury Trial}

House Bill 601 adds a new provision allowing the circuit court to order a "summary jury trial . . . if all parties represent a case is ready for trial and jointly move the court for a summary jury trial . . ." S448 Summary jury trials, as described in section 55-7B-6c, are designed in a streamlined format which allows the presentation of evidence by counsel for the parties without calling witnesses.

$343 \quad 392$ A.2d 1280 (Pa. 1978).

344 Section 323 of the RESTATEMENT (SECOND) OF TORTS (1965) states:

One who undertakes, gratuitously or for consideration, to render services to another which he should recognize as necessary for the protection of the other's person or things, is subject to liability to the other for physical harm resulting from his failure to exercise reasonable care to perform his undertaking if (a) his failure to exercise such care increases the risk of such harm, or (b) the harm is suffered because of the other's reliance upon the undertaking.

345 Hamil, 392 A.2d at 1287-88.

346 Thornton, 305 S.E.2d at 323.

347 Id.; see also Syl. Pt. 1, Hudnall v. Mate Creek Trucking, Inc., 490 S.E.2d 56 (W. Va. 1997); Shia v. Chvasta, 377 S.E.2d 644 (W. Va. 1988); Syl. Pt. 6, Catlett v. MacQueen, 375 S.E.2d 184 (W. Va. 1988).

W. VA. CODE § 55-7B-6b(d) (2001). 
In other jurisdictions, the purpose of the summary jury trial is to attempt settlement of disputes. ${ }^{349}$

A summary jury trial is a non-binding proceeding that encourages settlement. The trial usually lasts less than a full day .... Generally, six jurors are chosen after a brief voir dire conducted by the court. Following short opening statements, the attorneys present the evidence to the jury. Live witnesses do not testify, and evidentiary and procedural rules are few and flexible. After the attorneys' presentations, the jury is given an abbreviated charge and is requested to return a unanimous verdict. If the jurors cannot reach a consensus, they are asked to return a special verdict, listing individual perceptions of liability and damages. The special verdict affords counsel insights as to lay perceptions of the case and aids arriving at an equitable basis for settlement. ${ }^{350}$

Summary jury trials are held before a six person jury, generally last no more than one day, ${ }^{351}$ and consist of the presentation of evidence by counsel for the parties, based on "pleadings, depositions, or other discovery requests and responses, exhibits and statements of potential witnesses."352 Unless the court orders otherwise, each party has one hour to present its case, and where there are multiple parties, the court shall make reasonable adjustment of the time allowed. ${ }^{353}$

Section 55-7B-6c(d) expressly provides:

349 See Cincinnati Gas \& Elec. Co. v. Gen. Elec. Co., 854 F.2d 900, 902 n.l (6th Cir. 1988).

350 Arabian Am. Oil Co. v. Scarfone, 939 F.2d 1472 (11th Cir. 1991) (citing Thomas D. Lambros, The Summary Jury Trial and Other Altemative Methods of Dispute Resolution, A Report to the Judicial Conference of the United States Committee of the Operation of the Jury System, 103 F.R.D. 461, 483-84 (1984)); see also Russell v. PPG Industries, Inc., 953 F.2d 326, 334 (7th Cir. 1992). The idea for summary jury trials was advanced in 1980 . Lambros, supra note 350, at 463; see John F. Wagner, Jr., Validity and Effect of Local District Court Rules Providing for Use of Alternative Dispute Resolution Procedures as Pretrial Settlement Mechanisms, 86 A.L.R. FED 211 (1992); Gitchell \& Plattner, supra note 203, at 457. Some courts hold Rule 16 of the Federal Rules of Civil Procedure does not provide for mandatory summary jury trials. See In re NLO, Inc., 5 F.3d 154 (6th Cir. 1993); Strandell v. Jackson County, 838 F.2d 884 (7th Cir. 1987). But see McKay v. Ashland Oil, Inc., 120 F.R.D. 43, 48 (E.D. Ky. 1988) ("[M]andatory summary jury trials would seem to be within the inherent power of the court."); Lambros, supra note 350, at 469 (summary jury trial within court's inherent power). Courts have ruled that since summary trials are a means to settlement, they are confidential, and the press and non-parties had no right to attend. See In re Cincinnati Enquirer, 94 F.3d 198 (6th Cir. 1996); In re Voinovich, 92 F.3d 383 (6th Cir. 1996); $c f$. B.H. v. McDonald, 49 F.3d 294 (7th Cir. 1995).

W. VA. CODE $\S 55-7 B-6 c(a)$ (Supp. 2002).

Id. § 55-7B-6c(e). 


\begin{abstract}
No potential testimony of a witness may be referred to unless the reference is based on: (i) The product of discovery procedures; (ii) a written sworn statement of the witness; or (iii) an affidavit of counsel stating that although an affidavit of the witness is not available and cannot be obtained by the exercise of reasonable diligence, the witness would be called at trial and counsel has been told the substance of the testimony of the witness. The substance of the witness' testimony must also be included in the affidavit of counsel. ${ }^{354}$
\end{abstract}

Counsel may object to presentations that violate subsection (d) or which go beyond the limits of propriety in statements about the evidence or otherwise. ${ }^{355}$

As to instructions and jury deliberations, section 55-7B-6c(g) states:

Following the presentations by counsel, the court shall give an abbreviated set of instructions to the jury on the applicable law. The jury will be encouraged to return a verdict that represents a unanimous verdict of the jurors. If after a reasonable time a unanimous verdict is not possible, the jury shall be directed to return a special verdict consisting of an anonymous statement of each juror's finding on liability and damages. Following the verdict, the court may invite, but may not require, the jurors to informally discuss the case with the attorneys and the parties. ${ }^{356}$

Summary jury proceedings are not recorded unless a party makes the arrangements at its own expense. Statements in briefs or summaries, statements of counsel and the verdict are not admissible in any evidentiary proceeding. ${ }^{357}$

Within thirty days of the verdict, the parties must file a notice stating whether they accept or reject the summary trial verdict. ${ }^{358}$ If all parties accept, then the verdict is to be reduced to judgment by the court. If one party rejects, the case then proceeds in the normal fashion to trial. However, a rejecting party must later win to avoid the imposition of sanctions. ${ }^{359}$ Section 55-7B-6(c) pro-

\begin{tabular}{ll}
\hline 354 & Id. $855-7 \mathrm{~B}-6 \mathrm{c}(\mathrm{d})$. \\
355 & Id. $\S 55-7 \mathrm{~B}-6 \mathrm{c}(\mathrm{f})$. \\
356 & Id. \\
357 & Id. $\S 55-7 \mathrm{~B}-6(\mathrm{c}),-6(\mathrm{~h})$. \\
358 & Id. $\S 55-7 \mathrm{~B}-6(\mathrm{c})$. \\
359 & Id. The statute states:
\end{tabular}

If a verdict is rendered upon the subsequent trial of the case which is not more than twenty percent more favorable to a party who rejected the summary jury trial verdict and indicated a desire to proceed to trial, the rejecting party is liable for the costs incurred by the other party or parties subsequent to the 
vides that the plaintiff who loses a summary trial must win at the "real" trial or obtain a verdict at least $20 \%$ larger than the summary trial verdict, or be liable for costs and attorneys' fees for the defense. Conversely, the defendant who proceeds against an adverse verdict must either win or lessen his or her liability by at least $20 \%{ }^{360}$

The liability for attorneys' fees is significant to both sides, as it puts "teeth" into the decision to proceed in the face of an adverse summary trial verdict. Other sanctions provisions in the MPLA do not include, and in fact exclude, attorneys' fees as a sanction. ${ }^{361}$ This provision probably means that summary trial will be used sparingly, and most likely as a tool for settlement. Indeed, to the extent the summary trial provision is designed to give the parties an opportunity to "test" a case in an effort to further settlement, the attorneys' fees provisions probably discourage, rather than encourage, its use.

\section{J. $\quad$ Assorted Trial Issues}

West Virginia Code section 55-7B-6b(c) requires the circuit court to enter a scheduling order which sets a trial date within 24 months from the date the defendant made an appearance, or in cases of multiple defendants, within 24 months of the last defendant's appearance. The trial date "shall be adhered to unless, for good cause shown, the court enters an order continuing the trial date."362

The supreme court has addressed various trial evidence issues. In Hicks v. Ghaphery, the court held that the Dead Man's Statute does not apply to MPLA actions. ${ }^{363}$ Thus, "[West Virginia] Code [section] 57-3-1 (1937) does

summary jury trial, in a similar manner as is provided in rule $68(\mathrm{c})$ of the rules of civil procedure when a claimant rejects an offer of judgment, and is liable for attorneys' fees incurred after the summary jury trial.

Id.

360 This provision suggests a couple of interesting issues which may ultimately be resolved by the courts. The "twenty percent more favorable" language is easy when you simply consider money damages. If a single plaintiff increased or a single defendant reduced a verdict $20 \%$, then the statute would seem to be satisfied. More complex, perhaps, are multi defendant cases where "twenty percent more favorable" could be interpreted to apply to a reduction in a defendant's relative share of the verdict. For example, a defendant could lose the summary trial, but decrease its liability by $20 \%$, and not be liable for costs and fees. Another interesting issue is where, in a multiple defendant case, a defendant is successful in reducing its liability below $25 \%$, making its liability several only, and perhaps reducing its ultimate share more than $20 \%$.

361 Existing provisions of the MPLA allow the imposition of sanctions, but exclude attorneys' fees. See W. VA. CODE $\S 55-7 B-6(b)$ (Supp. 2002).

$362 I d . \$ 55-7 \mathrm{~B}-6 \mathrm{~b}(\mathrm{c})$. For a case discussing the circuit court's power as it relates to scheduling and bifurcation, see State ex rel. Shelton v. Burnside, No. 30671, 2002 WL 31465717 (W. Va. Nov. 4, 2002). 
not bar any party in a wrongful death, medical malpractice action from testifying about conversations with the deceased patient. ${ }^{364}$ It was appropriate, therefore, to allow the physician to testify about treatment recommendations he made to the decedent. ${ }^{365}$ Moreover, statements made for purposes of medical treatment are admissible under Rule 803(4) of the West Virginia Rules of Evidence. ${ }^{366}$

In Hicks, the court also held that it was not an abuse of discretion for the court to preclude cross-examination of a physician about prior malpractice actions. ${ }^{367}$ The plaintiff argued that the defendant physician's attempt to portray himself as one of the best doctors in the area and country "opened the door" for such cross examination. Since the circuit court gave a strong instruction to the jury to disregard the "best doctor" testimony, the supreme court found no abuse of discretion. ${ }^{368}$

Improper statements by counsel which violate an in limine motion may or may not result in reversal. ${ }^{369}$

K. Jury

West Virginia Code section 55-7B-6d provides for twelve jurors instead of six in MPLA cases, and for a verdict based on a majority of nine. ${ }^{370}$ "The

364

365

Id. at 330 .

Id. The Hicks court discussed at length its reasoning, concluding:

In light of the distinctive provisions of the MPLA and considering the continually evolving nature of the common law, we believe it is necessary to carve out a narrow exception to the Dead Man's Statute which limits its applicability in medical malpractice cases. Specifically, we believe that no party should be prohibited from offering evidence in a medical malpractice case because of the Dead Man's Statute. Obviously, the focus of a medical malpractice case is the care and treatment of the patient. In the instance where the patient is deceased, it would be patently unfair to exclude evidence of a patient's complaints regarding their symptoms and ailments and their decisions as to what type of treatment they wished to undergo. In some cases, a patient's subjective description of their ailments may be the sole basis for a physician's diagnosis and treatment.

Id. at 329.

366 See State v. Pettry, 549 S.E.2d 323, 336 (W. Va. 2001) (Starcher, J., concurring).

367571 S.E.2d at 326 (noting that curative instruction was sufficient even though doctor had portrayed himself "as one of the best doctors in the area, as well as in America").

368 Id.

369 Compare Honaker v. Mahon, 552 S.E.2d 788 (W. Va. 2001), with Foster v. Sakhai, 559 S.E.2d 53 (W.Va. 2001), and Roberts v. Stevens Clinic Hosp. Inc., 345 S.E.2d 791 (W. Va. 1986); see also Matheny v. Fairmont Gen. Hosp., No. 30256, 2002 WL 31746852 (W. Va. Dec. 6, 2002) (noting that counsel made appropriate causation argument in closing argument, not improper contributory negligence argument). 
judge shall instruct the jury that they should endeavor to reach a unanimous verdict but, if they cannot reach a unanimous verdict, they may return a majority verdict of nine of the twelve members of the jury."371 The court must accept a nine-member verdict, but all concurring jurors must sign the verdict form. The verdict must be announced in open court by either the judge or the foreman, and the jury shall be polled at the request of any party or the court. If polling shows nine members do not concur, they are to retire for further deliberations. ${ }^{372}$

Section 56-6-12 provides for voir dire of jurors to determine whether they can fairly judge a particular case. If "it shall appear to the court that such person is not a qualified juror or does not stand indifferent in the cause, another shall be called and placed in his stead for the trial of that cause., ${ }^{373}$ In $O^{\prime}$ Dell $v$. Miller, ${ }^{374}$ the court stated:

The object of jury selection is to secure jurors who are not only free from improper prejudice and bias, but who are also free from the suspicion of improper prejudice or bias. Voir dire ferrets out biases and prejudices to create a jury panel, before the exercise of peremptory strikes, free of the taint of reasonably suspected prejudice or bias. Trial courts have an obligation to strike biased or prejudiced jurors for cause. ${ }^{375}$

Doubts should be resolved in favor of the party seeking to strike the juror for cause. Even where a juror claims impartiality, other statements must be considered on the issue as well as hospital employment, medical background and relationship with defendant. ${ }^{376}$ In MPLA actions, an important factor to be considered is the juror's relationship with the defendant health care provider. Where there is a physician-patient relationship between a juror and defendant, even in the past, or an attorney-client relationship between the juror and counsel for one of the parties, the court should strike the juror. ${ }^{377}$

W. VA. CODE $\S 55-7 B-6 d(2002) ;$ see also W. VA. CODE $§ 56-6-11$ (2002) (reflecting the change to the nine-twelve jury system).

W. VA. CODE $§ 55-7 B-6(d)$.

372

ld.

373

Id. § 56-6-12 (2002).

374

565 S.E.2d 407 (W. Va. 2002).

375

Id. at $\mathbf{4 1 0}$ (juror who was a former patient of the defendant physician, and realized action could affect his practice, and was a current client of the defendant's law firm should have been struck for cause).

See Rine v. Irisari, 420 S.E.2d 541 (W. Va. 1992); see also W. Va. Dept. of Highways v. Fisher, 289 S.E.2d 213 (W. Va. 1982).

377 See O'Dell, 565 S.E.2d at 407 ("Any doubt the court might have regarding the impartiality of a juror must be resolved in favor of the party seeking to strike the potential juror.") (citation 


\section{L. $\quad$ Comparative Fault, Joint \& Several Liability, Third Party and Settle- ment Issues}

Generally, West Virginia follows a modified system of comparative causation. A plaintiff is barred from recovery if his negligence equals or exceeds $50 \%$ of the combined negligence or fault of all parties to an accident. ${ }^{378}$ The jury assesses the fault of all the parties. ${ }^{379}$ Defendants have a right to contribution from other negligent parties. Issues of comparative fault and contributory negligence are generally for resolution by the jury. In Raines $v$. Lindsey, ${ }^{380}$ the court stated that in

a comparative negligence or causation action the issue of apportionment of negligence or causation is one for the jury or other trier of the facts, and only in the clearest of cases where the facts are undisputed and reasonable minds can draw but one inference from them should such issue be determined as a matter of law. The fact finder's apportionment of negligence or causation may be set aside only if it is grossly disproportionate. ${ }^{381}$

The MPLA modifies the comparative causation scheme. West Virginia Code section 55-7B-9(a) requires the jury, in trials involving multiple defendants, to allocate percentages of fault among parties to the injury. Then, section 55-7B-9(b) states that

in every medical professional liability action, the court shall make findings as to the total dollar amount awarded as damages to each plaintiff. The court shall enter judgment of joint and several liability against every defendant which bears $25 \%$ or more of the negligence attributable to all defendants. The court

omitted); see also Doe v. Wal-Mart Stores, Inc., 558 S.E.2d 633 (W. Va. 2002); Phares v. Brooks, 566 S.E.2d 233 (W. Va. 2002); State v. Johnson, 565 S.E.2d 415 (W. Va. 2002); Davis v. Wang, 400 S.E.2d 230, 234 (W. Va. 1990), overruled on other grounds by Pleasants v. Alliance Corp., 543 S.E.2d 320 (W. Va. 2000); State v. West, 200 S.E.2d 859, 866 (W. Va. 1973). When an attorney learns of information that would disqualify a juror, the issue must be brought to the attention of the trial court as soon as possible, Syl. Pt. 5, McGlone v. Superior Trucking, Inc., 363 S.E.2d 736 (W. Va. 1987), unless the information is such that when discovered, nothing could have been done. State v. Vamer, No. 30658, 2002 WL 31519686 (W. Va. Nov. 8, 2002) (noting that motion for new trial was not untimely because juror's false answers to voir dire questions were not discovered until trial was over).

378 Bradley v. Appalachian Power Co., 256 S.E.2d 879 (W. Va. 1979).

379 Bowman v. Barnes, 282 S.E.2d 613 (W. Va. 1981).

380423 S.E. $2 d 376$ (W. Va. 1992).

381 Id. at 379; see also Biddle v. Haddix, 179 S.E.2d 215 (W. Va. 1971); Wilson v. Edwards, 77 S.E.2d 164 (W. Va. 1953); Miller v. Blue Ridge Transp. Co., 15 S.E.2d 400 (W. Va. 1941). 
shall enter judgment of several, but not joint, liability against and among all defendants which bear less than $25 \%$ of the negligence attributable to all defendants. ${ }^{382}$

The jury's verdict setting the percentages of negligence among defendants is binding as to their rights of contribution. ${ }^{383}$ The $25 \%$ rule applies only to the defendants in an MPLA action and does not apply to non-party tortfeasors unless there is evidence of contributory negligence by the plaintiff. ${ }^{384}$ West Virginia Code section 55-7B-9 is consistent with general West Virginia law which allows a plaintiff to sue any or all of those responsible for his injuries and collect his damages from whomever is able to pay, regardless of the percentage of fault. ${ }^{385}$

West Virginia places a heavy burden on defendants seeking to establish contributory negligence by the plaintiff, as demonstrated by Rowe v. Sisters of the Pallotine Missionary Society. ${ }^{386}$ Rowe involved failure to diagnose a compartment syndrome. The plaintiff settled with the doctor and went to trial against the hospital, arguing the nurses failed to advocate for the patient in light of his symptoms. Rowe has several significant holdings. First, the supreme court concluded that "a health care provider is not entitled to a comparative negligence instruction requiring a jury to consider the plaintiff's negligent conduct that triggered the plaintiff's need for medical treatment."

W. VA. CODE $\S 55-7 B-9$ (c) (2002) states:

Each defendant against whom a judgment of joint and several liability is entered in a medical professional liability action pursuant to subsection (b) of this section is liable to each plaintiff for all or any part of the total dollar amount regardless of the percentage of negligence attributable to him. The right of contribution exists in favor of each defendant who is paid to a plaintiff more than a percentage of the total dollar amount awarded attributable to him relative to the percentage of negligence attributable to him. The total amount of recovery for contribution is limited to the amount paid by the defendant to a plaintiff in excess of the percentage of the total dollar amount awarded attributable to him. No right of contribution exists against any defendant who entered into a good faith settlement with the plaintiff prior to the jury's report of its findings to the court or the court's findings as to the total dollar amount awarded as damages.

Id. $§ 55-7 \mathrm{~B}-9(\mathrm{~d})$.

384 Rowe v. Sisters of the Pallotine Missionary Soc., 560 S.E.2d 491 (W. Va. 2001). In Rowe, the court stated: "Consequently, without some proof of negligence by the plaintiff, there is no requirement that the jury be instructed to ascertain or apportion fault between the defendant and a non-party tortfeasor." Id. at 499.

385 Teter v. Old Colony Co., 441 S.E.2d 219 (W. Va. 1994); Kodym v. Frazier, 412 S.E.2d 219 (W. Va. 1991).

560 S.E.2d 491 (W. Va. 2001).

Id. at 497. 
Plaintiffs who negligently injure themselves are entitled to subsequent, non-negligent medical treatment. If a health care provider renders negligent medical treatment, regardless of the event that triggered the need for medical treatment, plaintiffs are entitled to an undiminished recovery in a tort action for any damages proximately caused by that negligent medical treatment. $^{388}$

As to plaintiff's comparative fault, the Rowe court noted that "[i]n the context of medical malpractice actions, courts usually place extreme limits upon a health care provider's use of the defense of comparative negligence." 389 Thus,

[c]ontributory negligence on the part of the plaintiff is an affirmative defense. There is a presumption of ordinary care in favor of the plaintiff, and where the defendant relies upon contributory negligence, the burden of proof rests upon the defendant to show such negligence unless it is disclosed by the plaintiff's evidence or may be fairly inferred by all of the evidence and circumstances surrounding the case. ${ }^{390}$

Accordingly, in West Virginia, "the health care provider must prove, with respect to plaintiff's conduct after medical treatment is initiated, that: (1) the plaintiff owed himself a duty of care; (2) the plaintiff breached that duty; and (3) the breach was a proximate cause of the damages the plaintiff sustained."391

Significantly, the Rowe court also ruled that the jury did not have to be instructed to consider the negligence of the settling physician.

[T] he comparative negligence doctrine applies only when a plaintiff has been contributorily negligent - the negligence of the plaintiff in causing his or her injury is ascertained in relation to all other tortfeasors.

Consequently, without some proof of negligence by the plaintiff, there is no requirement that the jury be instructed to ascertain or apportion fault between the defendant and a nonparty tortfeasor. ${ }^{392}$

\begin{tabular}{ll}
\hline 388 & Id. \\
389 & Id. \\
390 & Id. at 498. \\
391 & Id.; see also Judy v. Grant County Health Dept., 577 S.E.2d. 340 (W. Va. 2001). \\
392 & Rowe, 560 S.E.2d at 499 (footnotes omitted).
\end{tabular}


The Rowe court also held that the MPLA's $25 \%$ rule only applies to parties in the case at the time of verdict, stating that the physician "had settled and was dismissed from the action, and none of the other alleged tortfeasors was brought into the litigation, by either the appellee or the appellant. [The physician] and the other alleged tortfeasors were not 'defendants' in the trial." Therefore, in the vast majority of cases, the plaintiff chooses whom to settle with and proceeds to trial against others without limitation, thereby increasing the pressure on non-settling parties to settle.

In several opinions, the supreme court has severely limited the "empty chair" defense, i.e., the ability of defendants to argue the negligence of an absent party. ${ }^{394}$ The "empty chair" prohibition, however, does not proscribe arguments based on causation. In Matheny v. Fairmont General Hospital, ${ }^{395}$ the court held that defense counsel's statements in closing argument asserting that the patient's injuries resulted from failure to promptly seek treatment did not improperly suggest contributory negligence.

In order to seek contribution and indemnity from non-parties, it appears defendants must bring them into the action by third party claim. In Howell $v$. Luckey ${ }^{396}$ the court held a defendant cannot seek contribution in a separate action after losing a jury verdict. Instead, the alleged negligent non-party must be joined by a third party action. ${ }^{397}$ Likewise, in Wilkinson $v$. Duff, ${ }^{398}$ the court affirmed summary judgment for a pharmaceutical manufacturer on a physician's third party claim.

Woodrum v. Johnson ${ }^{400}$ is an important opinion concerning settlement with an agent and its effect on the principal. The court held:

A plaintiff's voluntary settlement with and release of a defendant who is primarily liable for the plaintiff's injury does not operate to release parties defendant whose liability is vicarious or derivative based solely upon their relationship with the settling defendant. ${ }^{401}$

Id. at 500 .

See Doe v. Wal-Mart Stores, Inc., 558 S.E.2d 663 (W. Va. 2001).

No. 30256, 2002 W. Va. LEXIS 233 (Dec. 6, 2002).

518 S.E.2d 873 (1999).

397

Id. at 877 .

No. 30399, 2002 W. Va. LEXIS 236 (Dec. 5, 2002).

For a discussion of Wilkinson, see supra notes 145 to 152 and accompanying text. 
In Woodrum, the plaintiff sued the defendant surgeon (and the hospital under ostensible agency theory) for negligently failing to diagnose and treat an infection. ${ }^{402}$ After discovery, the plaintiff reached a confidential settlement with the physician for less than his policy limits, specifically reserving the plaintiff's right to proceed against the hospital. The plaintiff refused to disclose the amount of the settlement, except to admit it was below the physician's policy limits. The plaintiff also refused to dismiss the hospital. ${ }^{403}$

The hospital moved for summary judgment, asserting that the release of the agent releases the principal where the allegations are solely based on ostensible agency. ${ }^{404}$ Despite law from other jurisdictions supporting the hospital, the circuit court denied the motion, and certified the following question, which the supreme court answered in the negative:

Does the settlement with and release of a physician, who is an alleged ostensible agent of a hospital, necessarily release the hospital from further liability for the alleged malpractice of the physician where: (1) the physician is not an employee of the hospital; (2) the only negligence alleged is that of the physician; and (3) there is no allegation of negligence against the hospital ${ }^{405}$

Woodrum is a fairly confusing opinion in which the supreme court based on West Virginia Code section 55-7-12 and dicta from a 1953 West Virginia case - concluded that principals are simply joint tortfeasors with their agents. $^{406}$ Noting that a plaintiff can sue a principal without suing the agent and dismiss a sued agent without releasing the principal, the court stated:

402 Id. at 910 . The defendant physician was a surgeon, but according to the supreme court, the plaintiff sought to hold the hospital liable for his actions under Torrence v. Kusminsky, 408 S.E.2d 684 (W. Va. 1991). Woodrum, 559 S.E.2d at 910. The court did not analyze why the hospital was liable for the surgeon.

$403 \quad$ ld.

$404 \quad I d$.

$405 \quad$ Id. at 909.

406 Id. at 911-12. The court analyzes Bumgarner v. Sims, 79 S.E.2d 277 (W. Va. 1953), as suggesting that the liability of principals and agents is joint, meaning release of one does not release the other. Woodrum, 559 S.E.2d at 911 . Even while declaring this analysis as being based on dictum, the court states "thus, on stare decisis grounds, we would be hard pressed to disregard the relevant statement in Bumgarner as dictum." Id. at 912. The statement footnotes Dailey $v$. Bechtel Corp., 207 S.E.2d 169 (W. Va. 1974):

Stare decisis is not a rule of law but is a matter of judicial policy. . . . It is a policy which promotes certainty, stability and uniformity in the law. It should be deviated from only when urgent reason requires deviation. . . . In the rare case when it clearly is apparent that an error has been made or that the application of an outmoded rule, due to changing conditions, results in injustice, deviation from that policy is warranted. 
It would be peculiar indeed if we were to allow a plaintiff to gratuitously dismiss a primarily liable tortfeasor without consequence to the right to proceed against a vicariously responsible defendant, but impose the harsh sanction of total preclusion simply because the plaintiff was successful in obtaining some measure of recompense for his or her injuries. ${ }^{407}$

Oddly, the opinion states the hospital has a right of implied indemnity enforceable by cross claim or third party complaint despite the settlement. ${ }^{408}$

In this regard, however, we simply do not see how the Hospital could in any way be prejudiced by a rule which permits plaintiffs to proceed further against it in the present matter. As we have seen, had they chosen, the plaintiffs could have appropriately brought an action solely against the Hospital, or otherwise voluntarily dismissed the defendant physician. Significantly, a vicariously liable defendant's right to implied indemnity is not affected by settlement between a plaintiff and other liable parties. The substantive impact of the settlement agreement in this case is therefore not materially different from what would result if plaintiffs had chosen to utilize procedures that have long been permitted under West Virginia law. ${ }^{409}$

Commenting further, the Woodrum court suggested an indemnity action may be brought in a later action:

This raises the very real possibility, however, that the primarily liable agent will remain liable for the full amount of damages notwithstanding the fact that he or she has settled with the plaintiff. But, "[a]s to any subsequent action by the [principal] against the [agent], '[a] primary wrongdoer enters [settlement]

\footnotetext{
Woodrum, 559 S.E.2d at 913 n.8. Here, stare decisis based on dicta from a 1953 case compelled the court to place liability on hospitals where the specific issue had not been addressed in West Virginia, and where a compelling policy argument can be made that it is unnecessary to impose liability for West Virginia hospitals where physicians settle for less than policy limits. Conversely, in Bradshaw v. Soulsby, 558 S.E.2d 681 (W. Va. 2001), the court completely ignored stare decisis and overruled a 1991 case on point to apply the "discovery rule" to wrongful death actions. See Miller v. Romeo, 413 S.E.2d 178 (W. Va. 1991).
}

$407 \quad 559$ S.E.2d at 914.

408

Id. at 915 .

409

Id. (citing Syl. Pt. 7, Hager v. Marshall, 505 S.E.2d 640 (W. Va. 1998) ("In non-product liability multi-party civil actions, a good faith settlement between a plaintiff and a defendant will extinguish the right of a non-settling defendant to seek implied indemnity unless such non-settling defendant is without fault.")). 
agreements at the peril of being later held to respond again in an indemnification action brought against him by the vicarious wrongdoer." This potentially undesirable consequence can, of course, be avoided by providing in the settlement agreement that the plaintiff will indemnify the settling defendant for any amount that such party may be called upon to pay in excess of the settlement amount. In such case the plaintiff would have little, if any, incentive to continue pursuing a judgment against the derivatively responsible principal, thus effectively bringing the action to a conclusion. ${ }^{410}$

In a footnote, the court referred to indemnity language in the release, suggesting that the plaintiff agreed to indemnify the physician for such claims, thereby potentially resolving the problem. ${ }^{411}$ Thus, Woodrum suggests that where an agent enters into a settlement, the principal has the right, by cross or third party claim, to seek implied indemnity. In other words, settlement does not protect the settling physician unless it includes the hospital alleged to be the principal.

\section{UTPA CLAIMS}

House Bill 601 also changes the law related to the Unfair Trade Practices Act ("UTPA"), under which a statutory claim exists for any party injured as a result of general business practices by insurers which violate the Act. ${ }^{412}$ West Virginia Code section 55-7B-5(b) exempts medical malpractice insurers from claims based on violation of the Act brought by third parties. UTPA actions by insureds are not precluded by the new provision, but cannot be filed until the underlying action is resolved. ${ }^{413}$

Generally, a private cause of action exists for both first and third parties under the UTPA. ${ }^{414}$ Recognizing a private right of action under the statute, the court in Jenkins v. J. C. Penney Cas. Ins. Co. ${ }^{415}$ held that insurers are under an

\footnotetext{
$410 \quad$ Id. at 917 (quotation omitted).

$411 \quad$ Id. at n.11.

412 Generally, a private cause of action exists for both first and third parties under the UTPA. W. VA. CODE $\$ 33-11-4$ (1992). Recognizing a private right of action under the statute, the court in Jenkins v. J. C. Penney Cas. Ins. Co., 280 S.E.2d 252 (W. Va. 1981) (overruled in part by State ex rel. State Farm v. Madden, 451 S.E.2d 721 (W. Va. 1994)), held that insurers are under an obligation to attempt, in good faith, to effectuate prompt, fair and equitable settlement of claims in which liability has become reasonably clear. However, UTPA claims do not apply to self-insured parties. Hawkins v. Ford Motor Co., 566 S.E.2d 624, 629 (W. Va. 2002).
}

\footnotetext{
413 W. VA. CODE $\S$ 55-7B-5(b).

414 W. VA. CODE $§ 33-11-4$ (1992).

415280 S.E.2d 252 (W. Va. 1981).
} 
obligation to attempt, in good faith, to effectuate prompt, fair and equitable settlement of claims in which liability has become reasonably clear. ${ }^{416}$

\section{HoSPITAL LIABILITY ISSUES}

Hospitals and other health care facilities face broad liability despite the reforms set forth in the MPLA. ${ }^{417}$ Like any other employer, hospitals are liable for the actions of employees in the scope of employment. ${ }^{418}$ Hospitals, however, have a unique relationship with physicians who practice within their walls. Physicians, after a credentialing process, are granted privileges as part of the hospital's medical staff. These privileges allow them to admit patients and practice medicine in the hospitals. Generally, hospitals are not liable for the actions of physicians who are members of their medical staff and are treated as independent contractors. ${ }^{419}$ For this reason, hospitals are not liable for the failure of physicians to obtain informed consent. ${ }^{420}$

The liability of hospitals for staff physicians has been expanded in several ways in West Virginia. "Where a patient goes to a hospital seeking medical services and is forced to rely on the hospital's choice of physician to render those services, the hospital may be found vicariously liable for the physician's negligence., ${ }^{, 421}$ In Thomas $v$. Raleigh General Hospital, ${ }^{422}$ the court reversed summary judgment in favor of a hospital where the patient had no choice but to accept the anesthesiologist provided by the hospital. ${ }^{423}$ Similarly, hospitals are

Id. at 258-59. In Syllabus Point 4 of Doddrill v. Nationwide Mutual Insurance Co., 491 S.E.2d 1 (W. Va. 1997), the court stated:

To maintain a private action based upon violations of [West Virginia] Code $\S$ 33-11-4(9), the plaintiff must prove 1) the conduct in question constitutes more than a single violation of [West Virginia] Code $\$ 33-11-4(9) ; 2)$ the violations arise from separate, discrete acts or omissions in the claim settlement; and 3 ) the violations arise from a habit, custom, usage or business policy of the insurer, so that, viewing the conduct as a whole, the finder of fact is able to conclude that the practice or practices are sufficiently pervasive or sufficiently sanctioned by the insurance company so that the conduct can by considered a "general business practice" and not an isolated event.

417 See Thomas J. Hurney, Jr., Hospital Liability in West Virginia, 95 W. VA. L. REV. 943 (1993).

418 See Taylor v. Cabell Huntington Hosp., 538 S.E.2d 719 (W. Va. 2000).

419 Thomas v. Raleigh Gen. Hosp., 358 S.E.2d 222, 225 (W. Va. 1987); Cross v. Trapp, 294 S.E.2d 446, 459 (W. Va. 1982). See generally Annotation, Liability of Hospital or Sanitorium for Negligence of Physician or Surgeon, 51 A.L.R.4th $235 \$ 5$ (1987).

420

Cross, 294 S.E.2d at 459.

421 Thomas, 358 S.E.2d at 225; see also Paintsville Hosp. Co. v. Rose, 683 S.W.2d 255 (Ky. 1985); Clark v. Southview Hosp. \& Family Health Ctr., 628 N.E.2d 46 (Ohio 1994).

358 S.E.2d 222 (W. Va. 1987).

423

Id. at 226. 
generally vicariously liable for the actions of emergency room physicians, regardless of the employment or other relationship the physician has with the hospital:

Where a hospital makes emergency room treatment available to serve the public as an integral part of its facilities, the hospital is estopped to deny that the physicians and other medical personnel on duty providing treatment are its agents. Regardless of any contractual arrangements with so-called independent contractors, the hospital is liable to the injured patient for acts of malpractice committed in its emergency room, so long as the requisite proximate cause and damages are present. ${ }^{424}$

However, ostensible agency has limits. In Hicks v. Ghaphery, ${ }^{425}$ the court affirmed summary judgment for the hospital, rejecting plaintiff's argument that the hospital was vicariously liable for the physician defendant's negligence. In Hicks, the plaintiff was referred to the defendant, who was the on-call physician for the emergency room on April 12, 1996. The alleged negligence, however, occurred four days later during a surgery. Also important to the court's conclusion was the consent form signed by the plaintiff, which stated that physicians providing services were not employees or agents of the hospital. ${ }^{426}$

Advertising may provide the basis for ostensible agency. ${ }^{427}$ In Glover $v$. St. Mary's Hospital of Huntington, ${ }^{428}$ the supreme court reversed summary judgment for the hospital in a wrongful death case, finding a possible issue of fact as to whether the hospital's advertising rendered it liable for the acts of the defendant surgeon. ${ }^{4 \hat{9}}$ The hospital moved for summary judgment after the plaintiff failed to name an expert witness critical of its conduct. ${ }^{430}$ The circuit court granted the motion because the surgeon was not the ostensible agent of the hospital and there was no testimony of independent negligence by the hospital. $^{431}$

The plaintiff appealed, asserting a factual issue about the hospital's vicarious liability because the hospital "held itself out" as providing the services

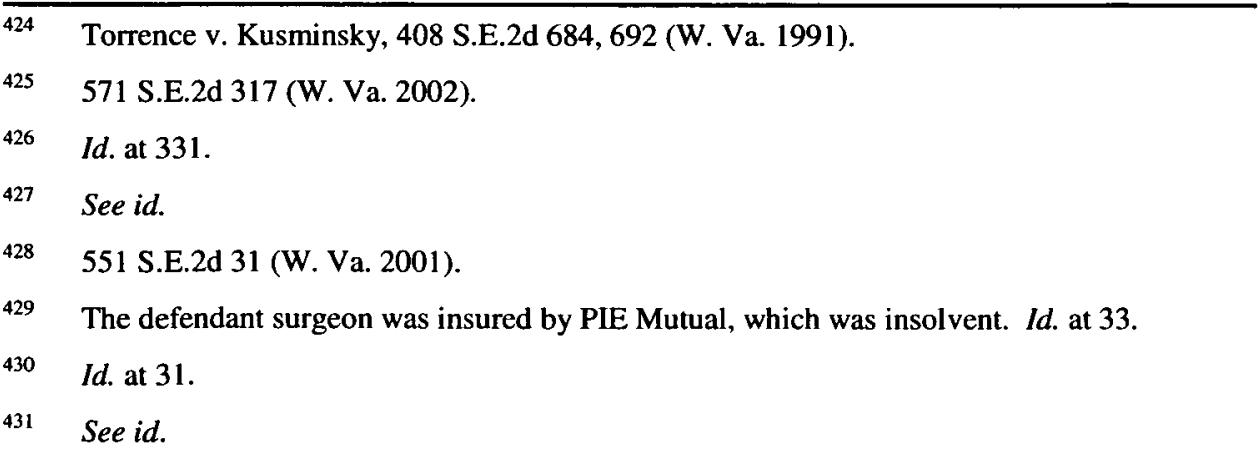


the plaintiff required in television and print advertising. ${ }^{432}$ The plaintiff asserted (as she had by affidavit below) that she "trusted" the hospital to provide appropriate care based upon the kindness of the hospital's staff which led her to believe they were taking care of everything. ${ }^{433}$ Moreover, the plaintiff claimed that she relied upon an "extensive" television and radio advertising campaign by the hospital.

Importantly, the supreme court reversed the summary judgment because the circuit judge's order did not contain any findings related to the advertising liability issue. ${ }^{434}$ The Glover court noted, however, that other courts have held hospitals liable under the doctrine of ostensible agency based on advertising campaigns, and suggested that such a finding is consistent with ostensible agency as defined in the Restatement (Second) of Agency. ${ }^{435}$ The court went on to discuss the hospital's television and print advertising and also noted that it was aware that some hospitals even used billboards. ${ }^{436}$

432 Id.

433 Id. at 34. Whether "kindness" by nurses is a basis for establishing vicarious liability for other health care providers was not addressed by the court. Common sense would suggest that personal kindness by its nurses cannot justify finding a hospital liable for the acts of independent physicians. See Phinney v. Vinson, 605 A.2d 849 (Vt. 1992) (apology for "inadequate" operation not admission of liability).

434 See Glover, 551 S.E.2d at 34. Glover reinforces the need for summary judgment orders to set forth findings of fact. "Although our standard of review for summary judgment remains de novo, a circuit court's order granting summary judgment must set out factual findings sufficient to permit meaningful appellate review. Findings of fact, by necessity, include those facts which the circuit court finds relevant, determinative of the issues and undisputed." Syl. Pt. 3, Scites v. Marcum, 560 S.E.2d 505 (W. Va. 2002) (citing Fayette County Nat'l Bank v. Lilly, 484 S.E.2d 232 (W. Va. 1997)).

435 Glover, 551 S.E.2d at 35. The court stated:

[i]n conjunction with this issue, we note that:

Modern hospitals have spent billions of dollars on marketing to nurture the image that they are full-care modern health facilities. Billboards, television commercials and newspaper advertisements tell the public to look to its local hospital for every manner of care, from the critical surgery and life-support required by a major accident to the minor tissue repairs resulting from a friendly game of softball. These efforts have helped bring the hospitals vastly increased revenue, a new role in daily health care and, ironically, a heightened exposure to lawsuits[.]

Also, [o]ne who represents that another is his servant or other agent and thereby causes a third person justifiably to rely upon the care or skill of such apparent agent is subject to liability to the third person for harm caused by the lack of care or skill of the one appearing to be a servant or other agent as if he were such.

Id. (quotation omitted).

436

Id. 
Justice Davis dissented, pointing out that the "advertising" issue was not relevant as there was no evidence presented that the decedent patient relied on the advertising campaign in choosing the surgeon. ${ }^{437}$ Justice Davis discussed established law that hospitals are not liable for the negligence of physicians on their medical staff absent evidence the patient relied upon the hospital to supply the physician in question. ${ }^{438}$ In a footnote, Justice Davis also expressed disagreement with the use of advertising as a basis of liability because it will either cause all hospitals to stop informing the public of available care, or make them strictly liable for the acts of all physicians on their premises. ${ }^{439}$

In addition to opinions expanding the liability of hospitals for nonemployees for a variety of reasons, the court's decision in Woodrum v. John$\operatorname{son}^{441}$ is highly significant. By holding that a plaintiff can settle with a nonemployee physician and proceed against a hospital that is vicariously liable for the physician, Woodrum will undoubtedly result in hospitals being named in more cases and forced to incur defense and settlement costs even where there are no independent allegations of negligence. Ultimately, it appears a hospital can be forced to go to trial defending a doctor it did not even employ and simply get an offset for the settlement in the same fashion as any other settling defendant. Woodrum's long analysis bears reading, as it is not confined to MPLA cases. $^{442}$

In several decisions, the West Virginia Supreme Court of Appeals has mentioned a cause of action for "negligent credentialing," but the parameters of this claim have yet to be explored in a published opinion. ${ }^{443}$ Since hospitals are

437 Id. at 36-37 (Davis, J., dissenting).

438 Id. at 36 (Davis, J., dissenting) (citing Cross v. Trapp, 294 S.E.2d 446 (W. Va. 1982); Thomas v. Raleigh Gen. Hosp., 358 S.E.2d 222 (W. Va. 1987); Torrence v. Kusminsky, 408 S.E.2d 684 (W. Va. 1991)). Specifically, Justice Davis argued:

Mrs. Glover's affidavit indicating that she may have relied on Hospital advertisements in forming her opinion that the Hospital would provide proper care to Mr. Glover is irrelevant in this case. The affidavit could only be used, at best, to support Mrs. Glover's derivative claim. In order to make such evidence relevant, it had to be submitted by the Estate to demonstrate the advertisement's effect on Mr. Glover's opinion of the Hospital's quality of care.

Glover v. St. Mary's Hosp. of Huntington, 551 S.E.2d 31, 37 (W. Va. 2001) (Davis, J., dissenting).

439 Id. at 37 n.l (Davis, J., dissenting). Not addressed in Glover is the fact that despite the factual differences over agency, the plaintiff did not name an expert. See Goundry v. WetzelSuffle, 568 S.E.2d 5 (W. Va. 2002).

$440 \quad 559$ S.E.2d 908 (W. Va. 2001).

441 See supra notes 400 to 411 for a detailed discussion of Woodrum.

442 See also Matheny v. Fairmont Gen. Hosp., No. 30256, 2002 WL 31746852, at *8 (W. Va. Dec. 6, 2002) (Albright, J., concurring) (restating dissent in Woodrum, 559 S.E.2d at 913).

443 See Andrews v. Reynolds Mem'l Hosp., Inc., 499 S.E.2d 846 (W. Va. 1997); Roberts v. 
expressly included in the MPLA definitions of health care providers and facilities, the issue of credentialing should be one subject to proof by expert testimony in the same fashion as actions against physicians.

West Virginia Code section 30-3C-2 provides immunity for peer review activities, including the credentialing of physicians. ${ }^{444}$ However, while placing liability upon hospitals for failing to police physicians, the supreme court has narrowly construed this immunity. In one decision, Garrison v. Herbert J. Thomas Memorial Hospital Association, ${ }^{445}$ the court, despite the immunity, allowed a physician to sue a West Virginia hospital for tortious interference based on information provided to another hospital for credentialing purposes. ${ }^{446}$ The court has also not hesitated to reverse the Board of Medicine when it impairs or takes away a physician's license. ${ }^{47}$

Hospitals in litigation sometimes face discovery requests for information arising from peer review activities. ${ }^{448}$ Under Rule $26(\mathrm{~b})(1)$ of the West Virginia Rule of Civil Procedure, "[p]arties may obtain discovery regarding any matter, not privileged, which is relevant to the subject matter involved in the pending action." There is a statutory privilege granted to peer review activities by West Virginia Code section 30-3C-3. "Peer review" is defined

Stevens Clinic Hosp., Inc., 345 S.E.2d 791 (W. Va. 1986). See generally Johnson v. Misericordia Cmty. Hosp., 301 N.W.2d 156 (Wis. 1981).

444 See Mahmoodian v. United Hosp. Ctr., Inc., 404 S.E.2d 750, 759 (W. Va. 1991) ("[T]he fact that individuals conducting good-faith health care peer review are statutorily immunized from civil liability for damages evinces a public policy encouraging health care professionals to monitor the competency and professional conduct of their peers in order to safeguard and improve the quality of patient care."); Young v. Saldanha, 431 S.E.2d 669, 673 (W. Va. 1993).

445

438 S.E.2d 6 (W. Va. 1993).

446 Id. at 11. The physician was denied privileges at a Wyoming hospital for failing to reveal a disciplinary action at Thomas Hospital on his application for medical staff privileges. Id. at 9. After unsuccessfully suing that hospital, Garrison v. Bd. of Trustees of Mem'l Hosp., 795 P.2d 190, 191 (Wyo. 1990), he brought suit against Thomas Hospital. Garrison, 458 S.E.2d at 6. The Supreme Court of Appeals of West Virginia reversed the dismissal of the action, holding the physician could bring an action for tortious interference with contractual relations against the hospital if the information provided to the Wyoming hospital was false. Id. at 11.

447 See Webb v. W. Va. Bd. of Med., 569 S.E.2d 225 (W. Va. 2002); W. Va. Bd. of Med. v. Shafer, 535 S.E.2d 480 (W. Va. 2000); State ex rel. Webb v. W. Va. Bd. of Med., 506 S.E.2d 830 (W. Va. 1998).

448 As this article addresses medical professional liability actions, suits by physicians against hospitals arising out of decisions on medical staff appointment or clinical privileges are not examined. However " $[t]$ he decision of a private hospital revoking or otherwise affecting adversely the staff appointment or clinical privileges of a medical staff member will be sustained when, as an element of fair hearing procedures, there is substantial evidence supporting the decision." Syl. Pt. 4, Mahmoodian v. United Hosp. Ctr., Inc., 404 S.E.2d 750 (1991); see also Daily Gazette Co. v. W. Va. Bd. of Med., 352 S.E.2d 66, 72 (W. Va. 1986) ("To the extent that any hospital peer review information is brought before the West Virginia Board of Medicine under West Virginia Code $\$ 30-3-14(0)$ (1986), after probable cause to substantiate the charges is found, the public is entitled to such information."). 
as "the procedure for evaluation by health care professionals of the quality and efficiency of services ordered or performed by other health care professionals." ${ }^{449}$ Peer review is performed by "review organizations," defined in West Virginia Code section 30-3C-1:

any committee or organization engaging in peer review, including a hospital utilization review committee, a hospital tissue committee, a medical audit committee, a health insurance review committee, a hospital plan corporation review committee, a professional health service plan review committee or organization, a dental review committee, a physicians' advisory committee, a podiatry advisory committee, a nursing advisory committee, any committee or organization established pursuant to a medical asșistance program, and any committee established by one or more state or local professional societies or institutes, to gather and review information relating to the care and treatment of patients for the purposes of (i) evaluating and improving the quality of health care rendered; (ii) reducing morbidity or mortality; or (iii) establishing and enforcing guidelines designed to keep within reasonable bounds the cost of health care. It shall also mean any hospital board committee, or organization reviewing the professional qualifications or activities of its medical staff or applicants for admission thereto, and any professional standards review organizations established or required under state or federal statutes or regulations. ${ }^{450}$

West Virginia Code section 30-3C-3 protects the peer review process from discovery in any civil action, providing:

The proceedings and record of a review organization shall be confidential and privileged and shall not be subject to subpoena or discovery proceedings or be admitted as evidence in any civil action arising out of the matters which are subject to evaluation and review by such organization and no person who is in attendance at a meeting of such organization shall be permitted or required to testify in any such civil action as to any evidence or other matters produced or presented during the proceedings of such organization or as to any findings, recommendations, evaluations, opinions or other actions of such organization or any members thereof: Provided, That information, documents or records otherwise available from original sources are not to

Id. 
be construed as immune from discovery or use in any civil action merely because they were presented during such organization, nor should any person who testifies before such organization or who is a member of such organization be prevented from testifying as to a matter within his knowledge, but the witness shall not be asked about his testimony before such an organization or opinions formed by him as a result of said organization hearings .... ${ }^{451}$

The Supreme Court of Appeals of West Virginia has consistently held "[t]he enactment of [West Virginia] Code [section] 30-3C-1 to -3 (1993) clearly evinces a public policy encouraging health care professionals to monitor the competency and professional conduct of their peers in order to safeguard and improve the quality of patient care." arises from the belief that without an assurance of confidentiality, "physicians [will be] reluctant to sit on peer review committees and engage in frank evaluations of their colleagues." 453 "[C]onstructive professional criticism cannot occur in an atmosphere of apprehension that one doctor's suggestion will be used as a denunciation of a colleague's conduct in a malpractice suit." ${ }^{454}$ In State ex rel. Shroades $v$. Henry, ${ }^{455}$ the court stated that "[t]he peer review privilege represents a legislative choice between medical staff candor and the plaintiff's access to evidence."

The peer review privilege protects the "records and proceedings" of review organizations, but not documents otherwise available from original sources:

The language of the statute grants a privilege to all the records and proceedings of a review organization, but no privilege attaches to information, documents or records considered by a review organization if the material is "otherwise available from original sources." Material that originates in a review organization remains privileged even if held by a non-review organization and material that originates in a non-review organization does not become privileged after presentation to a review or-

$451 \quad$ Id. $\$ 30-3 C-3$ (2002).

452 Syl. Pt. 6, State ex rel. Charles Town Gen. Hosp. v. Sanders, 556 S.E.2d 85 (W. Va. 2001) (quoting Syl. Pt. 2, Young v. Saldanha, 431 S.E.2d 669 (1993)); see also Daily Gazette Co. v. W. Va. Bd. of Med., 352 S.E.2d 66 (W. Va. 1986).

453 Young, 431 S.E.2d at 673 (internal quotations omitted).

454 Daily Gazette Co., 352 S.E.2d at 72 n.12 (quoting Bredice v. Doctors Hosp., Inc., 50 F.R.D. 249, 249-50 (D.D.C. 1970)).

455421 S.E.2d 264 (W. Va. 1992).

456

Id. at 268. 
ganization. Therefore, material sought from a review organization is privileged; however if material is sought from a nonreview organization, the origin of the document determines if it is privileged. ${ }^{457}$

The party asserting the peer review privilege has the burden of demonstrating that it applies. ${ }^{458}$ Blanket assertions of privilege are generally not sufficient to invoke the peer review privilege. ${ }^{459}$ The fact that a physician has obtained peer review documents in a suit over the termination of his privileges by a hospital does not establish a waiver allowing the documents' discovery in a civil action against the physician. ${ }^{460}$

"The determination of which materials are privileged under [West Virginia] Code [section] 30-3C-1 [1975] et seq. is essentially a factual question," ${ }^{, 461}$ which first requires an examination of whether the committee from whom information is sought is a "review organization" within the meaning of statute. ${ }^{462}$ The circuit court should first examine the hospital by-laws or other documents ${ }^{463}$ to determine if the committee or organization involved is a review organization as defined in West Virginia Code section 30-3C-1. ${ }^{464}$ If the bylaws do not clearly specify that the committee was engaging in peer review, the party asserting the privilege has the burden of presenting additional evidence and information to the court. ${ }^{465}$

Once the circuit court determines the committee was engaged in peer

\author{
$457 \quad$ Id. at 269 (footnote omitted). \\ $458 \quad$ Id. at 265 Syl. Pt. 2. \\ $459 \quad$ Id. at 268 \\ 460 See Young v. Saldahna, 431 S.E.2d 669 (W. Va. 1993). \\ 461 Id. at 670 Syl. Pt. 1 . \\ 462 See Sanders, 556 S.E.2d at 93.
}

463 As recognized by section 30-3C-1, there are "review organizations" other than those created by hospitals, such as "any committee established by one or more state or local professional societies or institutes ...." W. VA. CoDE § 30-3C-1. For example, the Joint Commission on Accreditation of Hospital Organizations ("JCAHO") "establishes standards and conducts voluntary accreditation programs for West Virginia hospitals ...." Daily Gazette Co., Inc., v. W. Va. Bd. of Med., 352 S.E.2d 66, 71n.10 (W. Va. 1986). Surveys by the JCAHO have been held to be "peer review" not subject to discovery. Niven v. Siqueira, 487 N.E.2d 937, 942 (Ill. 1985) (JCAHO accreditation manual used to show materials were gathered to improve quality control and patient care protected by peer review act); see also Variety Children's Hosp. v. Mishler, 670 So. 2d 184, 186 n.3 (Fla. Dist. Ct. App. 1996) (noting that JCAHO surveys not discoverable); Humana Hosp. Corp., Inc. v. Spears-Petersen, 867 S.W.2d 858, 862 (Tex. Ct. App. 1993) (noting that JCAHO accreditation reports held confidential). The party asserting the privilege, therefore, should submit evidence demonstrating the purpose and function of the review committee in question.

Henry, 421 S.E.2d at 270.

465

Id. 
review, it must determine whether the challenged documents come within the privilege, which protects the "proceedings and record" of the review organization. ${ }^{466}$ The party asserting the privilege has to prepare a privilege $\log$, identifying the document name, date, custodian, source and reason for creation. ${ }^{467}$ Identification of documents does not breach the privilege afforded by section 30-3C-1. Where necessary, the court can review in camera the documents argued to be undiscoverable. ${ }^{468}$ Where the circuit court rules the material is discoverable, a petition for a writ of prohibition is appropriate. $^{469}$

In State ex rel. Sanders $v$. Charlestown Hospital, ${ }^{470}$ the court applied the aforementioned analysis and held that a physician's application for privileges was protected. The court found that the hospital's credentialing committee was a "review organization" because it was responsible under the hospital's by-laws for considering candidates for staff privileges or credentials. ${ }^{41}$ The peer review privilege therefore applied to protect the physician's application for privileges from discovery. ${ }^{472}$ Similarly, in Young $v$. Saldahna, ${ }^{473}$ the court held that records of a hospital's actions against the privileges of a physician were protected from discovery in a malpractice case, even though the physician had obtained them in a separate action against the hospital over the termination of his privileges. ${ }^{474}$

On a related issue, the court has held that hospital incident reports are not protected from discovery by the "work product" privilege. In State ex rel. United Hosp. Center, Inc. v. Bedell, ${ }^{475}$ the court held a hospital's incident report was not protected by the attorney client privilege or the work product doctrine. Examining the hospital's policies and deposition testimony of witnesses, the court concluded that " $[t]$ he incident report prepared, in this case, . . . immediately after [the patient] fell in the emergency room was completed, not for purposes of litigation, but in the ordinary course of the hospital's business."

\footnotetext{
466 W. VA. CODE $§ 30-3 C-3(2002)$.

467 Id.; see also Feathers v. W. Va. Bd. of Med., 562 S.E.2d 488, 497 (W. Va. 2001).

468 Henry, 421 S.E. $2 \mathrm{~d}$ at 270.

469 See State ex rel. United Hosp. Ctr., Inc. v. Bedell, 484 S.E.2d 199, 207 (W. Va. 1997).

$470 \quad 556$ S.E.2d $85(2001)$.

$471 \quad$ Id. at 92.

472 Sanders, 556 S.E.2d at $93-94$.

473431 S.E.2d 669 (W. Va. 1993).

474 Id. at 675-76.

475484 S.E.2d 199 (W. Va. 1997).

476 Id. at 213 . The court found the attorney-client privilege did not apply because the record did not establish the nurse preparing the report contemplated an attorney-client relationship when
} 
however, was subject to the protection under the work product doctrine, except that it was waived when the counsel was produced for deposition as a designated corporate representative. ${ }^{477}$ Bedell does not address whether an incident report can be protected by the peer review privilege, as the issue was not argued in the circuit court and therefore not considered on appeal. ${ }^{478}$

\section{DAMAGES}

The MPLA limits non-economic loss to one million dollars. ${ }^{479}$ According to West Virginia Code section 55-7B-2(g), non-economic losses "include[] but [are] not limited to pain, suffering, mental anguish and grief." The "cap" on non-economic loss is constitutional, having survived challenges in two cases. ${ }^{480}$ The cap does not limit economic losses. ${ }^{481}$ The trial court has discretion as to whether to instruct the jury about the limitations. ${ }^{482}$

Arguably, the cap on non-economic loss applies per occurrence, not per plaintiff. In Robinson v. Charleston Area Medical Center, Inc. ${ }^{483}$ the court applied the cap to reduce non-economic loss awards to one million dollars. The first awards reduced were the damages awarded to the parents of the brain damaged child for loss of consortium. ${ }^{444}$ Then, the court reduced the child's award to one million dollars. ${ }^{485}$ Although Robinson strongly suggests that the cap is an overall limit on non-economic loss, the court has not, in a syllabus point, decided whether it applies per defendant, or as an overall limit. ${ }^{486}$ The court also has not articulated how the cap applies in agency situations (for example, where a non-employee physician is alleged to be agent of hospital).

she submitted the report. Id. at 209.

477 Id. at 213-14.

$478 \quad$ Id. at 208 n.9.

479 W. VA. CODE $§ 55-7 B-8(2000)$.

480 Verba v. Ghaphery, 552 S.E.2d 406 (W. Va. 2001); Robinson v. Charleston Area Med. Ctr., Inc., 414 S.E.2d 877 (W. Va. 1992).

481 See Andrews v. Reynolds Mem'l Hosp., 499 S.E.2d 846 (W. Va. 1997) (affirming jury award including $\$ 1.7$ million dollars for lost future income for a deceased infant; rejecting argument that the award was speculative).

482 W. VA. CODE $§ 55-7 B-8(2000)$.

$483 \quad 414$ S.E.2d 877 (W. Va. 1992).

$484 \quad$ Id. at 889.

$485 \quad$ Id.

486 See Etheridge v. Med. Ctr. Hosp., 376 S.E.2d 525 (Va. 1989) (holding damages cap applies per case, not per defendant); Rhyne v. K-Mart Corp., 562 S.E.2d 82 (N.C. 2002) (North Carolina statute capping punitive damages is constitutional, and the limitation applies per plaintiff, not per defendant); $c f$. Frye v. Future Inns of America-Huntington, Inc., 566 S.E.2d 237 (W. Va. 2002) (holding incidental damages under Human Rights Act applies per case, not per respondent). 
Where the jury's verdict form is unclear as to the amount of noneconomic damages awarded, the court will not attempt to sort it out to apply the cap. In Gerver $v$. Benavides, ${ }^{487}$ the supreme court refused to apply the cap to reduce a $\$ 2$ million dollar verdict because the jury verdict form mixed special and general damages. To preserve the applicability of the cap, the defendant must submit a verdict form or ask for special interrogatories that clearly separate economic and non-economic damages. ${ }^{488}$ Under Gerver, confusion may result in the cap not being applied. ${ }^{489}$

Consistent with Gerver, the verdict form does not have to contain multiple lines for different types of non-economic loss. The simplest way to comply with Rule 49(b) of the West Virginia Rules of Civil Procedure is to allow the jury to assign non-economic loss consistent with the court's instructions. Rule 49(b), which governs the use of jury interrogatories used in conjunction with a general jury verdict form, states that " $[t]$ he court may submit to the jury, together with appropriate forms for a general verdict, written interrogatories upon one or more issues of fact the decision of which is necessary to a verdict.",490

By its terms, Rule 49(b) limits the jury interrogatories to issues of fact "the decision of which is necessary to a verdict." with respect to damages is appropriate when it is necessary to separate the damage elements. ${ }^{492}$ In Gebhardt v. Smith, ${ }^{493}$ the jury was instructed to return a general verdict and set forth the damages for medical bills and lost income. The form also required the jury to itemize damages in the following areas:

(1) "pain and suffering experienced to date, if any"; (2) "pain and suffering to be experience in the future if any"; and (3) "loss of enjoyment of life, including the inability to engage in

$487 \quad 530$ S.E.2d 701 (W. Va. 1999).

$488 \quad$ Id. at 708 .

489 An interesting comparison to the approach taken in Gerver $v$. Benavides is seen in Beard $v$. Lim, 408 S.E.2d 772 (W. Va. 1991). In Beard, the circuit court applied prejudgment interest to a general verdict, refusing to sort out the items of pecuniary damages to which prejudgment interest applies. Id. at 773. The supreme court reversed, stating that "when the lawyers and the trial court can sort out the parts of a judgment on which interest should be added, even without special interrogatories, the trial court should do so." Id. at 777 (quoting Miller v. Monongahela Power Co., 403 S.E.2d 406, 416 (W. Va. 1991)). The Beard approach is more in keeping with the public policy of limiting non-economic loss expressed by the legislature in enacting the non-economic damages cap.

490 W. VA. R. Civ. P. 49(b).

$491 \quad$ Id.

492 See Grove v. Myers, 382 S.E.2d 536, 542 (W. Va. 1989) (noting that since prejudgment interest is only recoverable on special damages, "a special interrogatory should be submitted to the jury for it to designate the amount of special or liquid damages"). 
normal pursuits and activities and permanent disability and disfigurement." ${ }^{494}$

The Supreme Court of Appeals commented on deficiencies in this form:

It is not clear from the record why the jury was requested to itemize the general verdict form in the manner set forth in the text of the opinion. Such specificity in a personal injury case such as this appears to be limited value. It may, in some cases, cause error by focusing on the itemized categories and the potential inconsistencies contained therein (i.e., a jury could be presented evidence of substantial pain and suffering in the past and of only a limited likelihood of pain and suffering in the future, and nonetheless grant more damages for future pain and suffering). The potential for error by itemizations such as this in such a personal injury case is greater than in verdicts of a more general nature. ${ }^{495}$

\section{CONCLUSION}

Medical professional liability actions in West Virginia present many complex and unique legal issues in addition to the difficult task of mastering the medicine involved. Hopefully, this article highlighted some of these issues for the West Virginia practitioner based on the present statutory scheme and case law. To be sure, the coming months will see new statutes and legal decisions which will further impact practitioners in this area.

\footnotetext{
$494 \quad$ Id. at 278 .
}

495 Id. at n.3. 